\title{
MAPEAMENTO DA VARIABILIDADE ESPACIAL DAS PLANTAS DANINHAS COM A UTILIZAÇÃO DE FERRAMENTAS DA AGRICULTURA DE PRECISÃO
}

\section{LUCIANO SHOZO SHIRATSUCHI}

Dissertação apresentada à Escola Superior de Agricultura "Luiz de Queiroz", Universidade de São Paulo, para obtenção do título de Mestre em Agronomia, Área de Concentração: Fitotecnia.

PIRACICABA

Estado de São Paulo - Brasil

Outubro - 2001 


\section{MAPEAMENTO DA VARIABILIDADE ESPACIAL DAS PLANTAS DANINHAS COM A UTILIZAÇÃO DE FERRAMENTAS DA AGRICULTURA DE PRECISÃO}

\section{LUCIANO SHOZO SHIRATSUCHI}

Engenheiro Agrônomo

Dissertação apresentada à Escola Superior de Agricultura "Luiz de Queiroz", Universidade de São Paulo, para obtenção do título de Mestre em Agronomia, Área de Concentração: Fitotecnia.

PIRACICABA

Estado de São Paulo - Brasil

Outubro - 2001 


\section{Dados Internacionais de Catalogação na Publicação (CIP) DIVISĀO DE BIBLIOTECA E DOCUMENTAÇÃO - ESALQ/USP}

\footnotetext{
Shiratsuchi, Luciano Shozo

Mapeamento da variabilidade espacial das plantas daninhas com a utilização de ferramentas da agricultura de precisão / Luciano Shozo Shiratsuchi. - - Piracicaba, 2001.

96 p. : il.
}

Dissertação (mestrado) - - Escola Superior de Agricultura Luiz de Queiroz, 2001. Bibliografia.

1. Agricultura de precisão 2. Banco de semente 3. Controle químico 4. Geoprocessamento 5. GPS 6. Mapeamento 7. Planta daninha 8. SIG 9. Variabilidade espacial l. Título

CDD 632.58

"Permitida a cópia total ou parcial deste documento, desde que citada a fonte - O autor" 


\section{DEDICO}

À meus queridos pais, Mauro e Lúcia, pela filosofia de vida e às pessoas que colaboraram direta ou indiretamente na minha vida pessoal e profissional. 


\section{AGRADECIMENTOS}

- $\quad$ Agradeço à DEUS por iluminar meu caminho.

- Aos meus queridos pais, Mauro e Lúcia, por terem me guiado e me darem a melhor herança que um filho pode ter que é a educação.

- À minha admirável e estimada irmã, Giovana, pelo elo familiar que temos.

- Especialmente à minha querida Simone que me acompanha, passo a passo, me aconselhando e assegurando em tudo que faço.

- Ao Prof. Dr. Pedro Jacob Christoffoleti, que além da orientação e filosofia de trabalho que me passou, também é um grande amigo.

- $\quad$ Ao Prof. Dr. José Paulo Molin pela colaboração e atenção durante todas etapas.

- Aos Professores Doutores Durval Dourado Neto, Maria Cristina Stolf Nogueira e Ricardo Victoria Filho, pela convivência e apoio durante minha vida acadêmica.

- À Fundação de Amparo à Pesquisa do Estado de São Paulo (FAPESP) pela bolsa de estudos concedida e apoio recebido.

- Ao Departamento de Produção Vegetal e Departamento de Engenharia Rural da Universidade de São Paulo, Escola Superior de Agricultura "Luiz de Queiroz" (USP/ESALQ), pela disponibilidade de equipamentos e serviços. 
- Aos amigos Márcio Cortucci, Jorge Murilo Suguisawa, Marcelo Nicolai, Danilo Suguisawa, Raimundo Leite, Daniel Medeiros, Liliane Suguisawa, Luis Fernando Tamassia, Aline Maia, Leonardo Menegatti, Silvana da Silva Cardoso, Danilo Alves, Clodoaldo Almeida, José Luis de Marchi e Gustavo Cechini.

- Aos Professores Doutores Lawrence W. Lass e Donald Thill da Universidade de Idaho, Estados Unidos da América do Norte, pela oportunidade de intercâmbio, aprendizado profissional e pessoal.

- Aos funcionários do Departamento de Produção Vegetal pelo apoio e convivência, principalmente à Ony, Aparecido, Luiz, Helena, Betty, Célia e Serrano.

- À Faculdade de Zootecnia e Engenharia de Alimentos da Universidade de São Paulo (USP/FZEA) na parceria da área experimental para a realização do experimento.

- Ao Engenheiro Agrônomo Eduardo Ferraz pelo apoio, convívio e amizade.

- Aos funcionários da Faculdade de Zootecnia e Engenharia de Alimentos, principalmente ao José, Israel, Jacomino e Meneguini.

- À empresa “John Deere” pelo apoio em equipamentos e pessoal.

- Aos funcionários da Biblioteca Central da Universidade de São Paulo, Escola Superior de Agricultura "Luiz de Queiroz" (USP/ESALQ), principalmente à Eliana e Silvia. 


\section{SUMÁRIO}

Página

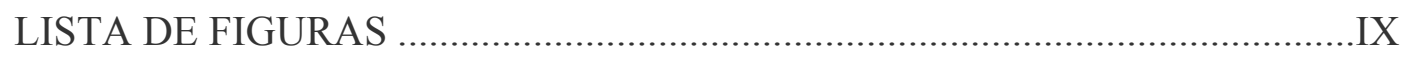

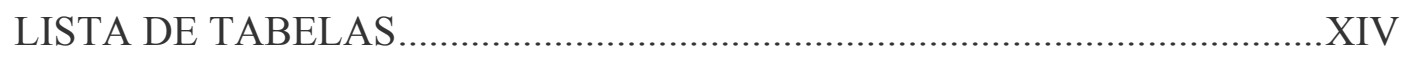

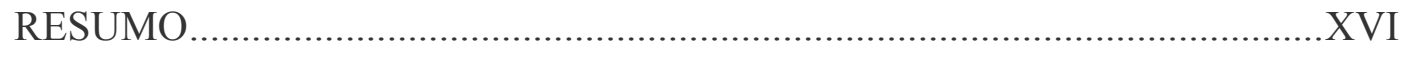

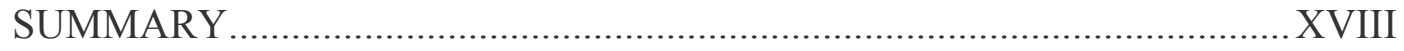

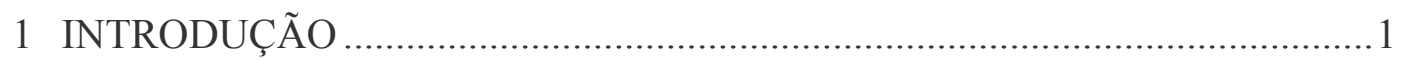

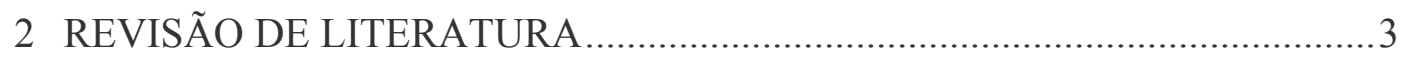

2.1 Agricultura de precisão: Definição e breve histórico.......................................... 3

2.2 Sistema de posicionamento global (GPS) ...................................................

2.3 Sistemas de Informação Geográfica (SIG ou GIS) ........................................

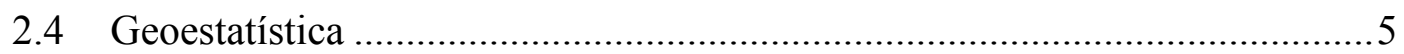

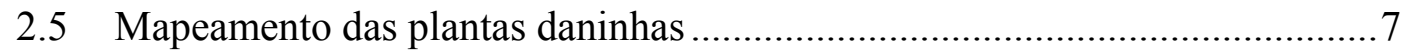

2.5.1 Mapeamento pelo método de contorno das infestações ....................................8

2.5.2 Mapeamento pelo método de amostragens em grade ("grid")....................... 10

2.5.3 Mapeamento das plantas daninhas na colheita da cultura................................11

2.5.4 Mapeamento do banco de sementes das plantas daninhas .............................12

2.6 Sistemas de aplicação localizada de herbicidas ................................................15

2.6.1 Aplicação localizada de herbicidas baseada em mapas ..................................15

2.6.2 Aplicação localizada em tempo real ("Real time”)........................................16

3 MAPEAMENTO DA VARIABILIDADE ESPACIAL E TEMPORAL DO BANCO DE SEMENTES DAS PLANTAS DANINHAS .................................18

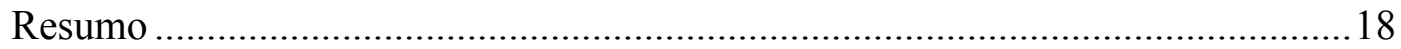


Summary......

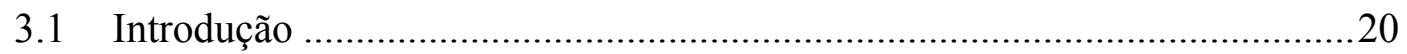

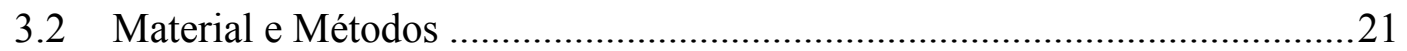

3.2.1 Local e condições gerais do experimento. ……………………………......21

3.2.2 Método de amostragem do banco de sementes .............................................21

3.2.3 Procedimentos de determinação do banco de sementes.................................22

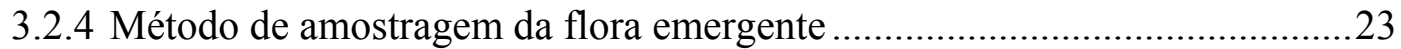

3.2.5 Equipamentos e softwares utilizados ........................................................24

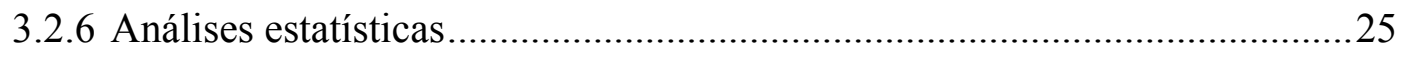

3.2.7 Análise espacial da população das plantas daninhas......................................26

3.2.8 Correlações entre o banco de sementes e a flora emergente ...........................27

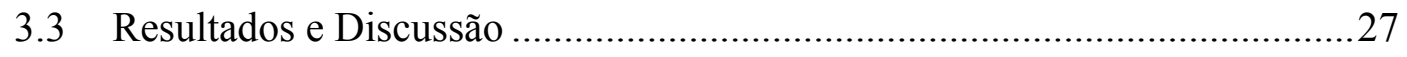

3.3.1 Emergência do banco de sementes e análises preliminares ............................27

3.3.2 Estrutura espacial da população das plantas daninhas .....................................32

3.3.3 Análises dos semivariogramas das plantas daninhas .....................................33

3.3.4 Correlações entre o banco de sementes e a flora emergente ...........................45

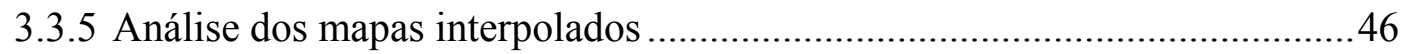

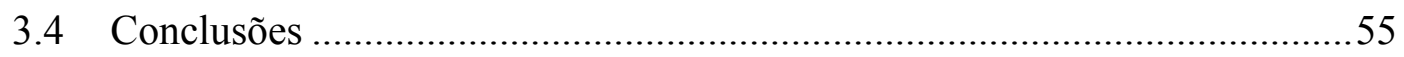

4 MAPEAMENTO DA DISTRIBUIÇÃO ESPACIAL DA INFESTAÇÃO DO CAPIM COLONIÃO (Panicum maximum Jacq.) DURANTE A COLHEITA

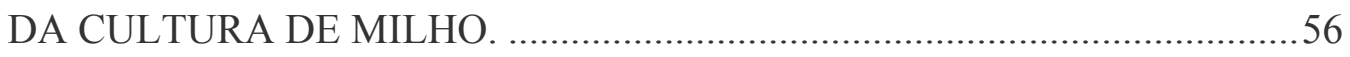

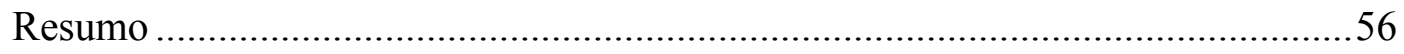

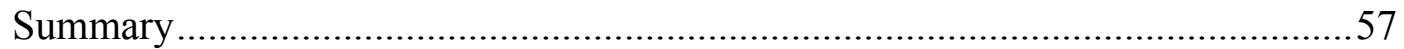

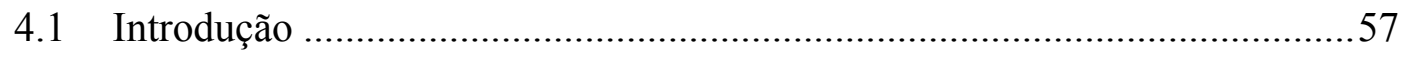

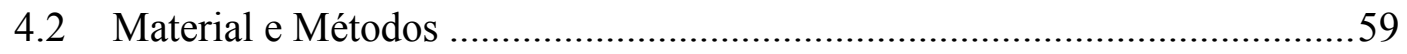

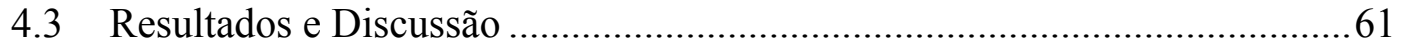

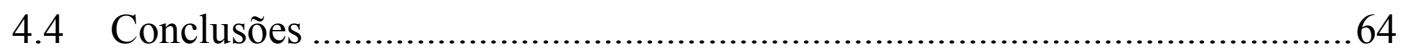


5 APLICAÇÃO LOCALIZADA DE HERBICIDAS EM PÓS-EMERGÊNCIA

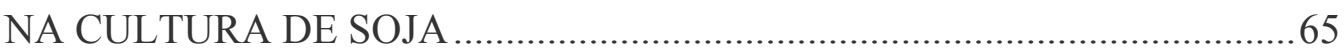

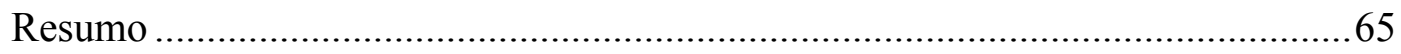

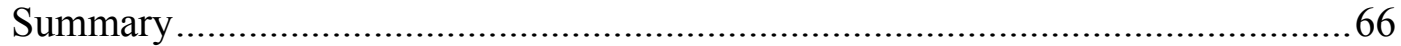

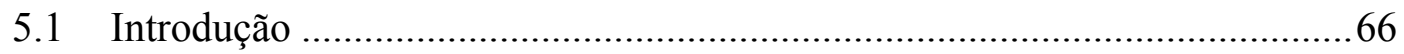

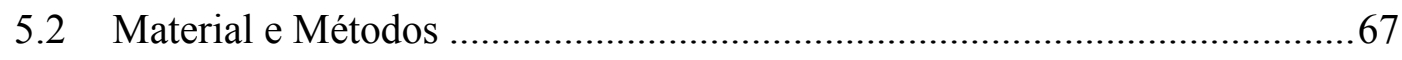

5.2.1 Pulverização localizada pós-emergente. ...................................................69

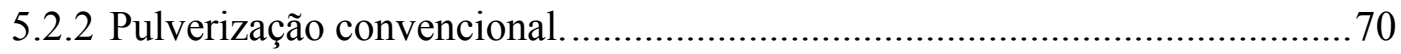

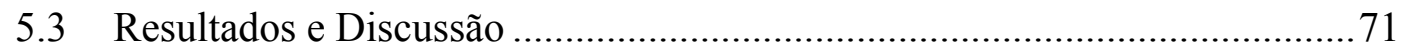

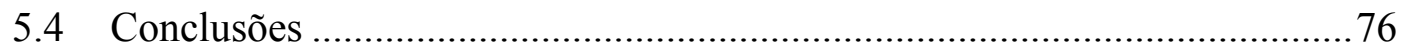

6 APLICAÇÃO LOCALIZADA DE HERBICIDAS EM PRÉ-EMERGÊNCIA BASEADA EM MAPAS DE BANCO DE SEMENTES...............................78

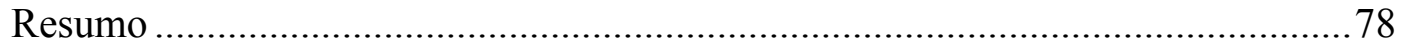

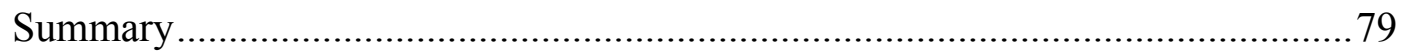

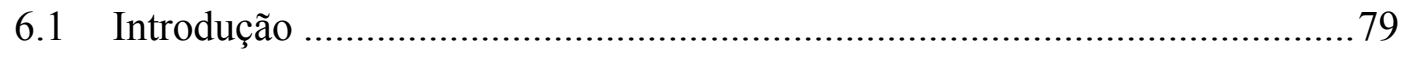

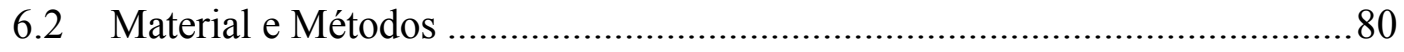

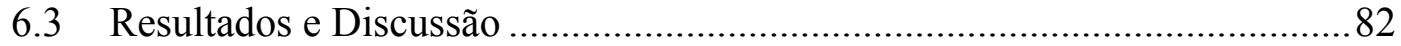

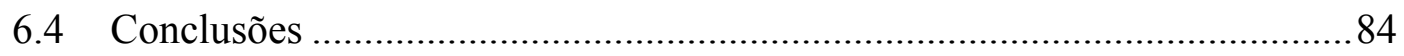

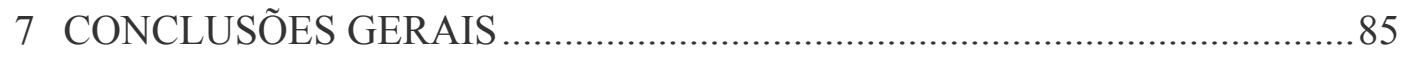

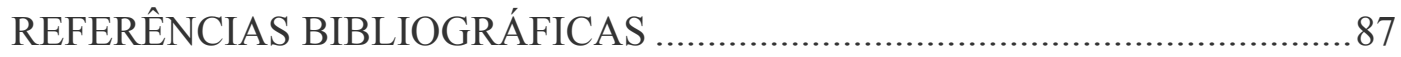




\section{LISTA DE FIGURAS}

Página

1 Gráfico mostrando os principais parâmetros de um semivariograma........................6

2 Esquema de uma aplicação localizada de herbicida baseada na detecção em tempo real, adaptado de Tian et al. (1999).

3 Semivariograma ajustado para a flora emergente (2001) de Alternanthera tenellla (A) e seu respectivo gráfico de dispersão da validação cruzada (B) realizada para os dados resultantes da interpolação por krigagem em 2001 33

4 Semivariograma ajustado para o banco de sementes (2001) de Alternanthera tenellla (A) e seu respectivo gráfico de dispersão da validação cruzada (B) realizada para os dados resultantes da interpolação por krigagem em 2001 .34

5 Semivariograma ajustado para a flora emergente (2001) de Panicum maximum (A) e seu respectivo gráfico de dispersão da validação cruzada (B) realizada para os dados resultantes da interpolação por krigagem em 2001. .36

6 Semivariograma ajustado para o banco de sementes (2001) de Panicum maximum (A) e seu respectivo gráfico de dispersão da validação cruzada (B) realizada para os dados $\begin{array}{lllll}\text { resultantes da interpolação em } & \text { por } & \text { krigagem } & \text { em }\end{array}$ 2001 .36 
7 Semivariograma ajustado para a flora emergente (2001) de Ageratum conyzoides (A) e seu respectivo gráfico de dispersão da validação cruzada (B) realizada para os dados resultantes da interpolação por krigagem em 2001 38

8 Semivariograma ajustado para o banco de sementes (2001) de Ageratum conyzoides (A) e seu respectivo gráfico de dispersão da validação cruzada (B) realizada para os dados resultantes da interpolação por krigagem em 2001

9 Semivariograma ajustado para a flora emergente (2001) de Commelina benghalensis (A) e seu respectivo gráfico de dispersão da validação cruzada (B) realizada para os dados resultantes da interpolação por krigagem em 2001

10 Semivariograma ajustado para o banco de sementes (2001) de Commelina benghalensis (A) e seu respectivo gráfico de dispersão da validação cruzada (B) realizada para os dados resultantes da interpolação por krigagem em 2001

11 Semivariograma ajustado para o banco de sementes (2001) das plantas monocotiledôneas (A) e seu respectivo gráfico de dispersão da validação cruzada (B) realizada para os dados resultantes da interpolação por krigagem em 2001 .42

12 Semivariograma ajustado para a flora emergente (2001) das classes das plantas daninhas dicotiledôneas (A) e seu respectivo gráfico de dispersão da validação cruzada (B) realizada para os dados resultantes da interpolação por krigagem em 2001 .43

13 Mapa interpolado por krigagem do banco de sementes coletado em junho de 2000 de Alternanthera tenella representado em células de $10 \times 10 \mathrm{~m}$, dividido em três classes de infestações de sementes. $\mathrm{m}^{-2}$.

14 Mapa interpolado por krigagem do banco de sementes coletado em janeiro de 2001 de Alternanthera tenella representado em células de $10 \times 10 \mathrm{~m}$, dividido em três classes de infestações de sementes. $\mathrm{m}^{-2}$ 
15 Mapa interpolado por krigagem da flora emergente em abril de 2001 de Alternanthera tenella representado em células de $10 \times 10 \mathrm{~m}$, dividido em três classes de infestações de plantas. $\mathrm{m}^{-2}$.

16 Mapa interpolado por krigagem de do banco de sementes coletado em junho de 2000 de Panicum maximum representado em células de $10 \times 10 \mathrm{~m}$, dividido em três classes de infestações de sementes. $\mathrm{m}^{-2}$. .50

17 Mapa interpolado por krigagem do banco de sementes coletado em janeiro de 2001 de Panicum maximum representado em células de $10 \times 10 \mathrm{~m}$, dividido em três classes de infestações de sementes. $\mathrm{m}^{-2}$. .50

18 Mapa interpolado por krigagem da flora emergente em abril de 2001 de Panicum maximum representado em células de $10 \times 10$ m, dividido em três classes de infestações de plantas. $\mathrm{m}^{-2}$.

19 Mapa interpolado por krigagem de do banco de sementes coletado em junho de 2000 de Ageratum conyzoides representado em células de $10 \times 10$ m, dividido em três classes de infestações de sementes. $\mathrm{m}^{-2}$.

20 Mapa interpolado por krigagem do banco de sementes coletado em janeiro de 2001 de Ageratum conyzoides representado em células de $10 \times 10 \mathrm{~m}$, dividido em três classes de infestações de sementes. $\mathrm{m}^{-2}$.....

21 Mapa interpolado por krigagem da flora emergente em abril de 2001 de Ageratum conyzoides representado em células de 10 x 10 m, dividido em três classes de infestações de plantas. $\mathrm{m}^{-2}$.

22 Mapa interpolado por krigagem de do banco de sementes coletado em junho de 2000 Commelina benghalensis representado em células de $10 \times 10 \mathrm{~m}$, dividido em três classes de infestações de sementes. $\mathrm{m}^{-2}$. .52

23 Mapa interpolado por krigagem do banco de sementes coletado em janeiro de 2001 de Commelina benghalensis representado em células de $10 \times 10 \mathrm{~m}$, dividido em três classes de infestações de sementes. $\mathrm{m}^{-2}$. 
24 Mapa interpolado por krigagem da flora emergente em abril de 2001 de Commelina benghalensis representado em células de $10 \times 10 \mathrm{~m}$, dividido em três classes de infestações de plantas. $\mathrm{m}^{-2}$.

25 Mapa interpolado por krigagem de do banco de sementes coletado em junho de 2000 de plantas monocotiledôneas representado em células de $10 \times 10 \mathrm{~m}$, dividido em três classes de infestações de sementes. $\mathrm{m}^{-2}$.

26 Mapa interpolado por krigagem do banco de sementes coletado em janeiro de 2001 de plantas monocotiledôneas representado em células de $10 \times 10 \mathrm{~m}$, dividido em três classes de infestações de sementes. $\mathrm{m}^{-2}$

27 Mapa interpolado por krigagem da flora emergente em abril de 2001 de plantas monocotiledôneas representado em células de 10 x 10 m, dividido em três classes de infestações de plantas. $\mathrm{m}^{-2}$

28 Mapa interpolado por krigagem de do banco de sementes coletado em junho de 2000 de plantas dicotiledôneas representado em células de $10 \times 10 \mathrm{~m}$, dividido em três classes de infestações de sementes. $\mathrm{m}^{-2}$

29 Mapa interpolado por krigagem do banco de sementes coletado em janeiro de 2001 de plantas dicotiledôneas representado em células de $10 \times 10 \mathrm{~m}$, dividido em três classes de infestações de sementes. $\mathrm{m}^{-2}$.

30 Mapa interpolado por krigagem da flora emergente em abril de 2001 de plantas dicotiledôneas representado em células de $10 \times 10 \mathrm{~m}$, dividido em três classes de infestações de plantas. $\mathrm{m}^{-2}$. .54

31 Vista das reboleiras de alta infestação de capim colonião no momento da colheita .60

32 Mapa das marcações de alta infestação de capim colonião feitas durante e após a colheita do milho.

33 Densidade média de plantas daninhas por espécie (plantas.m²). 
34 Mapas de densidade de plantas daninhas na área A antes (1) e após (2) a aplicação

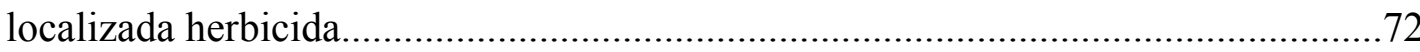

35 Mapas da densidade de plantas daninhas na área B antes (1) e após (2) a aplicação localizada pós emergente........................................................................................75

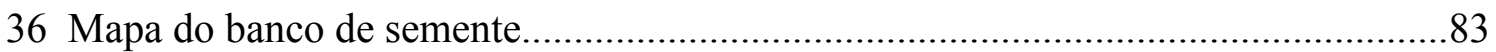

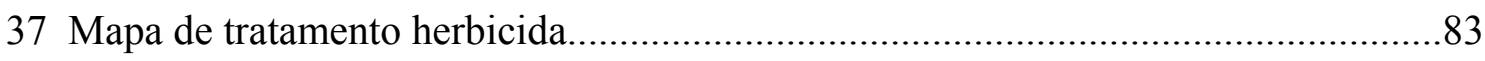




\section{LISTA DE TABELAS}

Página

1 Densidade do banco de sementes 2000 (BS00) e 2001(BS01) e emergência da flora daninha(F01) na cultura de soja plantada em março de 2001

2 Estatística descritiva dos dados de contagem do banco de sementes 2000 (A), do

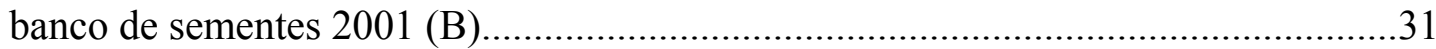

3 Estatística descritiva dos dados de contagem da flora emergente 2001

4 Parâmetros dos semivariogramas ajustados ao modelo esférico e validação cruzada realizada pelos dados interpolados para Alternanthera tenella

5 Parâmetros dos semivariogramas ajustados ao modelo esférico e validação cruzada realizada pelos dados interpolados para Panicum maximum.

6 Parâmetros dos semivariogramas ajustados ao modelo esférico e validação cruzada realizada pelos dados interpolados para Ageratum conyzoides. 39

7 Parâmetros dos semivariogramas ajustados ao modelo esférico e validação cruzada realizada pelos dados interpolados para Commelina benghalensis.....

8 Parâmetros dos semivariogramas ajustados ao modelo esférico e validação cruzada realizada pelos dados interpolados para as classes mono e dicotiledôneas. 
9 Correlação de Spearman rank como medida de comparação do banco de sementes coletado em junho de 2000 em janeiro de 2001 com a Flora emergente em abril de 2001 45

10 Área de infestação considerada alta ( $80 \%$ de cobertura) de capim colonião (Panicum maximum) e o tempo utilizado para levantamento da área após a colheita do milho. .62

11 Doses dos herbicidas utilizados na aplicação localizada .70

12 Total de produto herbicida gasto na área experimental A utilizando aplicação localizada e convencional de herbicidas.

13 Proporção de infestação da área A dependendo da densidade de plantas .73

14 Total de produto herbicida gasto na área experimental B utilizando aplicação localizada e convencional de herbicidas

15 Proporção de infestação da área B dependendo da densidade de plantas...................75

16 Avaliação da eficácia e seletividade herbicida do experimento...............................76 


\title{
MAPEAMENTO DA VARIABILIDADE ESPACIAL DAS PLANTAS DANINHAS COM A UTILIZAÇÃO DE FERRAMENTAS DA AGRICULTURA DE PRECISÃO
}

\author{
Autor: LUCIANO SHOZO SHIRATSUCHI \\ Orientador: Prof. Dr. PEDRO JACOB CHRISTOFFOLETI
}

\section{RESUMO}

Tradicionalmente o manejo das plantas daninhas é realizado levando-se em consideração a infestação média destas plantas nas áreas agrícolas; sendo então adotadas estratégias de manejo de forma homogênea em toda a área. Porém, as plantas daninhas não se distribuem uniformemente, sendo comum o comportamento contagioso, formando manchas ou "reboleiras". No entanto, a localização e mapeamento de diferentes infestações são tarefas difíceis de serem executadas em larga escala e requerem metodologias adequadas. Desta forma, métodos de determinação dessa variabilidade espacial necessitam de melhores esclarecimentos e estudos científicos. Com o objetivo de estudar o comportamento da variabilidade espacial das plantas daninhas e seu respectivo banco de sementes com a utilização de ferramentas da agricultura de precisão, foram realizados quatro experimentos para avaliar esta variabilidade espacial e temporal e analisar a potencialidade que a mesma pode proporcionar para o manejo racional das plantas daninhas, principalmente a possibilidade da aplicação localizada de herbicidas. O primeiro experimento consistiu do mapeamento do banco de sementes ao longo de dois anos consecutivos no intuito de comparar sua variabilidade espacial com a flora emergente. Concluiu-se que existe uma 
correlação entre o banco de sementes e a flora emergente e entre bancos de sementes de anos consecutivos, principalmente para as plantas daninhas Ageratum conyzoides L. e Commelina benghalensis L.. Analisando a dependência espacial, foi detectada uma dependência entre 7 e $15 \mathrm{~m}$ para o banco de sementes e a flora emergente. Os mapas gerados mostraram uma grande variabilidade espacial das plantas daninhas, sendo observadas algumas tendências de estabilidade ao longo do tempo. No segundo experimento foram feitos dois mapeamentos da infestação da planta Panicum maximum Jacq., um durante a colheita da cultura de milho e outro após a colheita, para fins de aferição do método de mapeamento realizado durante a colheita. Foi constatada uma subestimação de $6 \%$ da área infestada pelo método de mapeamento durante a colheita, quando este foi comparado com o caminhamento numa grade regular após a colheita. Os dois métodos foram coincidentes em $45 \%$ das áreas marcadas. $\mathrm{O}$ terceiro experimento consistiu de uma avaliação da eficácia da aplicação localizada de herbicidas pósemergentes na cultura da soja, baseada em mapas de infestação das plantas daninhas. Para isto foi feito uma amostragem numa grade de $6 \times 6 \mathrm{~m}$ e, baseado na infestação em cada célula, foi pulverizado duas doses de herbicidas pós-emergentes dependendo da infestação de cada local. Foi obtida uma economia de produto da ordem de 18 e 44\%, sendo a eficácia similar à aplicação convencional utilizando dose única e pulverização uniforme em área total. No quarto experimento foi realizada uma pulverização localizada de herbicida pré-emergente baseada no mapeamento prévio do banco de sementes das plantas daninhas; sendo verificado uma eficácia igual à convencional e uma economia de $22 \%$ de produto herbicida. Portanto, técnicas de mapeamento da variabilidade espacial das plantas daninhas são importantes ferramentas para que melhores decisões sejam tomadas dentro dos sistemas de produção agrícola, sendo de extrema urgência um maior conhecimento e embasamento técnico-científico de técnicas agronômicas que considerem esta variabilidade espacial. 


\title{
MAPPING WEED SPATIAL VARIABILITY USING PRECISION FARMING TOOLS
}

\author{
Author: LUCIANO SHOZO SHIRATSUCHI \\ Adviser: Prof. Dr. PEDRO JACOB CHRISTOFFOLETI
}

\section{SUMMARY}

Traditionally the weed management has been done considering the overall weed infestation in the whole field and then herbicides are sprayed according to a single weed control recommendation for the field. But weeds are not uniformly distributed and normally have clumped populations showing weed patches presenting high spatial variability. This nature of the weed populations can be mapped, and so it can help the decisions associated with weed management on agricultural systems. However, localization and mapping of the weed clusters are very difficult tasks in large areas, and require adequate methodology. Therefore, determination method of this weed infestation variability in space must be scientifically studied. With the objective of studying the weed spatial variability and temporal behavior of weed seedlings infestations and their respective seed banks, four experiments were conducted to evaluate the spatial temporal behavior of the weeds and the potential of weed mapping technology could bring to the rational weed management. The aim of the first experiment was to evaluate the spatial temporal behavior of the weed seedlings and their respective seed banks using the mapping technology. A grid sampling was used to understand the seedling and seed bank behavior in the space and time. Correlations using "Spearman rank" test were observed, mainly in Ageratum conyzoides L. and Commelina benghalensis L. The 
spatial dependence was noted between 7 and $15 \mathrm{~m}$ for the weed seedlings and seed banks. The weed maps showed that the weeds have a high spatial variability making patches with some temporal stability. In the second experiment two weed surveys were done with the objective of mapping Panicum maximum Jacq. during and after corn harvest. The grid sampling method after harvest corn was used to evaluate the harvest mapping method. It was underestimated about $6 \%$ of the weed infestation using the harvest mapping method when it was compared with the grid sampling method after corn harvest. In this experiment the harvest mapping method had just $45 \%$ of efficiency in recording weed infestation areas. The third experiment was done in order to analyzed the post emergence herbicide efficacy in soybeans based on weed maps constructed with grid sampling mapping. The weed seedling was counted in a 6 by $6 \mathrm{~m}$ grid and, based on weed infestation of each grid, it was sprayed two post emergence herbicide rates according to the weed infestation. It was saved 18 to $44 \%$ of herbicides compared to broadcast application with the same herbicide efficacy. In the fourth experiment a pre emergence herbicide application was carried out in soybeans crop based on weed seed bank map and, it was observed that the site-specific application had similar efficacy saving $22 \%$ of herbicides. So, the weed mapping technology is an important tool to bear on decisions associated with crop production, and it is a priority for the implementation of this technology multiple sources of scientific knowledge in weed biology and management regarding to the weed spatial variability. 


\section{INTRODUÇÃO}

Com o aumento da competitividade e decréscimo dos preços dos produtos agrícolas, no mercado mundial globalizado, a agricultura se depara com a necessidade de otimizar a utilização dos recursos de produção. Altas produtividades vêm sendo observadas em áreas agrícolas onde grandes investimentos em tecnologia e produtos têm sido aplicados. Porém, mais importante que altas produtividades é a utilização racional e econômica destes recursos e técnicas de produção agrícola.

Dentro deste cenário a utilização e desenvolvimento de novas ferramentas gerenciais, como a agricultura de precisão, se tornam necessárias. O Conselho Nacional de Pesquisa dos Estados Unidos definiu a agricultura de precisão como: "Manejo estratégico que utiliza a tecnologia da informação para reunir dados de múltiplas fontes levando a melhor tomada de decisão dentro do sistema de produção agrícola" (National Research Council, 1997). Esta nova concepção de agricultura considera que a variabilidade espacial dos diversos fatores que interferem na produção agrícola, tais como: fertilidade, tipo, umidade e compactação do solo, produtividade, temperatura, pragas, doenças, plantas daninhas, etc. devem ser consideradas. Portanto, informações da variabilidade espacial destes fatores nas áreas agrícolas devem ser analisadas com um nível maior de detalhamento para a racionalização e otimização das práticas de manejo nas áreas agrícolas.

Com a utilização de técnicas e ferramentas disponíveis da agricultura de precisão, é possível fazer o mapeamento de diversas variáveis. Dentre elas o mapeamento das plantas daninhas merece especial atenção. Economias da ordem de 30 a $72 \%$ do volume

de herbicidas aplicados em áreas agrícolas já foram obtidas na Europa em lavouras de 
soja quando aplicações localizadas dos herbicidas foram feitas com base no mapeamento das plantas daninhas em comparação com aplicações convencionais em área total (Christensen et al., 1999a). A preocupação da racionalização do uso de herbicidas em áreas agrícolas é muito relevante, pois, segundo o FNP Consultoria \& Comércio (2000) no Brasil os herbicidas podem contribuir em até $25 \%$ do custo total de produção na cultura da soja em plantio direto, $9 \%$ na cultura do milho e $6 \%$ na cultura do algodão.

Porém, para que o mapeamento da variabilidade espacial das plantas daninhas torne-se uma prática rotineira de tomada de decisão final, as recomendações de aplicação de herbicidas com tratamentos a taxas variáveis, ou seja, a aplicação localizada de herbicidas na agricultura necessita ainda de muitas pesquisas básicas.

Sendo assim, os objetivos desta pesquisa são de (i) Avaliar metodologias de mapeamento de plantas daninhas com relação à sua viabilidade técnica e prática de uso nos sistemas de produção agrícola com o auxílio de ferramentas da agricultura de precisão, (ii) Analisar a economicidade e eficácia do controle químico das plantas daninhas baseado no mapeamento da variabilidade espacial das plantas daninhas, (iii) Realizar uma metodologia de mapeamento da variabilidade espacial do banco de sementes de plantas daninhas, analisando sua estabilidade temporal e (iv) Correlacionar os mapas de distribuição de plantas daninhas com seu respectivo banco de sementes. 


\section{REVISÃO DE LITERATURA}

\subsection{Agricultura de precisão: Definição e breve histórico}

Definida como um elenco de tecnologias e procedimentos utilizados para que os sistemas de produção agrícolas sejam otimizados, tendo como elemento chave, o gerenciamento da variabilidade espacial da produção e os fatores a ela relacionados, sendo na verdade um sistema de gestão ou gerenciamento (Molin, 2000).

Esta filosofia de trabalho e gerenciamento localizado que se embasa no conceito de tratamento diferenciado das áreas agrícolas, não é nova, foi inicialmente praticada pelos pesquisadores Linsley e Bauer da Universidade de Illinois, Estados Unidos da América do Norte, ainda no ano de 1929. Os pesquisadores realizaram o tratamento localizado da correção do pH de uma área de 17 ha com base em dados de 23 amostras de solo ordenadamente coletadas (Molin, 1997). Porém esta aplicação foi realizada manualmente devido ao pequeno tamanho da área.

Com o advento da mecanização e a revolução verde, a agricultura de precisão foi esquecida, pois o tipo de tratamento localizado possível naquela época era inviável para extensas áreas agrícolas, que era o objetivo principal da agricultura no momento, sendo o tratamento localizado impraticável.

A partir de 1980 com os diversos avanços tecnológicos, como computadores, satélites, softwares de sistemas de informações geográficas, sensores e outros conjuntos de ferramentas e técnicas de produção tornaram-se disponíveis para a agricultura. Muitos deles tiveram adaptações para o meio rural, já que foram idealizados para outros fins. Porém todas estas recentes evoluções tecnológicas nos diversos campos 
possibilitaram que a automação de processos e sistemas pudessem se tornar realidade, possibilitando a prática da agricultura de precisão, que segundo Mantovani (2000) necessita de algumas tecnologias ou ferramentas básicas, tais como: GPS (Global Positioning System - Sistema de Posicionamento Global), sistemas de informações geográficas (SIG) e sensoriamento.

\subsection{Sistema de posicionamento global (GPS)}

Um dos requisitos para a aplicação da agricultura de precisão é a utilização de um sistema de posicionamento que permita a localização georeferenciada com precisão suficiente em todos os pontos e porções escolhidas dentro da área agrícola. Um sistema que atende a esse requisito foi desenvolvido pelo departamento de defesa dos Estados Unidos da América do Norte e recebeu o nome de sistema de posicionamento global GPS (Global Positioning System).

O sistema de posicionamento global consiste da triangulação de um conjunto de satélites, normalmente 24 satélites, que através do cálculo da distância entre eles baseada na diferença de tempo de transmissão dos sinais entre o receptor do usuário e os satélites determinam o posicionamento terrestre. No mínimo, são necessários três satélites para o posicionamento, porém para aumentar a precisão de tempo e posicionamento, normalmente os receptores utilizam quatro satélites (Molin, 1998).

O GPS foi utilizado inicialmente com finalidades militares nos Estados Unidos da América do Norte. Porém, o sinal sem degradação ou ruídos possuía um acesso somente para uso dos militares (Selective Availability - S/A), sendo disponibilizado somente o sinal acrescido de ruídos propositais para os civis. Porém atualmente este sinal sem degradação foi disponibilizado para os civis, aumentando significativamente a precisão dos equipamentos utilizados.

Devido à retirada do erro proposital imposto pelos Estados Unidos da América do Norte através do S/A no dia 2 de maio de 2000 (National Oceanic and Atmospheric Administration, 2001), equipamentos que antes possuíam pouca precisão com erros de posicionamento que podiam chegar até $100 \mathrm{~m}$, atualmente são mais precisos e possuem 
erros de aproximadamente $20 \mathrm{~m}$, da mesma forma que equipamentos com correção diferencial via satélite, que antes da retirada do erro geravam posicionamento com erros de até $6 \mathrm{~m}$ hoje possuem uma precisão com erros de 2 a 3 metros (Dana, 2001). Portanto, com a atual melhora da precisão no georeferenciamento e a facilidade na aquisição de sinais de satélite, torna-se acessível e possível a adoção de ferramentas da agricultura de precisão na agricultura.

\subsection{Sistemas de Informação Geográfica (SIG ou GIS)}

Os Sistemas de Informação Geográfica consistem na aplicação de softwares que analisam os dados espaciais obtidos no campo, sendo uma ferramenta de manipulação de dados espaciais, ou um modo de digitalização de mapas, possibilitando a organização, a análise estatística e a apresentação de diversos tipos de dados espaciais num sistema comum de coordenadas geográficas (National Research Council, 1997). Cada conjunto de dados é agrupado em mapas, como por exemplo, o mapa de fertilidade de solos, de tipos de solos, topografia, pragas, plantas daninhas, doenças, umidade, etc. Com estes sistemas podem ser feitas comparações entre vários mapas, possibilitando desta maneira o melhor entendimento do sistema de produção agrícola, sendo possível a criação de modelos agronômicos e sistemas de suporte à tomada de decisão (Marois, 2000).

O SIG é atualmente a principal ferramenta utilizada para o entendimento dos dados de distribuição espacial com grande número de informações, elaborando mapas de cada atributo, analisando e correlacionando-os.

\subsection{Geoestatística}

Quando uma determinada propriedade ou parâmetro varia de um local para outro com algum grau de organização ou continuidade, expresso através de dependência espacial, a estatística tradicional deve ser complementada pela Geoestatística (Vieira, 2000). 
Por estatística tradicional entende-se aquela que utiliza parâmetros como média e desvio padrão para representar um fenômeno, e baseia-se na hipótese principal de que as variações de um local para outro são aleatórias. Desse modo, estes dois ramos da estatística têm validade de aplicação em condições distintas (Vieira, 2000). Para determinar a necessidade do uso de ferramentas geoestatísticas utiliza-se o semivariograma, que é responsável por demonstrar a dependência espacial entre as amostras.

O semivariograma determina esta dependência espacial, basicamente por três parâmetros quando algum modelo é ajustado ao mesmo. O conhecimento dos principais parâmetros do semivariograma (Figura 1) é muito importante durante o estudo da dependência espacial das plantas daninhas. Os principais parâmetros de um semivariograma são (Trangmar et al., 1985): (i) alcance ou "range", que representa a distância limite até a qual se tem dependência espacial entre amostras, (ii) patamar ou "sill", é o valor da assíntota do modelo ajustado aos dados, também é utilizado para o cálculo do alcance, que, segundo Vieira et al. (1983) é aproximadamente igual à variância dos dados e (iii) intercepto ou "nugget", que representa a variância para $h=0$, o intercepto é considerado como um erro amostral ou uma medida não explicada pela escala de observação utilizada no estudo do fenômeno natural. Quando o intercepto aproxima-se de zero, a variância pode ser totalmente explicada pela dependência espacial dos dados (Zanin et al, 1998).

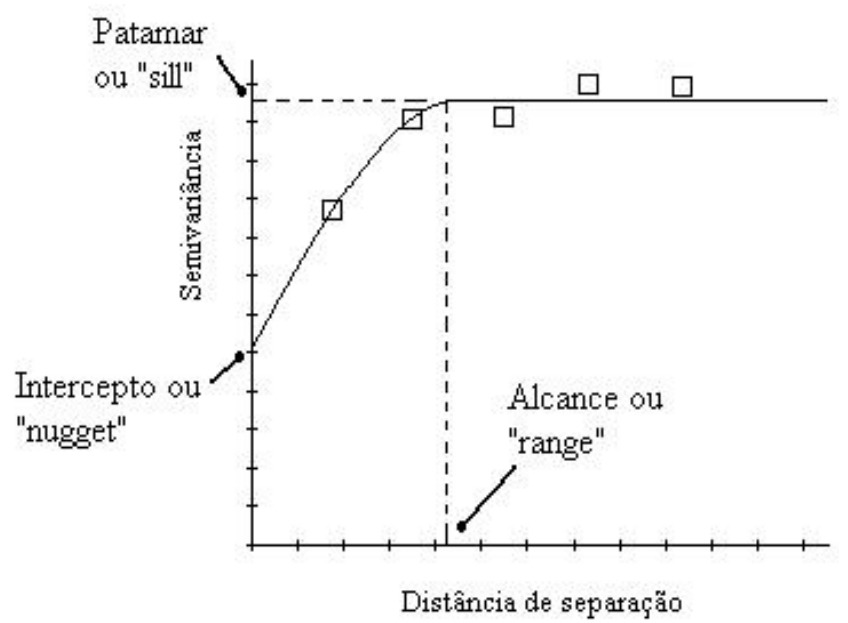

Figura 1 - Gráfico mostrando os principais parâmetros de um semivariograma. 
Havendo a dependência espacial após a análise dos semivariogramas, pode-se estimar valores da propriedade em estudo para os locais não amostrados no campo, sem tendência e com variância mínima, através do método denominado "krigagem" (palavra convencionalmente utilizada na geoestatística como tradução da língua inglesa do termo “Kriging”) (Isaaks \& Srivastava, 1989). A "krigagem" consiste de uma técnica de interpolação que faz ótima a estimação de variáveis regionalizadas, utilizando parâmetros dos semivariogramas e os valores das amostragens feitas (Trangmar et al., 1985).

$\mathrm{Na}$ ciência das plantas daninhas, resumidamente, as principais etapas a serem seguidas para a análise da variabilidade espacial são (i) análise exploratória dos dados, (ii) transformações e retirada de tendências quando estas existirem, (iii) análise da semivariância por meio dos semivariogramas e ajuste de modelos, (iv) interpolação por "krigagem" utilizando os parâmetros do modelo ajustado, (v) construção de mapas de infestação de plantas daninhas com a superfície de dados estimados (Heisel et al. 1996a).

O delineamento de espaçamentos e disposições ótimas de amostras no campo são outras aplicações imediatas possíveis de se efetuar utilizando a geoestatística (Vieira, 2000).

\subsection{Mapeamento das plantas daninhas}

Diversos estudos têm mostrado que muitas espécies de plantas daninhas estão agregadas ou freqüentemente ocorrem em "reboleiras" de diversas densidades. E segundo Nordmeyer et al. (1997), esta distribuição contagiosa deve-se principalmente a aspectos da biologia das plantas daninhas. Outros fatores também podem ser indicadores de maior agregação de plantas daninhas, tais como, umidade do solo, topografia, tipos de solos, produtividade da cultura e outros (Kvien et al., 1997). Devido ao fato da maioria das plantas daninhas infestarem as áreas agrícolas em "reboleiras", foi que surgiu a idéia do mapeamento de suas distribuições no campo, para fins de tratamentos a taxas variáveis, como estudos de variabilidade espacial das plantas daninhas e a aplicação localizada de herbicidas. 
No mapeamento de infestações das plantas daninhas, além da localização das áreas de ocorrência é muito importante conhecer aspectos da biologia destas plantas daninhas, tais como níveis de infestações, grau de contagiosidade, espécies presentes, capacidade de reprodução destas espécies influenciando o banco de sementes e comportamento em relação às condições edafoclimáticas. Heisel et al. (1996b) verificaram que as criações de mapas de tratamentos herbicidas dependem muito das propriedades do solo e de correlações de vários fatores relacionados com a biologia das plantas daninhas. Também relataram sobre a importância de correlações de mapas de infestações de anos anteriores para geração de novos mapas de controle químico das plantas daninhas.

Existem diversas metodologias de mapeamento das plantas daninhas. Lutman \& Perry (1999) dividiram as técnicas de mapeamento das plantas daninhas em dois grandes grupos: (i) Técnicas de detecção manual, a qual é feita por avaliadores que percorrem a área avaliando visualmente a presença das plantas daninhas; neste método normalmente é feita a divisão da área em grades ("grids") e a detecção visual pode ser auxiliada utilizando unidades móveis como quadriciclos ou colhedoras e (ii) Técnicas de detecção automatizadas, onde o mapeamento normalmente é feito por imagens aéreas retiradas à partir de unidades móveis de vôo de baixa altitude, satélites e outras formas de sensoriamento. Dentro destes dois grandes grupos a técnica mais utilizada, principalmente em pesquisa é o mapeamento pelo método de amostragens em grade ("grid sampling").

\subsubsection{Mapeamento pelo método de contorno das infestações}

Este método consiste no caminhamento pelo campo contornando-se as "reboleiras" de plantas daninhas, registrando infestações e espécies, normalmente com o auxílio de um computador portátil e uma mochila contendo um GPS (Stafford et al. 1996). Desta forma serão determinados os locais das "reboleiras" de plantas daninhas no campo, sua flora daninha e níveis de infestações destas espécies. Gerando mapas de prescrição que servirão de base para posterior aplicação de herbicida. 
Kvien et al. (1997) compararam dois métodos de controle baseados em mapeamento, por contorno e por sensores, numa área de 1,6 ha. A metodologia utilizando sensores de altura de plantas detectou 0,23 ha coberto por uma determinada planta daninha e a de contorno detectou 0,17 ha da mesma planta, portanto, infestações bastante próximas.

Colliver et al. (1996) comparando três métodos de mapeamento: (i) Durante a colheita, (ii) Método de contorno das "reboleiras" e (iii) Contagem de plântulas jovens (seedlings) dentro de uma grade de $5 \times 10 \mathrm{~m}$, verificaram que o método de mapeamento de plantas daninhas na colheita pode superestimar a área infestada, apesar de ser o mais eficiente, pois não é necessário gasto de tempo no mapeamento já que o levantamento dá-se na operação da colheita. Os autores citam que o grau de dificuldade de se contornar uma reboleira depende do nível de infestação, do grau de contagiosidade e do tipo de planta estudada. Também comentam sobre a importância de se conhecer aspectos biológicos e comportamentais da planta daninha, tais como, a estabilidade da localização das reboleiras ao longo dos anos, hábito de crescimento e tipo de dispersão das sementes, pois isto influencia diretamente o mapeamento e a previsão de infestações posteriores.

$\mathrm{Na}$ geração de polígonos georeferenciados pelo caminhamento ao redor das reboleiras é importante ressaltar que existem erros de posicionamento, que irão depender da precisão do equipamento usado, sendo necessários a criação de áreas de segurança para a confecção de mapas de aplicação herbicida. Lass \& Callihan (1993) obtiveram polígonos de plantas daninhas contornadas em seu perímetro com uma precisão de $10 \mathrm{~m}$ quando o receptor DGPS estava em movimento e de aproximadamente $2 \mathrm{~m}$ quando existiam breves paradas durante a aquisição de dados. Porém testes de precisão, após a abolição da disponibilidade seletiva (S/A) pelos Estados Unidos da América do Norte, ainda são poucos e devem ser padronizados. 


\subsubsection{Mapeamento pelo método de amostragens em grade ("grid")}

Este método consiste na divisão da área agrícola em quadrículas ou em pequenas células de amostragem gerando uma grade pré-determinada e georeferenciada onde são feitas amostragens sistemáticas sobre a comunidade de plantas daninhas, gerando desta maneira uma amostra que represente aquela sub área. Estas informações coletadas em cada subárea são convertidas em um mapa de infestação de plantas daninhas por “krigagem” ou por outro método relacionado (Lutman \& Perry, 1999).

Segundo diversos autores (Stafford \& Miller 1996, Christensen et al., 1999a; Lutman \& Perry, 1999) esta metodologia é demorada e trabalhosa de ser realizada em grandes áreas, principalmente se a grade for muito pequena, gerando um número de amostras inviável de se coletar na prática. Porém quanto menor a grade maior a resolução e confiabilidade. Segundo Lutman \& Perry (1999) 6 x 6 m foi considerado o tamanho máximo de uma grade, pois grades maiores podem gerar mapas com baixa resolução inviabilizando a técnica.

No mapeamento de plantas daninhas pelo método de amostragens em grade a definição da área mínima de amostragem dentro da grade amostral é definida como sendo a área onde a composição de espécies da comunidade de plantas daninhas em estudo é satisfatoriamente representada (Barbour et al., 1987). As áreas mínimas amostrais para a realização do mapeamento das plantas daninhas já foram realizadas

utilizando quadrados amostrais de $0,06 \mathrm{~m}^{2}$ a $0,38 \mathrm{~m}^{2}$ (Dessaint et al. 1991; Cardina et al. 1996; Gehards et al. 1996).

Nordmeyer et al. (1997) fizeram um mapeamento de plantas daninhas pelo método de amostragem em grade numa área de 13 ha utilizando uma grade de 30 x $30 \mathrm{~m}$ e um quadrado amostral de $0,1 \mathrm{~m}^{2}$. Em uma das duas áreas estudadas pelo método de amostragens os mapas gerados mostraram necessidade de pulverização em apenas $60 \%$ da área. Na outra área experimental, 70\% necessitou de pulverização para dicotiledôneas e não se justificava pulverização localizada para monocotiledôneas, devido à infestação generalizada e uniforme em toda área. Já Heisel et al. (1996b) realizando um experimento numa área de 8 hectares utilizando uma grade de 20 x $20 \mathrm{~m}$ e amostrador 
circular de $0,25 \mathrm{~m}^{2}$, verificaram economias de herbicidas da ordem de 66 a $75 \%$ comparado com o sistema convencional.

Gehards et al. (1996) estudaram a distribuição de "reboleiras" de plantas daninhas para a aplicação de herbicidas de pré e pós-emergência num período de quatro anos. Para a recomendação de herbicidas de pós-emergência utilizaram uma grade de 7 x $7 \mathrm{~m}$ e um quadrado amostral de $0,38 \mathrm{~m}^{2}$, chegaram a conclusão que as folhas largas possuem um comportamento mais estável que as folhas estreitas.

São inúmeros os tamanhos de grades amostrais já utilizadas em diversos experimentos para se determinar a distribuição espacial das plantas daninhas. Cardina et al. (1997) citam trabalhos na literatura com grades variando de 0,5 x 0,5m até $36 \times 40 \mathrm{~m}$. Alguns autores (Paice et al., 1998, Lutman \& Perry, 1999) citam que grades maiores que 6 x 6 m podem ser não representativas para o estudo espacial das plantas daninhas em geral.

Christensen et al (1999a) no intuito de diminuir o tempo de amostragem em grade tentaram quantificar a infestação das plantas daninhas através do índice de cobertura do terreno. Para isso utilizaram uma câmera com lente de $60 \mathrm{~mm}$, a seguir digitalizaram a imagem num scanner gerando imagens que, após tratamento e digitalização, determinaram a porcentagem de cobertura do terreno. Tendo as diferentes taxas de cobertura do terreno e as diferentes densidades das plantas daninhas foi possível a correlação entre estas variáveis. Foi observada uma alta correlação, porém a mesma foi quantificada somente visualmente através dos mapas interpolados.

Segundo Lutman \& Perry (1999), a técnica de amostragens em grade é perfeitamente aceitável para fins de pesquisa, porém ainda existem limitações sobre sua utilização na prática para a confecção rápida de mapas de aplicações herbicidas, principalmente em áreas extensas.

\subsubsection{Mapeamento das plantas daninhas na colheita da cultura}

Consiste na marcação georeferenciada da infestação das plantas daninhas durante a operação de colheita, ou seja, durante o caminhamento da colhedora equipada com 
DGPS, o operador faz marcações quando o mesmo entra em alguma "reboleira" de planta daninha. Através da largura da plataforma de colheita e da posição em que o operador começou e terminou a marcação é possível calcular uma faixa onde foi considerada a presença de determinada planta daninha (Colliver et al., 1996). Após a colheita e o processamento dos dados em um software específico as faixas de infestações geram um mapa de infestação de plantas daninhas.

Dentre as diversas metodologias testadas para a realização do mapeamento das plantas daninhas, o mapeamento durante a colheita da cultura é atualmente a mais utilizada em áreas de produção agrícolas nos Estados Unidos da América do Norte pela facilidade metodológica de mapeamento, pois ela aproveita a operação de colheita para realização do mapeamento. Sendo assim, é possível obter mapas pós-colheitas que poderão servir de base para a próxima cultura ou até racionalizar a aplicação de herbicidas de manejo para a cultura em sucessão, já que as plantas daninhas apresentam certa estabilidade espacial ao longo tempo (Clay \& Johnson, 2001).

Diversos trabalhos científicos têm mostrado que a dispersão de plantas daninhas pelas operações de cultivo e colheita é um dos principais fatores que influenciam a localização de futuras "reboleiras", e estas são matematicamente previsíveis (Colliver et al., 1996).

Porém o mapeamento na colheita apresenta algumas limitações tais como: necessidade de um operador que possua experiência na identificação das plantas daninhas, subestimação da infestação das plantas daninhas devido à sobreposição das plantas daninhas pela cultura, época de avaliação não coincidente com o período de competição e subjetividade de avaliação quando se alternam operadores.

\subsubsection{Mapeamento do banco de sementes das plantas daninhas}

O banco de sementes no solo tem sido utilizado na literatura para descrever o montante de sementes viáveis e outras estruturas de propagação presentes no solo ou nos restos vegetais (Carmona, 1992). 
O conhecimento das características do banco de sementes de plantas daninhas é de grande importância na tomada de decisão da adoção de técnicas de manejo nos sistemas agrícolas. Segundo diversos autores (Wilson et al., 1985; Ball \& Miller, 1989, Forcella, 1992, Christoffoleti \& Caetano, 1998) a caracterização do banco de sementes fornece informações históricas da influência das práticas de manejo já utilizadas na área, bem como possibilita previsão de potencial de futuras infestações, pois sabendo seu tamanho e espécies presentes, o banco de sementes pode ser utilizado para previsões de manejo na área.

Da mesma forma que as populações emergentes de plantas daninhas possuem um certo grau de contagiosidade é esperado que seus respectivos bancos de sementes também possuam este comportamento, sendo este pouco modificado de um ano para outro, ou de uma cultura para outra como a flora daninha emergente, pois esta sofre reflexos diretos em curto prazo de tempo, às vezes de um ano para outro ou dentre sistemas de produção diferenciados. Indicativos de que o banco de sementes é o principal fator da estabilidade das "reboleiras" das plantas daninhas é citado por Dieleman \& Mortensen (1999) estudando a estabilidade temporal de Abutilon theophrasti.

Esta estabilidade temporal do banco de sementes foi observada por Cardina et al. (1996), utilizando uma grade de avaliação de 3 x $7 \mathrm{~m}$ e de 1 x $1 \mathrm{~m}$ no levantamento do banco de sementes na cultura da soja em plantio direto. Cardina et al. (1997) citaram autores $^{1}$ que utilizaram uma grade de $0,5 \times 0,5 \mathrm{~m}$ em culturas de cereais e observaram estabilidade de distribuição espacial das sementes no solo ao longo do tempo. Sendo assim, a quantificação do banco de sementes com localização geográfica das concentrações de sementes no solo com a utilização de mapeamento pode ser utilizada para planejar o manejo e prever o comportamento do banco de sementes em anos posteriores.

Um modelo espaço temporal para a quantificação da dispersão levando em consideração a densidade da planta daninha Alopecurus myosuroides durante 8 anos foi

${ }^{1}$ Dessaint \& Caussanel (1994). 
conduzido por Christensen et al. (1999b). Neste trabalho de pesquisa os autores utilizaram a quantificação da variabilidade espacial do banco de sementes inicial da planta daninha e simularam através de modelos matemáticos a eficiência e economicidade dos seguintes métodos de controle químico: (i) controle localizado baseado no nível de dano econômico, (ii) controle localizado onde as doses do herbicida foram determinadas pela densidade de plantas e diminuição de produção da cultura em função do grau de competição causada pelas plantas daninhas e (iii) aplicação uniforme de uma única dose de herbicida independente da densidade de plantas. Concluíram que o controle localizado baseado no modelo de densidade foi o que mais diminuiu a infestação da planta daninha, demonstrando uma tendência de redução de doses e maior economicidade, seguido pela dose uniforme em toda área que manteve a infestação aos níveis originais sem modificar a característica espacial. Já o controle localizado baseado no nível de dano econômico aumentou a dose de herbicida requerida durante os 8 anos e fez com que se diminuíssem as áreas livres da planta daninha devido a não pulverização em áreas com densidade abaixo da dose econômica.

Cardina et al. (1996) estudando a correlação espacial entre a flora emergente e o banco de sementes determinaram uma baixa correlação em gramíneas anuais, citando que existem dificuldades na determinação do banco de sementes, devido a diversos fatores como a dormência, a deterioração, época de amostragem e avaliação, espécie de planta e micro ambiente onde foi coletada a amostra. Voll (2000) também enfatiza sobre estas particularidades da biologia que governam a dinâmica do banco de sementes.

Além da variabilidade espacial, o banco de sementes também possui uma variabilidade vertical, pois dependendo do sistema de produção utilizado a distribuição vertical das sementes no perfil do solo é altamente afetada. Yenish et al. (1992) estudando esta distribuição vertical em diferentes sistemas e tipos de manejo de plantas daninhas relataram que em sistema de plantio direto de 90 a $96 \%$ do total de sementes encontraram se nos primeiros $6 \mathrm{~cm}$ de solo, principalmente devido ao não revolvimento do solo. Além disso, Carmona (1992) cita que sementes mais próximas a superfície estão mais sujeitas à predação, deterioração e a germinação. Portanto o conhecimento desta 
variabilidade vertical é muito importante previamente à escolha da profundidade de amostragem a ser realizada na determinação do banco de sementes (Barberi et al. 1998).

\subsection{Sistemas de aplicação localizada de herbicidas}

Devido à grande variabilidade espacial e ao comportamento contagioso das plantas daninhas, alguns estudos já foram conduzidos com aplicações localizadas de herbicidas (Shearer \& Jones, 1991; Hanks, 1996; Tian et al., 1999) no intuito de se melhorar a eficiência das aplicações herbicidas.

A aplicação localizada de herbicidas segundo Stafford \& Miller (1996) pode ser realizada de duas maneiras: (i) Baseada em mapas de infestações de plantas daninhas, ou seja, mapas de tratamentos e baseado nestes mapas gerados planejar uma posterior pulverização herbicida da área e (ii) Através de um sistema de detecção em tempo real (Real time), que consiste na pulverização herbicida logo após a detecção das plantas daninhas numa mesma operação.

\subsubsection{Aplicação localizada de herbicidas baseada em mapas}

Este tipo de aplicação localizada necessita de um mapeamento prévio das plantas daninhas na área de produção, gerando mapas da distribuição das plantas daninhas, possibilitando a confecção de mapas de tratamentos herbicidas que serão usados para o controle e acionamento dos pulverizadores dotados de GPS e softwares específicos que farão a leitura de onde aplicar, quanto aplicar e que produto ou mistura de produtos utilizar naquele local (Stafford \& Miller, 1996; Gehards et al. 1999).

A seguir estão listadas as etapas necessárias para a aplicação localizada de herbicidas baseada em mapas, desde o mapeamento prévio das plantas daninhas até a realização da pulverização localizada, baseada nestes mapas: (i) mapeamento prévio das plantas daninhas, (ii) confecção e análise destes mapas gerados, (iii) planejamento e escolha das áreas de manejo, (iv) confecção dos mapas de tratamentos, considerando 
espécies de plantas, produto herbicida a ser aplicado, dose, etc e (v) efetivação da pulverização localizada.

Pode se citar como vantagens da pulverização localizada de herbicidas baseada em mapas a (i) aplicação de herbicidas diferentes em uma mesma área em função do tipo de planta daninha, (ii) variação da dose do herbicida de acordo com a infestação de planta daninha e (iii) possibilidade de aplicação de vários tipos de misturas de herbicidas. E como principais limitações: (i) alto custo de mapeamento, (ii) grande utilização de mão de obra especializada para o mapeamento e (iii) aplicação do herbicida pós-emergente em estádio avançado de desenvolvimento da planta daninha em função do tempo entre o mapeamento e aplicação do herbicida.

\subsubsection{Aplicação localizada em tempo real ("Real time")}

Este tipo de aplicação localizada de herbicida não necessita de um mapeamento prévio da área infestada com plantas daninhas, pois a pulverização é baseada em sensores acoplados ao pulverizador que detectam a planta daninha acionando a pulverização (Antuniassi \& Gadanha Junior, 2000). Portanto, o GPS será importante somente para orientar o operador da pulverização para andar em linhas paralelas e para registrar as regiões onde foram pulverizadas, pois estas servirão de base para uma melhor confecção de mapas de tratamento herbicida na cultura posterior. Normalmente estes sensores estão acoplados na barra de pulverização (Figura 02).

A utilização de pulverizadores sofisticados com grande capacidade operacional torna-se comum neste tipo de aplicação localizada, pois grandes capacidades operacionais e qualidade na aplicação são buscadas com a utilização de dispositivos reguladores de pressão e fluxo e tanques herbicidas com vários herbicidas individualizados separados do tanque de água, possibilitando a aplicação de vários produtos combinados ou individualizados através de sistemas de injeção direta de defensivos como os citados por Antuniassi (2000), controlando a dose do produto e espectro de gotas. 


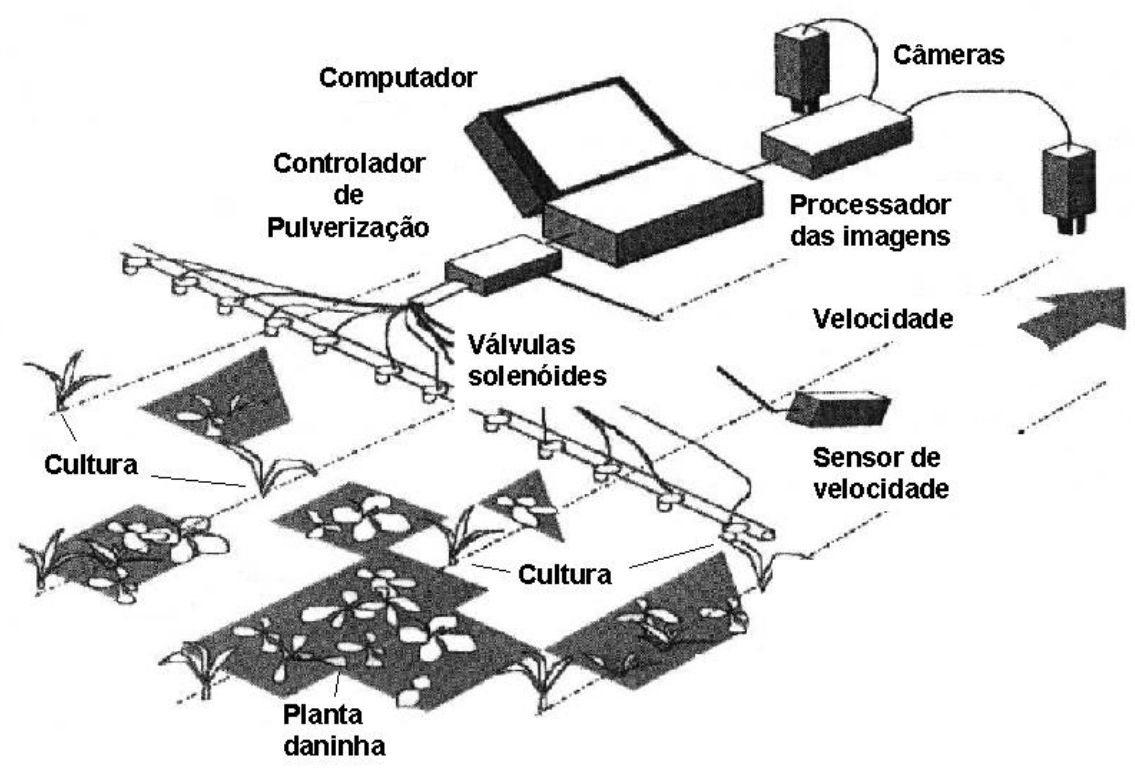

Figura 2 - Esquema de uma aplicação localizada de herbicida baseada na detecção em tempo real, adaptado de Tian et al. (1999).

Como vantagens da pulverização localizada de herbicidas em tempo real é relevante destacar: (i) maior rapidez na aplicação do herbicida, (ii) não necessita de mapeamento prévio e (iii) possui facilidade de mapeamento para planejamento de futuras aplicações. Porém algumas limitações são importantes, tais como, (i) a sensibilidade dos sensores é às vezes insuficiente, (ii) alto custo de equipamentos e (iii) há uma necessidade de regulagem, adaptação e calibração constante. 


\section{MAPEAMENTO DA VARIABILIDADE ESPACIAL E TEMPORAL DO BANCO DE SEMENTES DAS PLANTAS DANINHAS}

\section{Resumo}

Devido à grande variabilidade espacial das plantas daninhas formando manchas ou "reboleiras" de infestações nas áreas agrícolas é possível através do mapeamento deste comportamento a aplicação de herbicidas somente onde necessário, aumentando a economicidade e eficiência dos sistemas de produção agrícola. Porém muitos conhecimentos básicos da dinâmica das populações das plantas daninhas em relação à sua distribuição espacial necessitam de conhecimentos científicos, principalmente quando se refere ao banco de sementes das plantas daninhas. Neste sentido, este experimento foi realizado para o estudo do comportamento espacial do banco de sementes e sua flora emergente ao longo do tempo. Para o mapeamento foi utilizado um conjunto "DGPS" acoplado a uma mochila e a um computador portátil, sendo georeferenciado 194 pontos no primeiro ano, utilizando uma grade amostral de 20x20 m, e 480 pontos no segundo ano, com 194 pontos na mesma grade de 20x20 m e 286 pontos em duas sub áreas numa grade de $6 \times 6 \mathrm{~m}$. O banco de sementes foi coletado a $5 \mathrm{~cm}$ de profundidade e sua determinação feita pela emergência em casa de vegetação. A flora emergente foi determinada utilizando um quadrado amostral de $0,25 \mathrm{~m}^{2}$ sendo contadas todas as plantas emergidas por espécie. Para a correlação entre o banco de sementes e a flora emergente foi utilizado o teste de "Spearman rank". Observou se que houve uma correlação entre a flora emergida e o banco de sementes coletados em duas épocas, principalmente para as plantas Ageratum conyzoides e Commelina benghalensis. A flora e o banco de sementes tiveram uma dependência espacial entre 7 e $15 \mathrm{~m}$. 
Analisando os mapas gerados, ficou evidenciada a grande variabilidade espacial do banco de sementes e da flora emergente. Portanto, medidas de manejo das plantas daninhas devem considerar esta variabilidade no espaço e tempo.

\section{MAPPING THE SPATIAL AND TEMPORAL VARIABILITY OF WEED SEED BANKS}

\section{Summary}

The weed community presents high spatial variability and normally has a clumped shape and shows weed patches, so it is possible to map this behavior and then herbicides can be applied only where they are needed. Using this mapping technology herbicides consumption can be saved and a rational weed management implemented. But a few experiments regarding the weed seedling emergence and their respective seed banks, considering spatial and temporal variability have been done. This experiment was conducted with the objective to survey the method for mapping the spatial temporal distribution of the weed seedlings and their respective seed banks. It was used a backpack "DGPS" and a "palm top" computer to geo reference the samples. The density of the weed seedlings was assessed using a $0,25 \mathrm{~m}^{2}$ quadrat and the density was counted by species. For the seed bank quantification the soil cores were collected at 0,05 $\mathrm{m}$ depth and put into the greenhouse to seed bank germinating and then all the species were counted. In the first year it was used a 20 by $20 \mathrm{~m}$ grid and 194 samples were determined for the seed banks and 194 samples for the seedlings. At second year the same field was evaluated and more 286 samples were collected in a smaller ( 6 by $6 \mathrm{~m}$ ) grid. The weed seed banks and weed seedlings were analyzed using "Spearman rank" correlation, resulting in good correlations mainly for Ageratum conyzoides and Commelina benghalensis. The spatial dependence was about 7 to $15 \mathrm{~m}$ for weed seedlings and seed banks. The maps generated showed that the weed seed banks have a high spatial variability like their respective weed seedlings. It was concluded that the 
weed community have a high spatial variability and that the weed management methods used to control the weeds have to consider this behavior in space and time.

\subsection{Introdução}

A desuniformidade das infestações das plantas daninhas nas áreas agrícolas formam agregações que na maioria das situações ocorrem com alto grau de contagiosidade. No entanto, poucos estudos foram realizados até o momento para pesquisar a variabilidade espacial das plantas daninhas. Estes estudos revestem-se de grande importância no contexto da agricultura atual onde novas técnicas e ferramentas gerenciais que consideram a variabilidade espacial de fenômenos naturais, como a agricultura de precisão, estão em pleno desenvolvimento e aplicação.

Um aprimoramento de técnicas estatísticas de análise, como a geoestatística e estudos de métodos de mapeamento são essenciais para que melhores decisões de manejo de plantas daninhas sejam adotadas ao utilizar qualquer ferramenta que considere esta variabilidade espacial.

A aplicação localizada de herbicidas já é possível com os equipamentos e máquinas disponíveis no mercado (Lutman \& Perry, 1999; Antuniassi, 2000). Porém, a maneira de como gerar mapas para alimentarem estas máquinas ainda é uma incógnita, principalmente devido a grande dinâmica inerente das plantas daninhas.

Muitos trabalhos têm estudado o mapeamento da flora emergente por diversas técnicas (Feyarts et al. 1999; Pollet et al, 1999; Eberlein et al., 1999) existindo poucos trabalhos com o mapeamento do banco de sementes. Estudos feitos anteriormente já consideraram a importância do conhecimento da infestação do banco de sementes para predições de infestações futuras, porém nenhum considerou a variabilidade espacial dos bancos de sementes das plantas daninhas. Segundo Cardina et al. (1996) o conhecimento desta variabilidade espacial do banco de sementes e sua relação com a flora emergente considerando o espaço é muito importante na decisão da adoção de algum tratamento de controle químico localizado das plantas daninhas. 
Considerando a necessidade de melhor entendimento da dinâmica populacional do banco de sementes e sua flora daninha no espaço e no tempo foi conduzido este experimento com o intuito de mapear a flora daninha e seu respectivo banco de sementes, utilizando ferramentas da agricultura de precisão, procurando verificar o grau de correlação entre eles.

\subsection{Material e Métodos}

\subsubsection{Local e condições gerais do experimento.}

A área experimental de realização do experimento de campo pertence à Faculdade de Zootecnia e Engenharia de Alimentos da Universidade de São Paulo (USP/FZEA), localizada no município de Pirassununga/SP (Longitude: 47 $27^{\prime} 58^{\prime \prime} \mathrm{O}$; Latitude: $21^{\circ} 57^{\prime} 51^{\prime \prime} \mathrm{S}$ ). O experimento foi realizado sob um quadrante de 8,5 ha de uma área irrigada sob pivô central de 70 ha em solo classificado como terra roxa estruturada eutrófica.

Antes de ser semeada com milho em 1998, a área foi cultivada com pastagem de capim colonião (Panicum maximum Jacq.), desde então foram realizadas as seguintes sucessões de cultura: milho (1999-2000) - milho (2000) - milho (2000-2001) e soja (2001), todas cultivadas sob o sistema de plantio direto desde 1998. O histórico de herbicidas utilizado na área desde o início do primeiro plantio foi: glyphosate e atrazine (milho 1999); glyphosate e atrazine (milho 2000); glyphosate e acetochlor (milho 2000/2001); glyphosate, fluazifop butyl e fomesafen (soja 2001).

\subsubsection{Método de amostragem do banco de sementes}

Durante o mês de junho de 2000 e janeiro de 2001 foram feitas as amostragens de solo para a determinação do banco de sementes. Numa grade de 20 × 20 m pré-definida por um "software" de Sistema de Informação Geográfica (SIG) personalizado para 
agricultura de precisão ("SSToolBox/SST"2) foram definidos pontos amostrais no centro de cada grade, totalizando 194 pontos amostrais no primeiro ano e 480 pontos no segundo.

No primeiro ano (2000) foram realizadas amostragens sistemáticas do banco de sementes numa área de 8,5 ha utilizando uma grade amostral de 20 x $20 \mathrm{~m}$. No segundo ano (2001) a mesma área foi amostrada novamente, totalizando uma área de 8,5 ha na mesma grade amostral de $20 \times 20 \mathrm{~m}$, no intuito de se avaliar a variabilidade temporal das infestações das plantas daninhas. No segundo ano além dessa área de 8,5 ha, foram amostradas dentro da mesma duas sub áreas de 0,5 ha cada utilizando uma grade amostral mais detalhada de 6 × $6 \mathrm{~m}$. O intuito da amostragem mais detalhada foi a busca pela otimização do estudo da variabilidade espacial, que segundo vários autores (Vieira et at. 1981, Isaaks \& Srivastava, 1989, Cressie, 1991) é mais fácil de se detectar pelo melhor conhecimento da variabilidade espacial em grades menores.

Todos os pontos foram georeferenciados com o DGPS e estaqueados para que as coletas fossem feitas. A coleta de solo para determinação do banco de sementes foi feita ao lado da estaca. A grade mais detalhada de $6 \times 6 \mathrm{~m}$ foi feita com a utilização de trena, sendo suas extremidades georeferenciadas com o DGPS estacionado por um período de 15 minutos em cada um dos quatro pontos, devido à imprecisão observada ao tentar estaquear a área nesta grade.

Atrelados aos pontos georeferenciados foram atribuídos os resultados de densidade do banco de sementes das plantas daninhas em sementes. $\mathrm{m}^{-2}$.

\subsubsection{Procedimentos de determinação do banco de sementes}

Para a determinação do banco de sementes das plantas daninhas através das amostras de solo coletadas foi utilizado o método de avaliação pela emergência de

${ }^{2}$ SST DEVELOPMENT GROUP. SST Development Group, Inc. Programa SSToolbox v. 3.1.3: Software de Sistemas de Informações Geográficas (software). Oklahoma: Site Specific Technology Development Group, 1999 
plântulas em vasos colocados em casa de vegetação descritos por Wilson et al. (1985), Ball \& Miller (1989), Forcella (1992) e Cardina et al. (1996).

Foram coletadas duas sub amostras de solo em cada local numa profundidade de 0-5 cm com um trado de 7,5 $\mathrm{cm}$ de diâmetro, que foram homogeneizadas e reduzidas a uma amostra de $350 \mathrm{~g}$. As amostras foram colocadas em vasos plásticos quadrados com área de $121 \mathrm{~cm}^{2}$ e $6 \mathrm{~cm}$ de altura, sendo colocado areia lavada até a metade da profundidade total, sendo o restante preenchido com as amostras de solo, ficando com uma profundidade máxima de $3 \mathrm{~cm}$ para a germinação das sementes não dormentes e viáveis. Estes vasos foram mantidos sob condições controladas dentro de casa de vegetação, sendo realizadas 14 avaliações (uma contagem por semana) de todas as plântulas emergidas num período de 90 dias.

A determinação do banco de sementes pela emergência das sementes presentes nas amostras coletadas em junho de 2000 (BS00) foi realizada de 25 de setembro de 2000 a 8 de janeiro de 2001 e nas amostras coletadas em janeiro de 2001 (BS01), foi realizada de 23 de fevereiro a 25 de maio de 2001.

Para maximização e aumento da velocidade de emergência das plantas daninhas do banco de sementes, Carmona (1992) cita várias categorias de substâncias químicas que podem induzir a superação ou quebra de dormências fisiológicas das sementes, comuns em várias espécies de plantas daninhas. Dentre as categorias, os compostos nitrogenados tem apresentado resultados positivos para diversas espécies, e assim é utilizado na determinação do banco de sementes através da porcentagem de emergência das sementes no solo. Segundo Espeby (1989) o nitrato é o único íon inorgânico presente na solução do solo que afeta a germinação de uma vasta gama de espécies. No experimento foi utilizado o nitrato de amônio na dose de $100 \mathrm{~kg} \mathrm{~N}^{\mathrm{h}} \mathrm{ha}^{-1}$, sendo que as aplicações foram feitas após cada fluxo de germinação.

\subsubsection{Método de amostragem da flora emergente}

Foi utilizado o método de amostragens sistemáticas utilizando as mesmas grades amostrais de 20 × 20 m e 6 × 6 m utilizadas para a quantificação do banco de sementes. 
Em cada ponto foi lançado duas vezes (2 sub amostras) um quadrado amostral de $0,25 \mathrm{~m}^{2}$. Dentro do quadrado foram contadas todas as plantas daninhas emergidas, sendo quantificada por espécie, ou seja, a flora emergente (F01). No momento da avaliação a cultura de soja que foi plantada no início de março de 2001, encontrava-se no estádio fenológico V3-V4 (Fehr \& Caviness, 1977). Os resultados das contagens de plantas daninhas foram convertidos para plantas. $\mathrm{m}^{-2}$.

A população de plantas daninhas foi amostrada nos mesmos pontos de amostragens do banco de sementes para estabelecer as correlações entre ambos. Como a área foi estaqueada para a determinação do banco de sementes, o quadrado foi lançado duas vezes ao lado de onde foi retirada a amostra de solo para determinação do banco de sementes.

\subsubsection{Equipamentos e softwares utilizados}

A navegação em campo foi feita com a utilização de um GPS com correção diferencial em tempo real via satélite e um computador portátil munido de um programa de navegação denominado "Field Rover/SST" fornecidos pelo Departamento de Engenharia Rural da USP/ESALQ. Também foi utilizado um GPS sem correção diferencial para outras verificações quando sua precisão era suficiente. Por meio do programa "SSToolbox/SST" realizou-se a confecção dos mapas, interpolações pelo método do inverso da distância e por "krigagem" e armazenamento das demais informações necessárias. Para a análises estatísticas exploratória e de correlação foi utilizado o software Statistica ${ }^{3}$, e no ajuste dos parâmetros dos modelos utilizados para a "krigagem" foi utilizado o software GS $+{ }^{4}$.

${ }^{3}$ STATSOFT Inc. Programa Statistica for windows, versão 4.3: Software de análise estatística (software) Statsoft, 1993.

${ }^{4}$ GAMMA DESIGN SOFTWARE. Gamma Design Software Inc. Programa GS+: Geostatistics for environmental Sciences: Software de análise geoestatística (software). Michigan: Gamma Design Software, 1989 - 1999. 


\subsubsection{Análises estatísticas}

Foram realizadas análises descritivas dos dados e calculados índices que indicam a agregação das plantas daninhas. Para as correlações entre banco de sementes e a flora emergente foi utilizado a correlação de "Spearman rank" (Steel \& Torrie, 1980) e por último foi feita a análise geoestatística dos dados.

Previamente ao estudo da dependência espacial do banco de sementes e da flora emergente das plantas daninhas os resultados de densidade foram submetidos à análise descritiva e exploratória. Segundo Isaaks \& Srivastava (1989), Cressie (1991) e Ribeiro Junior (1995) a análise espacial dos dados depende da adequação da análise estatística exploratória que antecede a análise espacial, pois esta pode ocultar tendências dos dados. Ribeiro Junior (1995) também ressalta a importância da análise exploratória preliminar que tem papel fundamental na determinação das hipóteses assumidas e orienta a escolha da análise a ser desenvolvida.

Para um indicativo de agregação espacial foi utilizado o índice de dispersão ou contagiosidade (ID), que pode ser expresso como:

$$
\mathrm{ID}=\sigma^{2} / \mu
$$

onde $\mu$ se refere a média aritmética das amostras e $\sigma^{2}$ a variância. Segundo Dessaint et al. (1991) a taxa da variância sobre a média mede o desvio da unidade, ou seja, valores maiores que a unidade indicam um padrão de agregação espacial.

$\mathrm{Na}$ análise espacial foram utilizadas técnicas geoestatísticas para a medição da semivariância dos dados, através do semivariograma, que faz a comparação entre pares de pontos separados por uma distância h (Cressie, 1991):

$$
\gamma(h)=1 / 2 \operatorname{Var}[Z(x)-Z(x+h)], \text { para todo } h \text {. }
$$


O semivariograma determina o grau de similaridade entre valores (densidade de plantas daninhas) em função da distância de separação e direção e pode ser estimado através da seguinte expressão:

$$
\gamma^{*}=1 /\left(2 \mathrm{~N}_{(\mathrm{h})}\right) \Sigma[\mathrm{Z}(\mathrm{i})-\mathrm{Z}(\mathrm{i}+\mathrm{h})]^{2}
$$

onde $\gamma^{*}$ é o semivariograma empírico para uma dada distância (h), Z(i) representa a densidade da planta daninha na posição i, $\mathrm{N}_{(\mathrm{h})}$ é o numero de pares de pontos separados por h.

\subsubsection{Análise espacial da população das plantas daninhas}

Foram escolhidas para a análise espacial somente as plantas daninhas mais abundantes, que provavelmente interferiram de forma significativa na produção final de grãos de soja caso não fossem controladas: Alternanthera tenella, Panicum maximum, Ageratum conyzoides e Commelina benghalensis, sendo as demais plantas agrupadas em duas classes: (i) monocotiledôneas e (ii) dicotiledôneas.

A densidade média das plantas daninhas (banco e flora) em cada amostra georeferenciada, representadas por $\mathrm{y}$, foram transformadas em: $\mathrm{y}_{\mathrm{i}}=\log (\mathrm{y}+1)$, como realizado por Cardina et al. (1995), pois as plantas daninhas apresentam inúmeras amostras onde não são encontradas nenhuma planta ou semente, ou seja, que recebe o valor zero. E todas apresentaram uma distribuição log normal.

Após a transformação dos dados, foi realizada a análise espacial, ou seja, o ajuste dos semivariogramas para a determinação dos parâmetros dos modelos (intercepto, patamar e alcance) com a utilização do software GS+.

O melhor modelo testado pela validação cruzada com dados da "krigagem" em blocos 2 x 2 considerando para a estimação os 16 vizinhos mais próximos, foi escolhido e posteriormente foi utilizado para a realização da interpolação por "krigagem" com os dados originais de contagem do banco de sementes e da flora emergente para a criação dos mapas de infestações para a determinação espacial e temporal das infestações. 
Nenhum dado discrepante foi descartado durante a "krigagem" para a geração dos mapas.

Após a interpolação foram escolhidas três classes de densidade de plantas emergidas e banco de sementes utilizando o programa "SSToolbox/SST" dividindo a densidade de plantas daninhas e sementes em classes semelhantes. O cálculo da área de cada classe de densidade (sementes. $\mathrm{m}^{-2}$ ou plantas. $\mathrm{m}^{-2}$ ) foi determinada pelo programa após delimitação da superfície interpolada ("clip"). Os bancos de sementes 2000 e 2001 foram colocados na mesma escala para fins de comparação.

\subsubsection{Correlações entre o banco de sementes e a flora emergente}

Correlações entre o banco de sementes e a flora emergente das plantas daninhas foram realizadas pelo teste de "Spearman rank", pois de acordo com Steel \& Torrie (1980) e Cardina et al. (1996) este teste é mais apropriado para dados que não possuem uma distribuição normal. Segundo Johnson et al (1996), Zanin et al. (1998) e Heisel et al. (1996a) as plantas daninhas geralmente não apresentam uma distribuição normal. Este teste é semelhante à análise de correlação linear de "Pearson", porém o teste de "Spearman rank" ordena ("ranqueia") os dados amostrados e correlaciona as ordens dos dados (Steel \& Torrie, 1980).

No caso da correlação entre banco de sementes e flora emergente de plantas daninhas o objetivo do teste de "Spearman rank" foi verificar se existe correlação positiva entre os dois parâmetros, considerando as ordens dos dados e não valores.

\subsection{Resultados e Discussão}

\subsubsection{Emergência do banco de sementes e análises preliminares}

As plantas daninhas tiveram sua emergência em campo variando de 0,08 a 7\% quando se comparou a média de plantas emergidas em campo com a média do banco de 
sementes originário de coleta em janeiro de 2001, como pode ser visto na Tabela 3 . A Commelina benghalensis foi a que possuiu a maior emergência em campo nas duas comparações, sendo seguida pela Ipomoea grandifolia, Leonotis nepetifolia e pela Alternanthera tenella.

Comparando os resultados obtidos no experimento com os de outros autores (Voll et al. 1997ab, Cardina \& Sparrow, 1996) percebe-se que o número de sementes por unidade de área foi menor para todas as plantas daninhas, já que o método de determinação do banco de sementes utilizado não considerou a contagem de sementes restantes no vaso que não emergiram por algum motivo, tais como dormência de sementes, predação e deterioração. Conseqüentemente a porcentagem de emergência determinada foi maior para a maioria das plantas, já que o banco de sementes determinado foi menor. Este método utilizado pode às vezes subestimar o banco de sementes, mas se bem conduzido, é muito mais interessante em termos práticos, pois não contabiliza as sementes dormentes e sua determinação é mais fácil. As plantas daninhas que mais emergiram na cultura da soja foram a Commelina benghalensis, Ageratum conyzoides, Alternanthera tenella e o Panicum maximum consecutivamente (Tabela 1).

Comparando a densidade média do banco de sementes por espécie, houve uma diminuição do número médio de sementes da maioria das espécies de plantas daninhas do ano 2000 paro o ano 2001, sendo provavelmente devido ao controle e manejo das plantas daninhas na entressafra (roçagem e aplicação de glyphosate) realizado que diminuiu a possibilidade das plantas daninhas completarem seus ciclos e produzirem sementes. Este é um tipo de manejo desejável sempre que possível, pois normalmente é o banco de sementes que determina o grau de infestações futuras (Ball, 1992, Martins \& Silva, 1994; Kropff et al. 1999).

Os coeficientes de variação dos dados foram grandes (Tabela 2), variando de 118 a $287 \%$ nos dados do banco de sementes 2001, 105 a 333\% no banco de sementes 2000 e de 140 a $647 \%$ na flora emergente 2000, demonstrando que a variabilidade como porcentagem da média é muito grande para todas as plantas daninhas e seus respectivos bancos de sementes, já indicando algum nível de agregação das plantas no campo. Diversos autores estudando o comportamento dos bancos de sementes das plantas 
daninhas também encontraram altos coeficientes de variação (Benoit et al. 1989; Forcella 1992; Cardina \& Sparrow, 1996).

Tabela 1. Densidade do banco de sementes 2000 (BS00) e 2001(BS01) e emergência da flora daninha (F01) na cultura de soja plantada em março de 2001.

\begin{tabular}{|c|c|c|c|c|}
\hline Espécies & $\begin{array}{c}\text { BS00 } \\
\text { Sementes.m }{ }^{-2}\end{array}$ & $\begin{array}{c}\text { BS01 } \\
\text { Sementes.m }^{-2}\end{array}$ & $\begin{array}{c}\text { F01 } \\
\text { Plantas.m }\end{array}$ & $\begin{array}{c}\text { E \% } \\
\text { BS01/F01 }\end{array}$ \\
\hline Commelina benghalensis & 74,2 & 169,07 & 12,21 & 7,22 \\
\hline Ageratum conyzoides & 869,1 & 637,11 & 4,56 & 0,72 \\
\hline Alternanthera tenella & 178,4 & 68,04 & 1,67 & 2,45 \\
\hline Panicum maximum & 841,2 & 222,68 & 1,53 & 0,69 \\
\hline Leonotis nepetifolia & 112,4 & 46,39 & 1,26 & 2,72 \\
\hline Richardia brasiliensis & 156,7 & 116,49 & 1,03 & 0,88 \\
\hline Ipomoea grandifolia & - & 9,28 & 0,52 & 5,60 \\
\hline Phyllanthus corcovadensis & 102,1 & 172,2 & 0,39 & 0,23 \\
\hline Digitaria sanguinalis & 90,7 & 44,33 & 0,37 & 0,83 \\
\hline Amaranthus viridis & 53,6 & 18,56 & 0,29 & 1,56 \\
\hline Nicandra physaloides & 10,3 & 37,11 & 0,19 & 0,51 \\
\hline Gnaphalium spicatum & 87,6 & 50,52 & 0,04 & 0,08 \\
\hline Eleusine indica & 13,4 & 26,8 & - & - \\
\hline Cyperus rotundus & 5,2 & 8,25 & - & - \\
\hline Digitaria insularis & - & 4,12 & - & - \\
\hline Portulaca oleracea & - & 2,06 & - & - \\
\hline Chamaesyce hirta & 13,4 & - & 0,43 & - \\
\hline Bidens pilosa & - & - & 0,06 & - \\
\hline Tithonia speciosa & - & - & 0,04 & - \\
\hline Euphorbia heterophylla & - & - & 0,02 & - \\
\hline Conyza bonariensis & 24,7 & - & 0,02 & - \\
\hline Solanum americanum & 18,6 & - & - & - \\
\hline Blainvillea rhomboidea & 6,2 & - & - & - \\
\hline Emilia sonchifolia & 6,2 & - & - & - \\
\hline
\end{tabular}

Os altos valores dos coeficientes de variação deveram se certamente à distribuição não uniforme das plantas daninhas e seu respectivo banco de sementes na área estudada, 
que normalmente é mais regra que exceção quando se refere à uma comunidade de plantas (Barbour et al 1987).

Calculando o índice de dispersão (ID) para as quatro plantas daninhas mais abundantes e para o agrupamento das demais em mono e dicotiledôneas foi verificado que todas plantas daninhas (flora e banco de sementes) apresentaram ID muito alto indicando alguma forma de agregação das plantas daninhas emergentes (Tabela 4 e 5). As que possuíam um ID maior foram na seqüência: Commelina benghalensis, Ageratum conyzoides, Alternanthera tenella e o Panicum maximum.

Dentre as classes, as monocotiledôneas tiveram ID maior que o das dicotiledôneas. Para o BS00 as plantas que apresentaram maior ID foram na seqüência Ageratum conyzoides, Alternanthera tenella, Panicum maximum e Commelina benghalensis. E para o BS01 foram Ageratum conyzoides, Commelina benghalensis, Panicum maximum e Alternanthera tenella Nos dois anos de amostragens do banco de sementes as dicotiledôneas tiveram ID maior que o das monocotiledôneas.

Porém este índice só indica a possibilidade de um alto grau de contagiosidade, mas não faz referencia à localização do dado no espaço. Para uma explicação da variabilidade espacial das plantas daninhas, a melhor forma é através do endereçamento das mesmas através de sua posição no espaço, que é perfeitamente possível com a utilização de mapas.

Analisando a normalidade da distribuição das plantas daninhas escolhidas e as duas classes ficou evidente que os dados não possuíram uma distribuição normal com coeficientes de assimetria ("skewness") e curtose ("kurtosis") elevados (Tabela 2 e 3).

Portanto, o teste de correlação de "Spearman rank" apresenta vantagens em relação ao de Pearson em se fazer correlações de amostras muito diferentes, pois este teste considera tendências e não valores. Segundo Cardina et al. (1996) o teste de Pearson é mais sensível a valores extremos o que não acontece com o de "Spearman rank". 
Tabela 2. Estatística descritiva dos dados de contagem do banco de sementes 2000 (BS00), do banco de sementes 2001 (BS01).

\begin{tabular}{lcccccccccccc}
\hline \multicolumn{1}{c}{ BS00 } & $\mu\left(\right.$ Sementes.m $\left.{ }^{-2}\right)$ & $\mathrm{s}$ & $\mathrm{S}^{2}$ & $\mathrm{ID}$ & $\mathrm{CV} \%$ & $\mathrm{~W}$ & & \multicolumn{3}{c}{$\mathrm{S}$} & & $\mathrm{K}$ \\
\hline \multicolumn{1}{c}{ Espécies } & & & & & & & $\mathrm{O}$ & $\mathrm{T}$ & $\mathrm{O}$ & $\mathrm{T}$ & $\mathrm{O}$ & $\mathrm{T}$ \\
A. tenella & 178 & 594 & 352897 & 1979 & 333 & $0,5^{*}$ & $0,6^{*}$ & 5,6 & 2,08 & 38,4 & 0,51 \\
P. maximum & 841 & 882 & 777565 & 924 & 105 & $0,6^{*}$ & $0,7^{*}$ & 1,7 & 0,11 & 4,0 & 0,68 \\
A. conyzoides & 869 & 1405 & 1973443 & 2271 & 162 & $0,7^{*}$ & $0,9^{*}$ & 7,2 & 0,31 & 74,2 & $-0,41$ \\
C. Benghalensis & 74 & 191 & 36327 & 489 & 257 & $0,5^{*}$ & $0,7^{*}$ & 3,2 & 1,79 & 11,5 & 0,89 \\
Monocotiledôneas & 110 & 289 & 83727 & 759 & 262 & $0,2^{*}$ & $0,5^{*}$ & 4,9 & 1,73 & 33,0 & $-0,68$ \\
Dicotiledôneas & 608 & 936 & 877030 & 1442 & 154 & $0,7^{*}$ & $0,9^{*}$ & 5,0 & 0,19 & 40,3 & $-1,08$ \\
\hline \multicolumn{1}{c}{ BS01 } & & & & & & & & & & & \\
\hline A. tenella & 68 & 187 & 35139 & 516 & 276 & $0,4^{*}$ & $0,5^{*}$ & 3,2 & 1,64 & 13,9 & 1,87 \\
P. maximum & 223 & 326 & 106426 & 478 & 147 & $0,5^{*}$ & $0,6^{*}$ & 2,8 & 0,96 & 10,3 & 0,14 \\
A. conyzoides & 637 & 807 & 651051 & 1022 & 127 & $0,5^{*}$ & $0,7^{*}$ & 2,1 & 0,05 & 7,0 & $-0,96$ \\
C. Benghalensis & 169 & 357 & 127536 & 754 & 211 & $0,7^{*}$ & $0,8^{*}$ & 4,3 & 1,24 & 28,9 & 0,79 \\
Monocotiledôneas & 57 & 162 & 26406 & 466 & 287 & $0,1^{*}$ & $0,2^{*}$ & 15,3 & 2,66 & 286,6 & 10,42 \\
Dicotiledôneas & 453 & 536 & 287169 & 635 & 118 & $0,7^{*}$ & $0,7^{*}$ & 3,5 & 0,14 & 22,2 & $-0,37$ \\
\hline
\end{tabular}

Tabela 3. Estatística descritiva dos dados de contagem da flora emergente 2001 (F01).

\begin{tabular}{lccccccccccc}
\hline \multicolumn{1}{c}{ Espécies } & $\mu\left(\right.$ Plantas. $\left.^{-2}\right)$ & $\mathrm{s}$ & $\mathrm{s}^{2}$ & $\mathrm{ID}$ & $\mathrm{CV} \%$ & $\mathrm{~W}$ & \multicolumn{3}{c}{$\mathrm{S}$} & \multicolumn{2}{c}{$\mathrm{K}$} \\
\hline \multirow{2}{*}{ A. tenella } & & & & & & $\mathrm{O}$ & $\mathrm{T}$ & $\mathrm{O}$ & $\mathrm{T}$ & $\mathrm{O}$ & $\mathrm{T}$ \\
P. maximum & 1,7 & 4,6 & 21,0 & 12,6 & 274 & $0,3^{*}$ & $0,5^{*}$ & 3,9 & 2,3 & 18,3 & 4,94 \\
A. conyzoides & 1,5 & 2,8 & 8,1 & 5,3 & 187 & $0,8^{*}$ & $0,9^{*}$ & 2,1 & 1,4 & 5,2 & 0,79 \\
C. Benghalensis & 4,6 & 8,4 & 70,7 & 15,5 & 185 & $0,5^{*}$ & $0,9^{*}$ & 3,2 & 1,1 & 12,9 & 0,84 \\
Monocotiledôneas & 12,2 & 17,7 & 314,8 & 25,8 & 145 & $0,4^{*}$ & $0,5^{*}$ & 2,4 & 0,4 & 7,1 & $-0,79$ \\
Dicotiledôneas & 0,4 & 2,4 & 5,7 & 15,3 & 641 & $0,4^{*}$ & $0,5^{*}$ & 8,3 & 6,3 & 74,3 & 43,59 \\
& 4,3 & 6,1 & 37,0 & 8,6 & 141 & $0,6^{*}$ & $0,7^{*}$ & 1,7 & 1,2 & 3,5 & 1,38 \\
\hline
\end{tabular}

* $1 \%$ de significância pelo teste de Shapiro Wilk`s (W); $\mathrm{S}$ - assimetria (simetria: números próximos a unidade), O (Dados originais), T (Dados transformados); K-Curtose (próxima de zero, dados tendendo a normalidade); ID - Índice de dispersão, s - desvio padrão, s² - variância, CV\% - Coeficiente de variação. 


\subsubsection{Estrutura espacial da população das plantas daninhas}

As populações, tanto do banco de sementes quanto da flora emergente, das plantas daninhas apresentaram uma distribuição de freqüência do tipo log normal. Desta forma os dados brutos de contagem na grade foram previamente transformados no sentido de normalizar os dados e amenizar a influência de valores extremos antes da análise espacial. Como no estudo da variabilidade espacial das plantas daninhas é questionada a retirada de dados extremos, candidatos a "outliers", antes da análise espacial como feito por Libardi et al. (1986) no estudo da umidade do solo utilizando a técnica dos quartis, é sempre interessante amenizar esta anormalidade através da transformação log para dados com distribuição do tipo log.

Apesar do teste de "Shapiro Wilk's" ter sido significativo em todos os casos os dados após transformação apresentaram uma melhor assimetria e curtose, com exceção da flora (2001) e do banco de sementes (2001) das monocotiledôneas e a flora (2001) da Alternanthera tenella (Tabela 2 e 3). Porém, segundo Journel (1989) e Trangmar et al. (1985) muitos fenômenos naturais que não apresentam esta normalidade dos dados podem apresentar uma dependência espacial muito clara quando são submetidos à análise espacial com a utilização de semivariogramas. Os autores ressaltaram também que novas ferramentas já estavam sendo desenvolvidas para melhorar o estudo de dados com distribuição não normal, além de que diversos autores já realizaram interpolações por "krigagem" com dados não normais em plantas daninhas, obtendo sucesso.

$\mathrm{Na}$ análise dos semivariogramas foi possível o ajuste de modelos tanto ao banco de sementes quanto à flora emergente das quatro espécies escolhidas. Nas classes mono e dicotiledôneas não foram possíveis o ajuste de modelos aos bancos de sementes em nenhum dos dois anos, portanto, na interpolação para a geração dos mapas foram utilizados os mesmos parâmetros do modelo ajustado à flora emergente das dicotiledôneas.

Para as quatro espécies estudadas houve uma dependência espacial das amostras quando se utilizou os dados das duas grades ( $20 \times 20$ e 6 × 6 m), sendo os modelos, de modo geral, bem ajustados aos dados. 
Não foi possível a deteç̧ão de dependência espacial quando se utilizou somente a grade de $20 \times 20 \mathrm{~m}$ para a determinação do banco de sementes (BS00) coletado em junho de 2000, demonstrando que as amostragens dos bancos de sementes das plantas daninhas estudadas não são correlacionadas nesta escala de estudo. Portanto para a interpolação dos dados do banco de sementes do ano de 2000 para a geração dos mapas foram utilizados os parâmetros dos modelos ajustados no ano 2001, já que houve uma detecção de dependência espacial entre as amostras para a maioria das plantas estudadas.

\subsubsection{Análises dos semivariogramas das plantas daninhas}

Para a Alternanthera tenella a distância máxima ou o alcance, que as amostras possuíram dependência entre si foi de $11 \mathrm{~m}$ para a flora emergente (Figura 3A e Tabela 4) e de 14 metros para o banco de sementes (Figura 4A e Tabela 4). Portanto avaliações ou amostragens feitas numa distância maior que este alcance são independentes entre si, pois a semivariância é igual à variância experimental implicando em variação aleatória ou ao acaso (Trangmar et al., 1985).

$\mathrm{O}$ alcance também se refere ao raio máximo de influencia da estimativa de um ponto por "krigagem" (Vieira et al., 1983).

A)

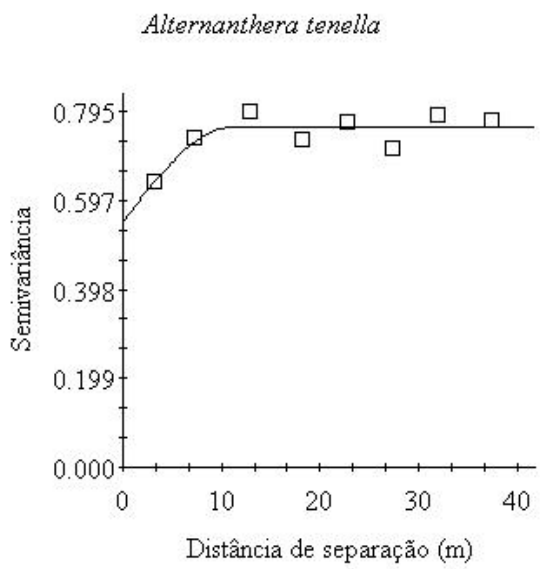

B)

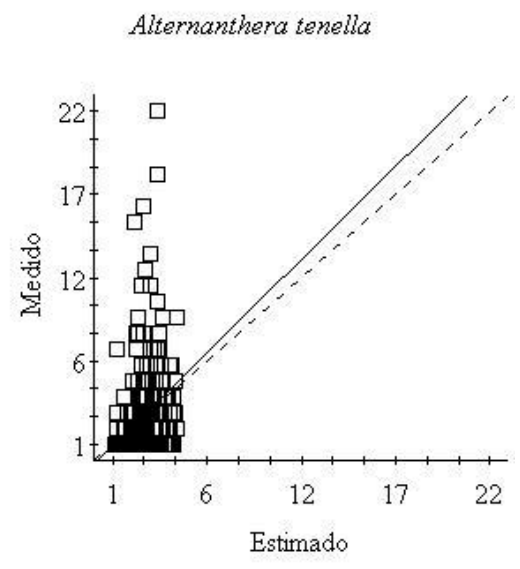

Figura 3 - Semivariograma ajustado para a flora emergente (2001) de Alternanthera tenella (A) e seu respectivo gráfico de dispersão da validação cruzada (B) realizada para os dados resultantes da interpolação por "krigagem" em 2001 
A)

Alternanthera tenella

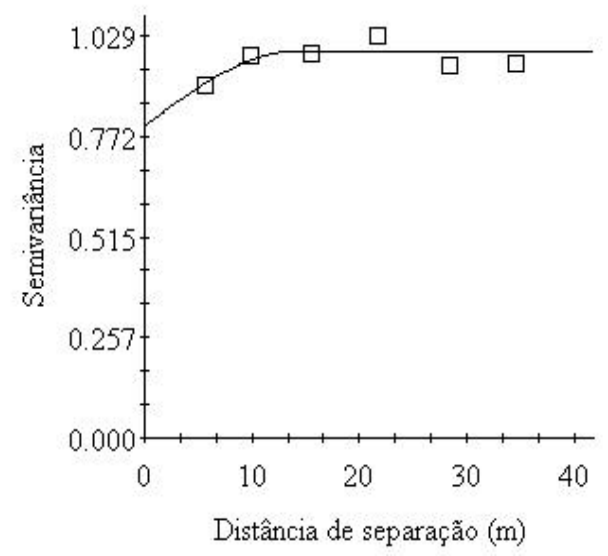

B)

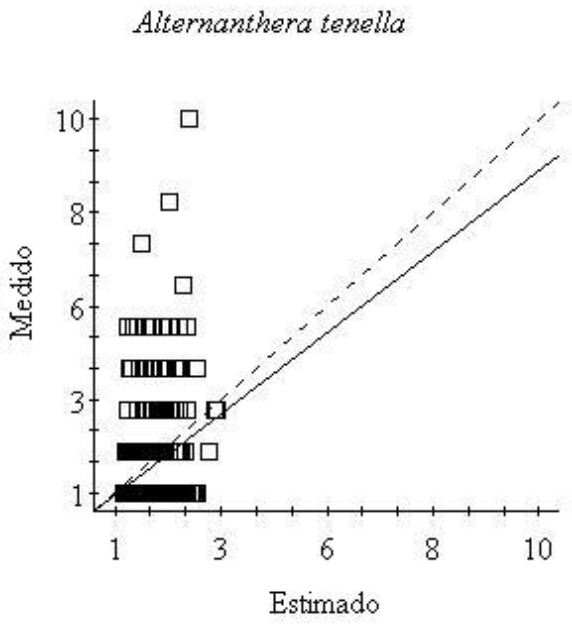

Figura 4 - Semivariograma ajustado para o banco de sementes (2001) de Alternanthera tenella (A) e seu respectivo gráfico de dispersão da validação cruzada (B) realizada para os dados resultantes da interpolação por "krigagem” em 2001.

Tabela 4. Parâmetros dos semivariogramas ajustados ao modelo esférico e validação cruzada realizada pelos dados interpolados para Alternanthera tenella.

\begin{tabular}{|c|c|c|c|c|c|c|c|c|}
\hline Espécie & Ano & Semivariograma & Alcance & Patamar & Intercepto & $\mathrm{r}^{2}$ & NMP & $\mathrm{A} \%$ \\
\hline & 2000 & $\mathrm{BS}$ & - & - & - & - & - & - \\
\hline \multirow[t]{2}{*}{ A. tenella } & 2001 & $\mathrm{BS}$ & 14 & 0,99 & 0,75 & 0,551 & 557 & 24 \\
\hline & 2001 & Flora & 11 & 0,76 & 0,55 & 0,711 & 52 & 27 \\
\hline \multirow[t]{2}{*}{$\begin{array}{l}\text { Espécie ou } \\
\text { classe }\end{array}$} & Ano & $\begin{array}{l}\text { Validação } \\
\text { cruzada }\end{array}$ & \multicolumn{2}{|c|}{$\begin{array}{l}\text { Coeficiente de } \\
\text { regressão }\end{array}$} & \multicolumn{3}{|c|}{$\begin{array}{c}\text { Desvio padrão da } \\
\text { predição }\end{array}$} & $\mathrm{r}^{2}$ \\
\hline & 2000 & $\mathrm{BS}$ & & - & & - & & - \\
\hline \multirow[t]{2}{*}{ A. tenella } & 2001 & $\mathrm{BS}$ & & 0,86 & & 0,12 & & 0,09 \\
\hline & 2001 & Flora & & 1,08 & & 0,09 & & 0,21 \\
\hline
\end{tabular}

NMP - Número mínimo de pares de pontos utilizados para estimar os pontos do semivariograma, $\mathrm{r}^{2}$ é a proporção da variação explicada pelo melhor ajuste do modelo, A\% (autocorrelação) é a proporção da variação explicada pela distância entre as amostras. $\mathrm{A} \%=$ (patamar-intercepto)/patamar*(100). 
Pode se perceber também que o banco de sementes possuiu uma dependência espacial semelhante à flora emergente, esta informação é importante, pois é um indicativo de que a variabilidade espacial da flora emergente e seu respectivo banco de sementes podem ter correlações espaciais e que respondem da mesma forma ao micro ambiente.

O banco de sementes da Alternanthera tenella possuiu um maior alcance que sua flora emergente demonstrando que a dependência espacial do banco de sementes se dá numa distância superior à sua flora. Trabalho semelhante feito por Cardina et al. (1996), estudando a dinâmica espacial da planta Chenopodium album, encontrou em três anos consecutivos o mesmo fenômeno de uma dependência maior do banco de sementes em relação à sua flora emergente.

Analisando a autocorrelação (A\%) existente entre amostras separadas por uma determinada distância para a Alternanthera tenella, cerca de 27 e $24 \%$ para a flora e banco respectivamente, de toda variação existente é dependente da distância de amostragem. Estes valores de autocorrelação existentes em amostras separadas por uma dada distância são obtidos pela proporção da diferença entre o patamar e o intercepto como proporção do patamar. $\mathrm{O}$ valor do intercepto corresponde à quantidade de variação devido à escala de estudo utilizada ou devido a erro amostral. Se a autocorrelação for muito baixa ou nula em diferentes escalas de observação pode se dizer que a média é um bom estimador do fenômeno em estudo. Para a comparação entre erros atribuídos à amostragem alguns autores representam o intercepto como porcentagem do patamar (Trangmar et al., 1985).

Analisando a validação cruzada para a flora emergente (Figura 3B) percebe-se que o modelo subestimou um pouco a infestação, portanto o mapa resultante da "krigagem" teve sua superfície de infestação subestimada. Na interpolação para o banco de sementes ocorreu o inverso, pois há uma concentração de pontos abaixo da reta 1:1, ou seja, os valores estimados foram maiores que os medidos, portanto o modelo ajustado superestimou a infestação na interpolação (Figura 4B). 
A distância máxima ou o alcance para o Panicum maximum onde as amostras possuíram dependência entre si foi de $7 \mathrm{~m}$ para a flora emergente (Figura 5A e Tabela 5) e de 8 metros para o banco de sementes (Figura 5B e Tabela 5).

A)

Panicum maximum

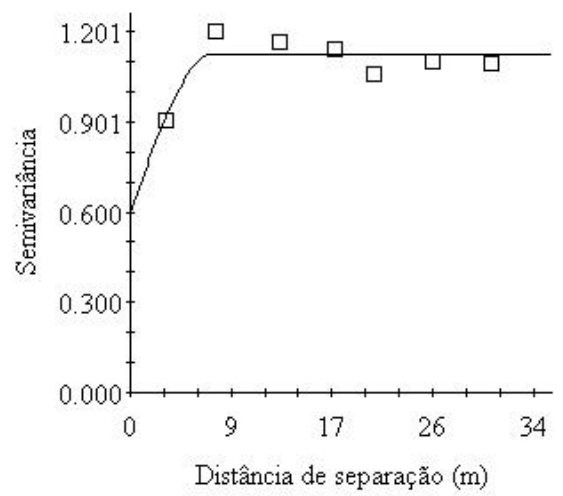

B)

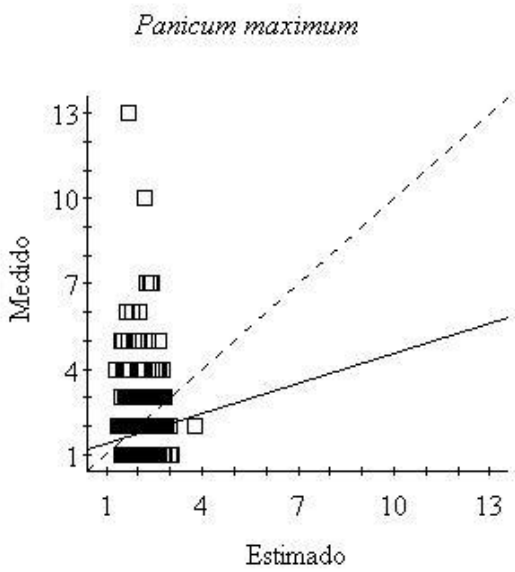

Figura 5 - Semivariograma ajustado para a flora emergente (2001) de Panicum maximum (A) e seu respectivo gráfico de dispersão da validação cruzada (B) realizada para os dados resultantes da interpolação por "krigagem” em 2001

A)

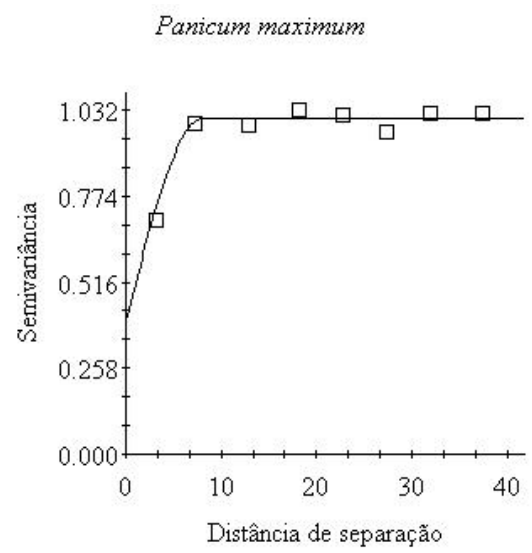

B)

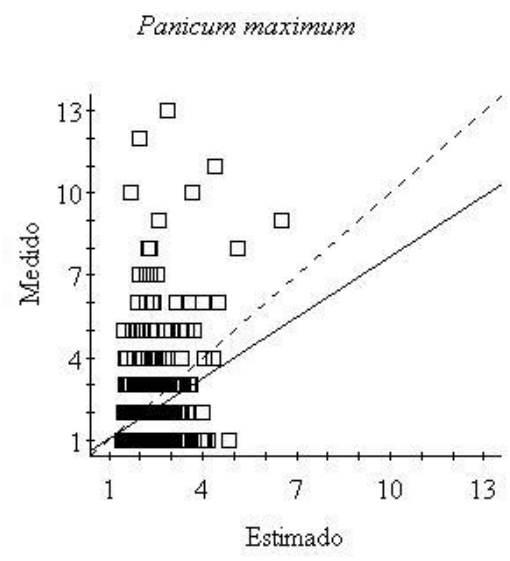

Figura 6 - Semivariograma ajustado para o banco de sementes (2001) de Panicum maximum (A) e seu respectivo gráfico de dispersão da validação cruzada (B) realizada para os dados resultantes da interpolação por "krigagem” em 2001. 
Tabela 5. Parâmetros dos semivariogramas ajustados ao modelo esférico e validação cruzada realizada pelos dados interpolados para Panicum maximum.

\begin{tabular}{|c|c|c|c|c|c|c|c|c|}
\hline Espécie & Ano & Semivariograma & Alcance & Patamar & Intercepto & $\mathrm{r}^{2}$ & NMP & $\mathrm{A} \%$ \\
\hline & 2000 & BS & - & - & - & - & - & - \\
\hline \multirow[t]{2}{*}{ P. maximum } & 2001 & $\mathrm{BS}$ & 8 & 0,99 & 0,40 & 0,963 & 52 & 59 \\
\hline & 2001 & Flora & 7 & 1,10 & 0,60 & 0,846 & 47 & 45 \\
\hline \multirow[t]{2}{*}{ Espécie } & Ano & Validação cruzada & \multicolumn{2}{|c|}{$\begin{array}{l}\text { Coeficiente de } \\
\text { regressão }\end{array}$} & \multicolumn{3}{|c|}{$\begin{array}{c}\text { Desvio padrão da } \\
\text { predição }\end{array}$} & $\mathrm{r}^{2}$ \\
\hline & 2000 & $\mathrm{BS}$ & & - & & - & & - \\
\hline \multirow[t]{2}{*}{ P. maximum } & 2001 & $\mathrm{BS}$ & & 0,76 & & 0,13 & & 0,06 \\
\hline & 2001 & Flora & & 0,35 & & 0,15 & & 0,01 \\
\hline
\end{tabular}

NMP - Número mínimo de pares de pontos utilizados para estimar os pontos do semivariograma, $\mathrm{r}^{2}$ é a proporção da variação explicada pelo melhor ajuste do modelo, A\% (autocorrelação) é a proporção da variação explicada pela distância entre as amostras (A\%= patamar-intercepto/patamar*100).

Pode se perceber também que o banco de sementes possuiu uma dependência espacial semelhante à flora emergente e também a uma distância superior. Analisando a autocorrelação (A\%) para a flora de Panicum maximum cerca de $45 \%$ de toda variação é dependente da distância de amostragem e 59\% para o banco de sementes da mesma planta daninha. Demonstrando uma melhor estimação de densidade de plantas e sementes utilizando interpoladores que consideram a dependência espacial entre amostras, como a "krigagem".

$\mathrm{Na}$ validação cruzada para a flora emergente de Panicum maximum (Figura 5B) percebe-se que o modelo superestimou mais que para a Alternanthera tenella, portanto o mapa resultante da "krigagem" terá áreas estimadas com uma maior infestação, ou um maior número de plantas de Panicum maximum. O mesmo aconteceu com o banco de sementes. $\mathrm{Na}$ "krigagem" os pontos estimados de densidade próximos de zero na realidade são acrescidos de mais plantas e pontos com um número muito alto de plantas 
tem sua densidade diminuída, esta suavização é característica do método de interpolação (Isaaks \& Srivastava, 1989) quando se tem dados muito discrepantes, porém é melhor do que considerar uma densidade média ou utilizar interpoladores que não consideram a dependência espacial existente. Em certos casos esta suavização, citada pelos pesquisadores em ciência do solo principalmente, é até bem vista se pensarmos em infestações de plantas daninhas, principalmente do banco de sementes, que sem dúvida é muito mais susceptível a vários erros decorrentes da amostragem e nas etapas subseqüentes como na determinação do mesmo por emergência ou por separação e contagem de sementes. Portanto, alguns pontos vizinhos muito diferentes obtidos na determinação do banco de sementes podem ser decorrentes de problemas, tais como: deterioração, predação, condições dentro da casa de vegetação, erro de contagem de sementes, e não do fenômeno de variabilidade espacial do banco de sementes das plantas daninhas.

O alcance para o Ageratum conyzoides foi de $9 \mathrm{~m}$ para a flora emergente (Figura 7A e Tabela 6) e de 11 metros para o banco de sementes (Figura 8A e Tabela 6).

A)

Ageratum conyzoides

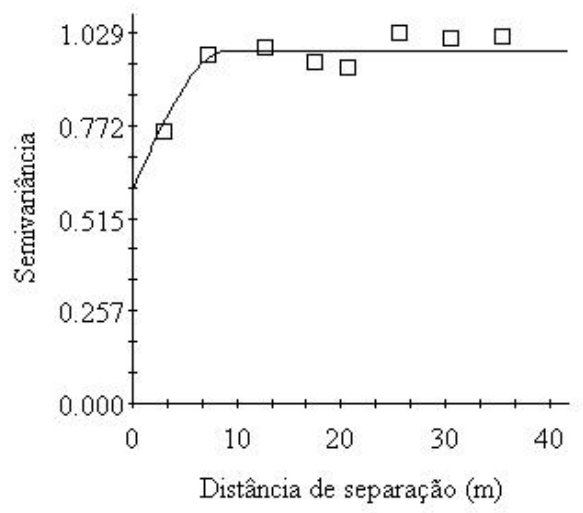

B)

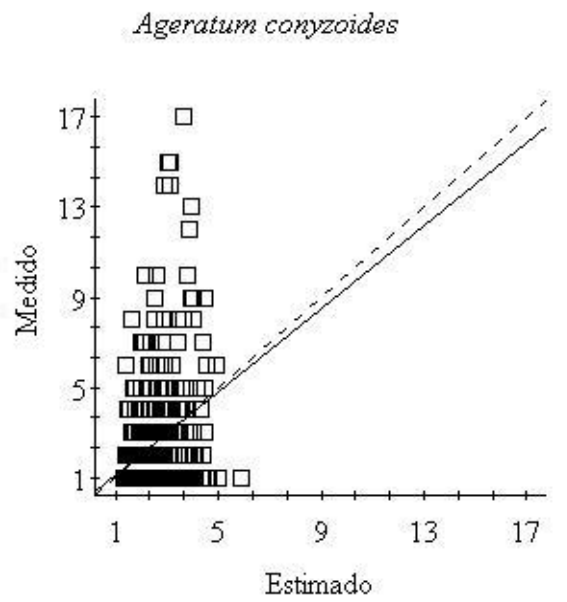

Figura 7 - Semivariograma ajustado para a flora emergente (2001) de Ageratum conyzoides (A) e seu respectivo gráfico de dispersão da validação cruzada (B) realizada para os dados resultantes da interpolação por "krigagem" em 2001 
A)

Ageratum conyzoides

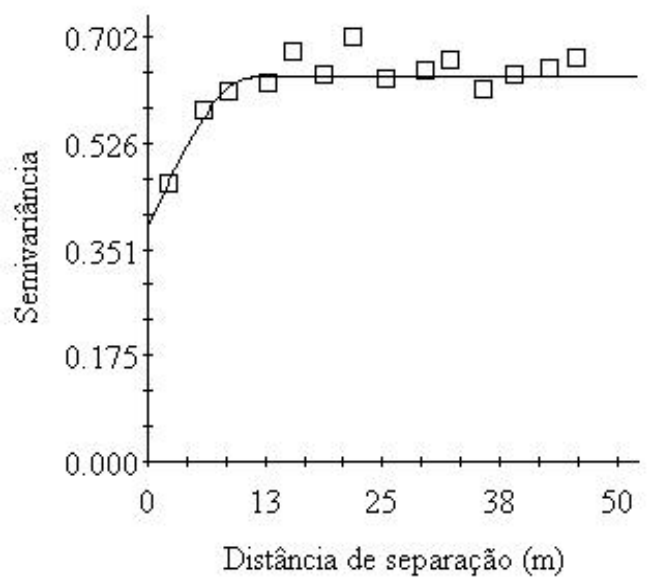

B)

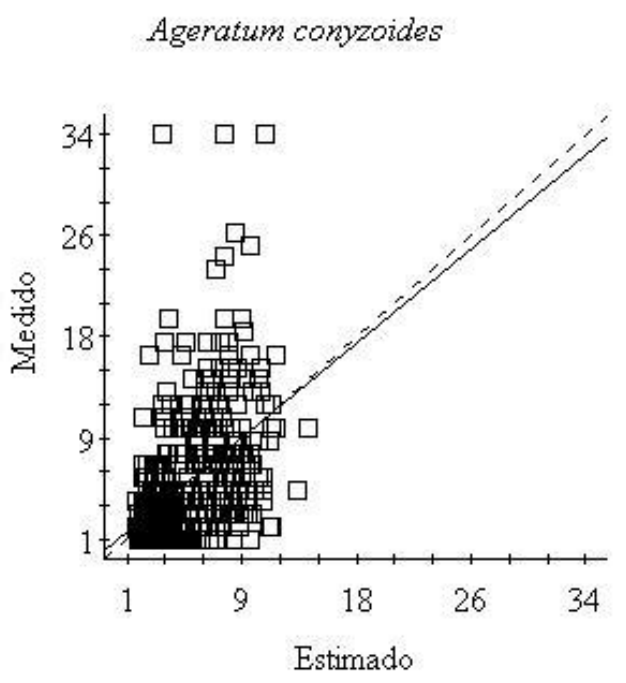

Figura 8 - Semivariograma ajustado para o banco de sementes (2001) de Ageratum conyzoides (A) e seu respectivo gráfico de dispersão da validação cruzada (B) realizada para os dados resultantes da interpolação por "krigagem" em 2001

Tabela 6. Parâmetros dos semivariogramas ajustados ao modelo esférico e validação cruzada realizada pelos dados interpolados para Ageratum conyzoides.

\begin{tabular}{ccccccccc}
\hline Espécie & Ano & Semivariograma & Alcance & Patamar & Intercepto & $\mathrm{r}^{2}$ & NMP & A\% \\
\hline \multirow{3}{*}{ A. conyzoides } & 2000 & BS & - & - & - & - & - & - \\
& 2001 & BS & 11 & 0,63 & 0,39 & 0,852 & 47 & 38 \\
& 2001 & Flora & 9 & 0,98 & 0,60 & 0,848 & 27 & 38
\end{tabular}

\begin{tabular}{cccccc}
\hline Espécie & Ano & Validação cruzada & Coeficiente de regressão & $\begin{array}{c}\text { Desvio padrão da } \\
\text { predição }\end{array}$ & $\mathrm{r}^{2}$ \\
\hline \multirow{3}{*}{ A. conyzoides } & 2000 & BS & & - & - \\
& 2001 & BS & 0,93 & 0,07 & 0,23 \\
& 2001 & Flora & 0,92 & 0,13 & 0,08 \\
\hline
\end{tabular}

NMP - Número mínimo de pares de pontos utilizados para estimar os pontos do semivariograma, $\mathrm{r}^{2}$ é a proporção da variação explicada pelo melhor ajuste do modelo, A\% (autocorrelação) é a proporção da variação explicada pela distância entre as amostras (A\%= patamar-intercepto/patamar*100). 
O banco de sementes de Ageratum conyzoides possuiu uma dependência espacial semelhante à flora emergente. E novamente o banco de sementes possuiu um alcance a uma distância superior ao da flora emergente.

A autocorrelação (A\%) para a flora e banco de sementes de Ageratum conyzoides foi de $38 \%$; sendo que, o modelo ajustado ao banco de sementes obteve um melhor ajuste do que o obtido para a flora emergente.

Analisando a validação cruzada para a flora emergente (Figura 7B) e para o banco de sementes (Figura 8B) percebe-se que os modelos foram convenientemente bem explicados ou ajustados, portanto o mapa resultante da "krigagem" terá áreas com uma melhor estimativa, tanto para a flora emergente quanto para o banco de sementes.

O alcance para a Commelina benghalensis foi de $15 \mathrm{~m}$ para a flora emergente (Figura 9A e Tabela 7) e de 7 metros para o banco de sementes (Figura 10A e Tabela 7).

A)

Commelina benghalensis

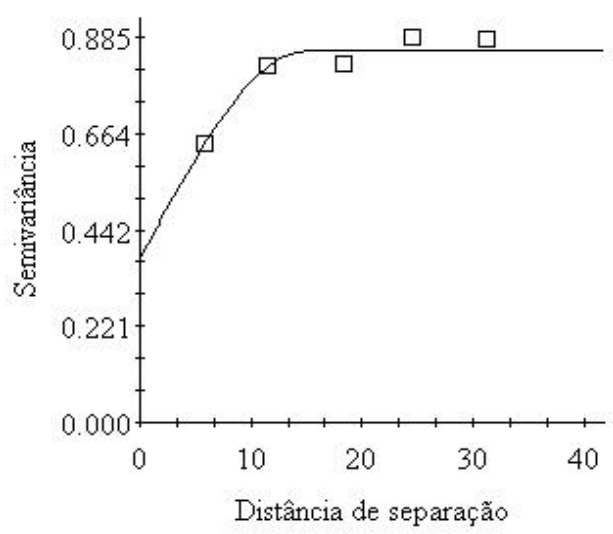

B)

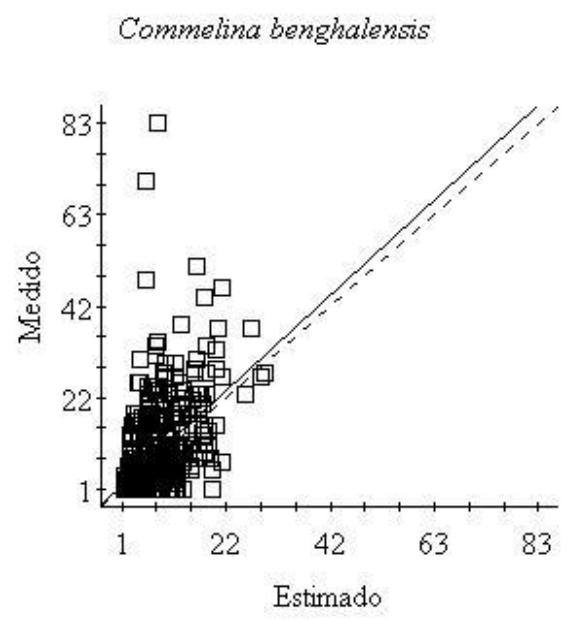

Figura 9 - Semivariograma ajustado para a flora emergente (2001) de Commelina benghalensis e seu respectivo gráfico de dispersão da validação cruzada realizada para os dados resultantes da interpolação por "krigagem" em 2001 
A)

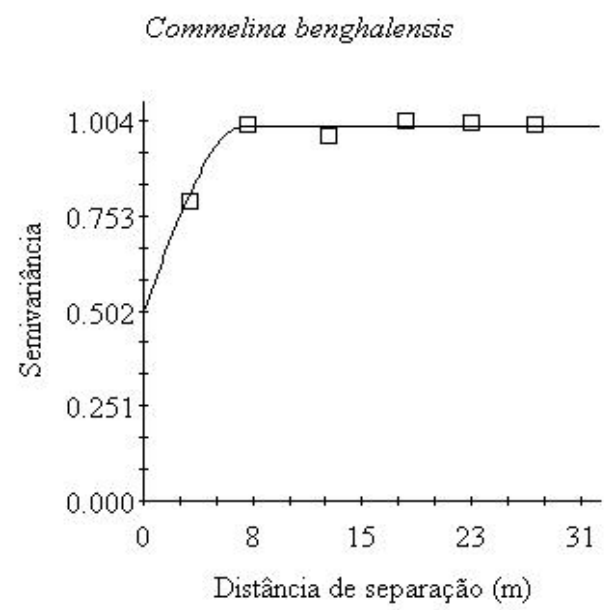

B)

\section{Commelina benghalensis}

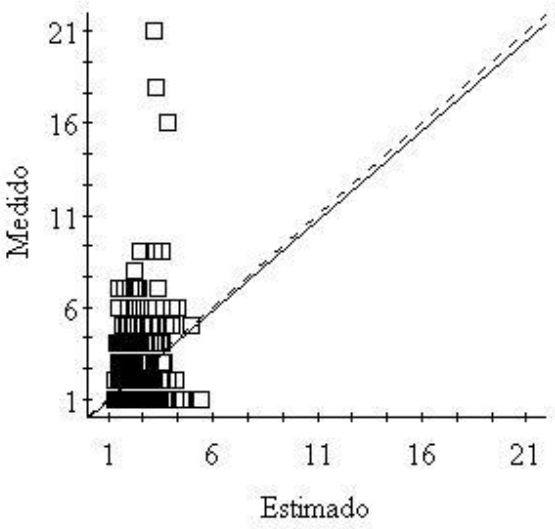

Figura 10 - Semivariograma ajustado para o banco de sementes (2001) de Commelina benghalensis (A) e seu respectivo gráfico de dispersão da validação cruzada (B) realizada para os dados resultantes da interpolação por "krigagem” em 2001

Tabela 7. Parâmetros dos semivariogramas ajustados ao modelo esférico e validação cruzada realizada pelos dados interpolados para Commelina benghalensis.

\begin{tabular}{ccccccccc}
\hline Espécie & Ano & Semivariograma & Alcance & Patamar & Intercepto & $\mathrm{r}^{2}$ & NMP & A\% \\
\hline \multirow{3}{*}{ C. benghalensis } & 2000 & BS & - & - & - & - & - & - \\
& 2001 & BS & 7 & 0,99 & 0,50 & 0,971 & 52 & 50 \\
& 2001 & Flora & 15 & 0,85 & 0,38 & 0,939 & 634 & 55
\end{tabular}

\begin{tabular}{cccccc}
\hline Espécie & Ano & Validação cruzada & Coeficiente de regressão & $\begin{array}{c}\text { Desvio padrão da } \\
\text { predição }\end{array}$ & $\mathrm{r}^{2}$ \\
\hline \multirow{3}{*}{ C.benghalensis } & 2001 & BS & - & - & - \\
& 2001 & Flora & 0,98 & 0,14 & 0,09 \\
& 2001,04 & 0,08 & 0,24 \\
\hline
\end{tabular}

NMP - Número mínimo de pares de pontos utilizados para estimar os pontos do semivariograma, $\mathrm{r}^{2}$ é a proporção da variação explicada pelo melhor ajuste do modelo, A\% (autocorrelação) é a proporção da variação explicada pela distância entre as amostras (A\%= patamar-intercepto/patamar*100). 
Analisando a Commelina benghalensis, o seu banco de sementes possuiu uma dependência espacial diferente da flora emergente possuindo um alcance a uma distância inferior ao da flora emergente. Mostrando que o banco de sementes possuiu uma dependência espacial numa escala menor que a respectiva flora emergente.

A autocorrelação (A\%) para as amostras da flora emergente de Commelina benghalensis foi de 55\% e 50\% para o banco de sementes.

$\mathrm{Na}$ validação cruzada para a flora emergente (Figura 9B) percebe-se que o modelo também foi eficiente na estimação dos dados, portanto o mapa resultante da "krigagem" terá áreas estimadas adequadamente. O banco de sementes também foi bem estimado (Figura 10B), porém a flora emergente foi mais consistente.

A flora emergente das plantas agrupadas na classe monocotiledôneas não foi ajustada a modelos, pois sua freqüência foi muito baixa, sendo representada apenas pela planta Digitaria sanguinalis, portanto sua interpolação foi feita pelos parâmetros do banco de sementes que tiveram um alcance de 9 metros para o banco de sementes (Figura 11A e Tabela 8).

A)

Monocotiledôneas

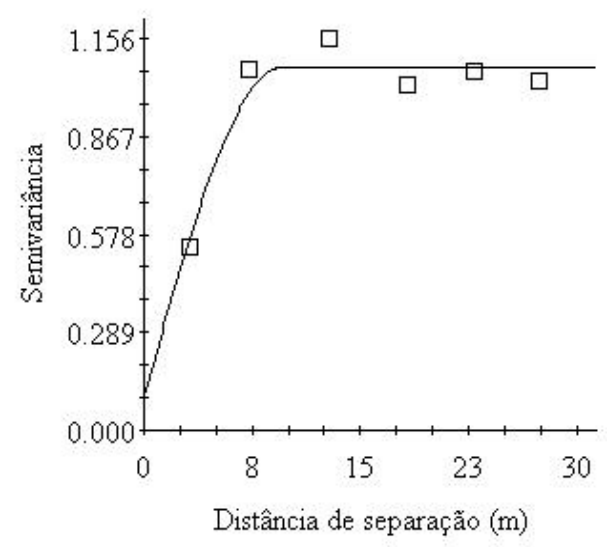

B)

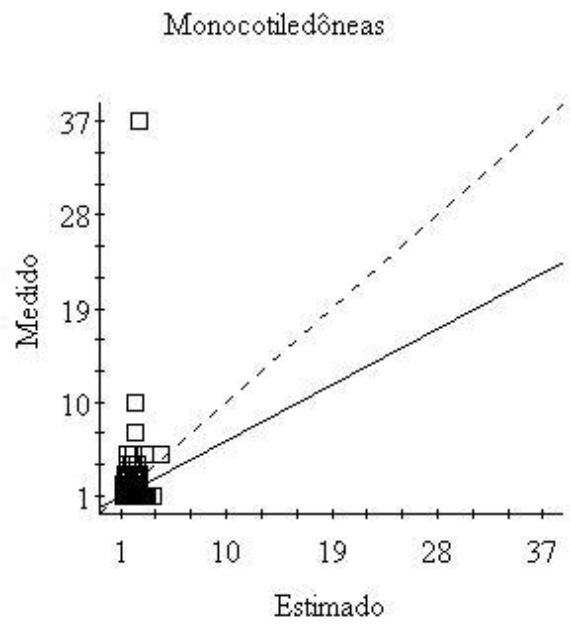

Figura 11 - Semivariograma ajustado para o banco de sementes (2001) das plantas monocotiledôneas (A) e seu respectivo gráfico de dispersão da validação cruzada (B) realizada para os dados resultantes da interpolação por "krigagem" em 2001. 
Já as dicotiledôneas tiveram somente o alcance de $7 \mathrm{~m}$ determinado pela modelagem do semivariograma à flora emergente (Figura 12A), não sendo detectada uma dependência espacial nesta escala estudada para o banco de sementes. Portanto nesta escala o banco de sementes das plantas dicotiledôneas não demonstraram uma dependência espacial.

A)

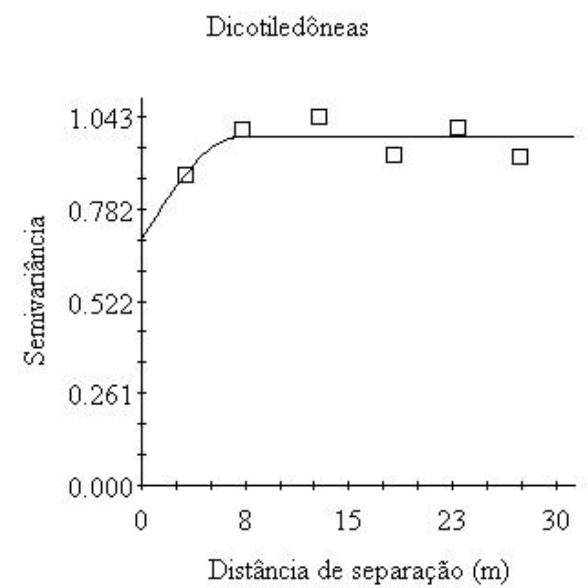

B)

Dicotiledôneas

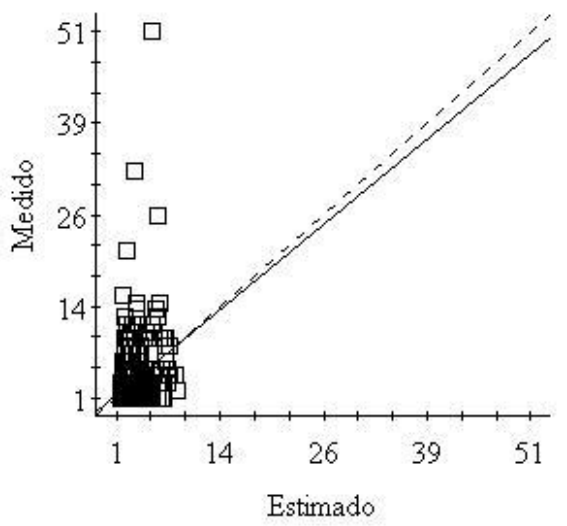

Figura 12 - Semivariograma ajustado para a flora emergente (2001) das classes das plantas daninhas dicotiledôneas (A) e seu respectivo gráfico de dispersão da validação cruzada (B) realizada para os dados resultantes da interpolação por "krigagem” em 2001

O banco de sementes (2001) das monocotiledôneas possuiu uma dependência espacial até um alcance de $9 \mathrm{~m}$. A autocorrelação (A\%) para as amostras da flora emergente das monocotiledôneas foi de $90 \%$ para o banco de sementes. Para a flora de dicotiledôneas a autocorrelação entre as amostras foi de $29 \%$.

$\mathrm{Na}$ validação cruzada para o banco de sementes (Figura 11B) percebe-se que os modelos possíveis de ajuste superestimaram tanto o banco de sementes das monocotiledôneas quanto a flora emergente das dicotiledôneas 2001. O mapa resultante da "krigagem" terá áreas estimadas com um maior número de plantas tanto da classe mono quanto dicotiledôneas. 
Tabela 8. Parâmetros dos semivariogramas ajustados ao modelo esférico e validação cruzada realizada pelos dados interpolados para as classes mono e dicotiledôneas.

\begin{tabular}{|c|c|c|c|c|c|c|c|c|}
\hline Espécie & Ano & Semivariograma & Alcance & Patamar & Intercepto & $\mathrm{r}^{2}$ & NMP & $\mathrm{A} \%$ \\
\hline & 2000 & $\mathrm{BS}$ & - & - & - & - & - & - \\
\hline \multirow[t]{3}{*}{ Monocotiledôneas } & 2001 & BS & 9 & 1,07 & 0,10 & 0,01 & 52 & 90 \\
\hline & 2001 & Flora & - & - & - & - & - & - \\
\hline & 2000 & BS & - & - & - & - & - & - \\
\hline \multirow[t]{2}{*}{ Dicotiledôneas } & 2001 & BS & - & - & - & - & - & - \\
\hline & 2001 & Flora & 7 & 0,99 & 0,7 & 0,01 & 52 & 29 \\
\hline \multirow[t]{2}{*}{ Espécie } & Ano & Validação cruzada & \multicolumn{3}{|c|}{ Coeficiente de regressão } & \multicolumn{2}{|c|}{$\begin{array}{l}\text { Desvio padrão da } \\
\text { predição }\end{array}$} & $\mathrm{r}^{2}$ \\
\hline & 2000 & BS & & - & & - & & - \\
\hline \multirow[t]{3}{*}{ Monocotiledôneas } & 2001 & $\mathrm{BS}$ & & 0,58 & & 0,11 & & 0,05 \\
\hline & 2001 & Flora & & - & & - & & - \\
\hline & 2000 & $\mathrm{BS}$ & & - & & - & & - \\
\hline \multirow[t]{2}{*}{ Dicotiledôneas } & 2001 & BS & & - & & - & & - \\
\hline & 2001 & Flora & & 0,93 & & 0,14 & & 0,08 \\
\hline
\end{tabular}

NMP - Número mínimo de pares de pontos utilizados para estimar os pontos do semivariograma, $\mathrm{r}^{2}$ é a proporção da variação explicada pelo melhor ajuste do modelo, A\% (autocorrelação) é a proporção da variação explicada pela distância entre as amostras (A\%= patamar-intercepto/patamar*100).

Analisando conjuntamente os alcances de todas espécies estudadas e das duas classes (mono e dicotiledôneas) estudadas, percebeu-se que o alcance ("range") variou de 7 a $15 \mathrm{~m}$. Portanto, estudos de correlações espaciais entre plantas daninhas (flora e banco de sementes) e outras variáveis, tais como, fertilidade, umidade e produtividade não devem ser feitos com grades maiores que $15 \mathrm{~m}$, pois corre-se o risco de se perder informações quanto à dependência espacial. Utilizando grade regular de (15 x $15 \mathrm{~m})$ é inviável atualmente um levantamento em áreas extensas, porém o embasamento e conhecimento de correlações espaciais entre variáveis devem ser conduzidas primeiramente em grades detalhadas, para se conhecer o comportamento espacial das 
plantas daninhas, antes de se tomar decisões de manejo utilizando grades não representativas do fenômeno.

\subsubsection{Correlações entre o banco de sementes e a flora emergente}

Quando se comparou o banco de sementes coletado em janeiro de 2001 com a flora emergente coletada no estágio V3 - V4 da soja plantada em março de 2001 (BS01/F01), os coeficientes de correlações de "Spearman rank" foram significativos somente para as plantas daninhas Ageratum conyzoides e Commelina benghalensis, utilizando para a correlação os dados originais amostrais. Como este teste analisa a hipótese da nulidade de que as ordens dos dados não possuem correlação, sua significância para as duas plantas daninhas (A. conyzoides e C. benghalensis) mostra que houve uma correlação entre o banco de sementes e a flora emergente com coeficientes de correlação de 0,32 para a C. benghalensis e 0,26 para o A.conyzoides (Tabela 9). Os coeficientes de determinação (coeficiente de correlação ao quadrado) sugerem que 10\% (C. benghalensis) e 6\% (A.conyzoides) da variação da flora emergente foi atribuída à variação do banco de sementes.

Tabela 9. Correlação de Spearman rank como medida de comparação do banco de sementes coletado em junho de 2000 em janeiro de 2001 com a Flora emergente em abril de 2001.

\begin{tabular}{lccc}
\hline Espécies e classes & BS01/F01 & BS00/F01 & BS00/BS01 \\
\hline A. tenella & 0,12 & $0,38^{*}$ & 0,06 \\
P. maximum & 0,03 & $-0,02$ & $-0,01$ \\
A. conyzoides & $0,32^{*}$ & $0,18^{*}$ & $0,27^{*}$ \\
C. benghalensis & $0,26^{*}$ & $0,13^{*}$ & $0,13^{*}$ \\
Monocotiledôneas & 0,08 & $0,15^{*}$ & $0,13^{*}$ \\
Dicotiledôneas & 0,03 & 0,07 & $0,17^{*}$ \\
\hline
\end{tabular}

* Coeficientes significantes ao nível de 5\% 
Comparando a flora daninha emergida em 2001(BS00/F01) com o banco de sementes coletado em junho de 2000, somente o Panicum maximum e as dicotiledôneas não tiveram a correlação significativa. Altas correlações obtidas entre os bancos de sementes mostram que pode existir a possibilidade de regiões de alta infestação de sementes de um ano persistir no tempo.

Quando se comparou os dois bancos de sementes, coletados em junho de 2000 e em janeiro de 2001, percebeu-se que somente o $A$. conyzoides e a classe dicotiledôneas tiveram suas correlações significativas.

Dentre todas as plantas daninhas estudadas as que melhor representaram sua estabilidade temporal foram o Ageratum conyzoides e a Commelina benghalensis, que possuíram um coeficiente de correlação significativo para as três comparações feitas (BS00/BS01; BS01/F01 e BS00/F01).

Este caráter de estabilidade é muito importante já que para medidas de manejo utilizando técnicas de agricultura de precisão via mapeamento, a previsão de infestação no planejamento prévio do manejo e controle é uma estratégia muito importante nos sistemas de produção agrícola.

\subsubsection{Análise dos mapas interpolados}

O banco de sementes do ano 2000 de Alternanthera tenella apresentou 4,3 ha da área total estudada (8,5 ha) com uma infestação de 0 a 20 sementes.m $^{-2}$, ou seja, 49,4\% da área total com uma baixa infestação de sementes, 0,8 ha $(9,4 \%)$ com uma densidade variando de 20 a 70 sementes.m $^{-2}$ e 3,4 ha com uma infestação variando de 70 a 5242 sementes.m $^{-2}$ (Figuras 13 a 15). A média geral do número de sementes foi de 178 sementes.m ${ }^{-2}$ em 2000. No banco de sementes de 2001 houve uma diminuição da infestação na maior classe de 70 a 1657 sementes.m ${ }^{-2}$, ocupando uma área menor de infestação (2,8 ha), a média geral este ano foi menor (68 sementes.m $\left.{ }^{-2}\right)$, demonstrando que o manejo entre safras realizado foi muito importante na redução do banco de sementes como um todo. Neste caso houve uma redução de $38 \%$ na infestação geral. 
Quando se analisou a variabilidade espacial dos mapas da Alternanthera tenella, o que pode ser observado é que áreas com altas infestações no banco de sementes do ano 2000 como as da parte superior do mapa, mantiveram a mesma tendência de variabilidade espacial no tempo. Obtendo se uma correlação visual mais evidente entre o banco de sementes coletado em 2000 com a flora emergida 2001 do que com o banco de sementes coletado no mesmo ano (2001), demonstrando que a variabilidade espacial do banco de sementes ao longo do tempo não mudou muito, já que a flora emergente se distribuiu espacialmente de forma semelhante. Esta correlação entre o banco de sementes 2000 com a flora 2001 foi o que obteve o maior coeficiente de correlação $(0,38)$ pelo teste de "Spearman rank" (Tabela 9).

A flora emergente de Alternanthera tenella na cultura de soja ficou restrita à porção superior, tendo 5,1 ha $(60 \%)$ da área sem a emergência da planta daninha, portanto, qualquer atitude de manejo e controle baseada na média de infestação desta planta daninha estaria superestimando a infestação em $60 \%$.

O banco de sementes do Panicum maximum foi diminuído em 26\% de um ano para outro com manejo mecânico e com herbicida não seletivo (glyphosate). Voll et al. (1997b) estudando diferentes formas de manejo do banco de sementes em outra gramínea (Digitaria horizontalis) obteve reduções maiores, em torno de 42 a 53\%. Analisando o mapa confeccionado (Figuras 16 a 18) não houve uma tendência de agregação clara do Panicum maximum na área estudada. Não houve correlação visual do banco de sementes entre as classes de infestações escolhidas. A flora emergente teve uma infestação em reboleiras, sendo que, 44\% da área estava isenta da gramínea, que foi uma das plantas mais problemáticas na área na cultura de milho que antecedeu a soja.

O Ageratum conyzoides emergido na soja no início de abril de 2001 teve uma correlação espacial visual alta quando comparado ao seu banco de sementes coletado em janeiro de 2001, e também teve uma correlação significativa $(0,32)$ pelo teste de "Spearman rank" feito anteriormente (Tabela 9). Quando seu banco de sementes coletado em 2001 foi comparado com o banco de sementes coletado em 2000, percebeu se que houve uma diminuição da densidade de sementes de 2000 para 2001 e que a estabilidade da distribuição espacial no tempo se mostrou evidente na parte inferior da 
área estudada (Figuras 19 a 21). Os respectivos bancos de sementes foram coerentes uns com os outros, pois várias regiões com altíssimas infestações de sementes (716-20680 sementes. $\mathrm{m}^{-2}$ ) no primeiro ano, se repetiram no ano consecutivo, demonstrando a estabilidade temporal da distribuição do banco de sementes. Deve-se ressaltar que a correlação visual do banco de sementes 2001 com a flora emergente em 2001 também foi muito boa, mostrando que a emergência de plântulas foi maior nas áreas de maior densidade de sementes.

A Commelina benghalensis não teve seu banco de sementes diminuído no mesmo grau que as outras plantas daninhas, este fenômeno pode ser devido à baixa eficácia do glyphosate na mesma e baixa eficiência do controle mecânico devido principalmente à altura de roçagem. A Commelina benghalensis foi a que mais se mostrou estável ao longo do tempo, comparando-se visualmente os mapas produzidos (Figuras 22 a 24), sendo sua correlação com o banco de sementes também significativa pelo teste de Spearman rank, com correlações significativas nas três comparações feitas (BS00/F01; BS00/F01 e BSS00/BS01), mostrando uma estabilidade espacial ao longo do tempo.

As floras das monocotiledôneas quase não emergiram na soja 2001 (Figuras 25 a 27), sendo representada somente pela Digitaria sanguinalis. Totalizando $90 \%$ da área com menos de uma planta.m $\mathrm{m}^{-2}$. O banco de sementes do ano 2000 já foi mais abundante e não apresentou nenhuma tendência de estabilidade temporal. A taxa de redução anual devido ao controle mecânico e químico com herbicida não seletivo foi de $48 \%$, semelhante ao resultado obtido por Voll et al. (1997b) em semeadura direta de soja.

Nas dicotiledôneas (Figuras 28 a 30) pode ser observado que também houve um comportamento contagioso, porém como foram muitas espécies de plantas daninhas que representaram esta classe, o comportamento e tendência de agregação das dicotiledôneas não demonstrou uma distribuição espacial estável ao longo do tempo na área.

Este comportamento mais estável do banco de sementes no tempo e a divisão em classes são muito importantes para a recomendação de misturas de herbicidas e para a possibilidade de criação de zonas de manejo diferenciadas. 


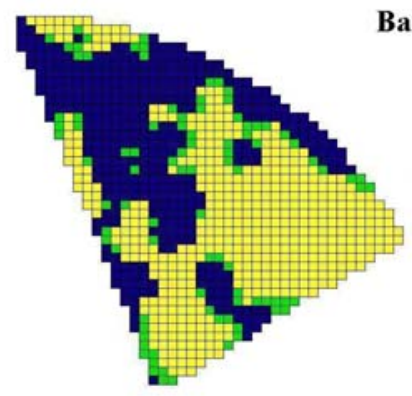

Banco de sementes 2000

Alternanthera tenella

$\begin{array}{ll}0-20 & (4,3 \mathrm{ha}) \\ 20-70 & (0,8 \mathrm{ha})\end{array}$

70 - $5242(3,4$ ha)

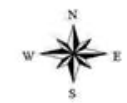

Figura 13 - Mapa interpolado por "krigagem" do banco de sementes coletado em junho de 2000 de Alternanthera tenella representado em células de $10 \times 10 \mathrm{~m}$, dividido em três classes de infestações de sementes.m ${ }^{-2}$.

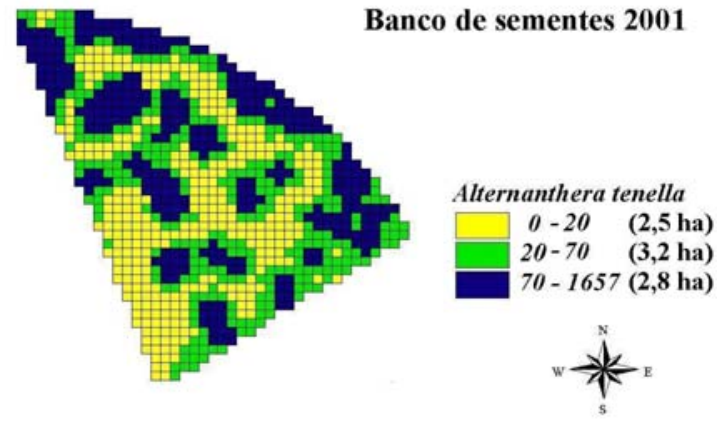

Figura 14 - Mapa interpolado por krigagem do banco de sementes coletado em janeiro de 2001 de Alternanthera tenella representado em células de $10 \times 10 \mathrm{~m}$, dividido em três classes de infestações de sementes. $\mathrm{m}^{-2}$.

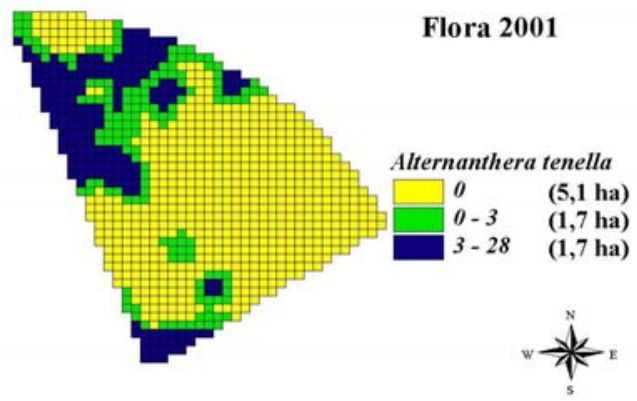

Figura 15 - Mapa interpolado por "krigagem" da flora emergente em abril de 2001 de Alternanthera tenella representado em células de $10 \times 10 \mathrm{~m}$, dividido em três classes de infestações de plantas. $\mathrm{m}^{-2}$. 


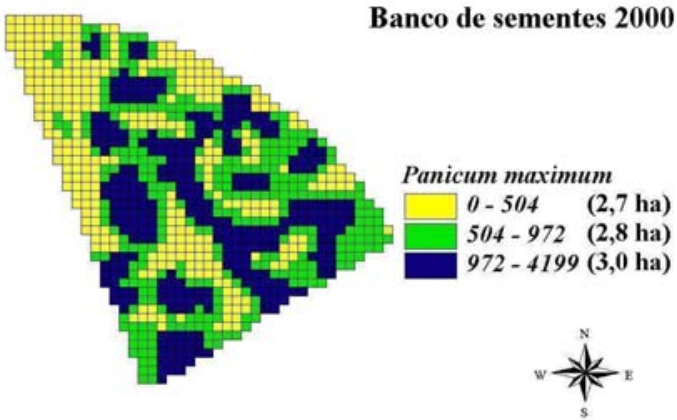

Figura 16 - Mapa interpolado por "krigagem" do banco de sementes coletado em junho de 2000 de Panicum maximum representado em células de $10 \times 10 \mathrm{~m}$, dividido em três classes de infestações de sementes.m ${ }^{-2}$.

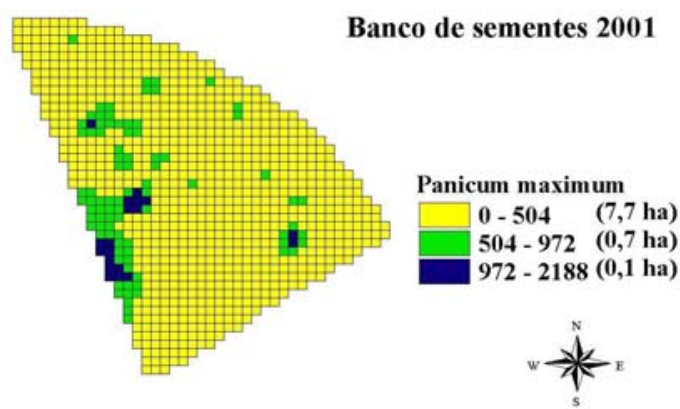

Figura 17 - Mapa interpolado por "krigagem" do banco de sementes coletado em janeiro de 2001 de Panicum maximum representado em células de $10 \times 10 \mathrm{~m}$, dividido em três classes de infestações de sementes. $\mathrm{m}^{-2}$

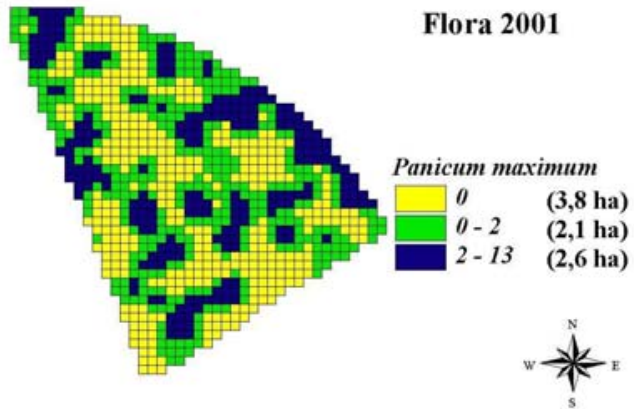

Figura 18 - Mapa interpolado por "krigagem" da flora emergente em abril de 2001 de Panicum maximum representado em células de 10 × 10 m, dividido em três classes de infestações de plantas. $\mathrm{m}^{-2}$. 


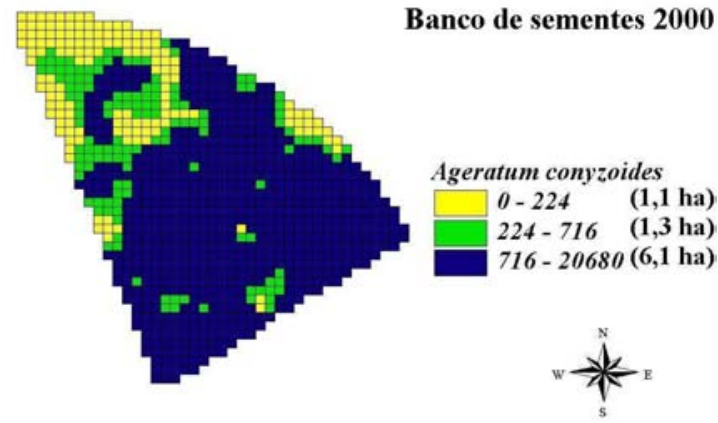

Figura 19 - Mapa interpolado por "krigagem" do banco de sementes coletado em junho de 2000 de Ageratum conyzoides representado em células de $10 \times 10 \mathrm{~m}$, dividido em três classes de infestações de sementes. $\mathrm{m}^{-2}$.

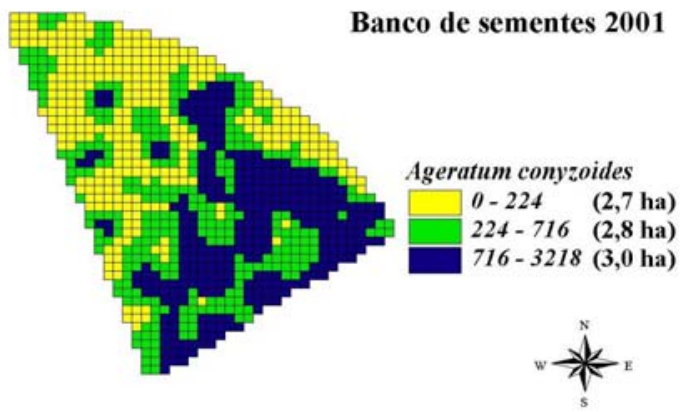

Figura 20 - Mapa interpolado por "krigagem" do banco de sementes coletado em janeiro de 2001 de Ageratum conyzoides representado em células de $10 \times 10 \mathrm{~m}$, dividido em três classes de infestações de sementes. $\mathrm{m}^{-2}$.

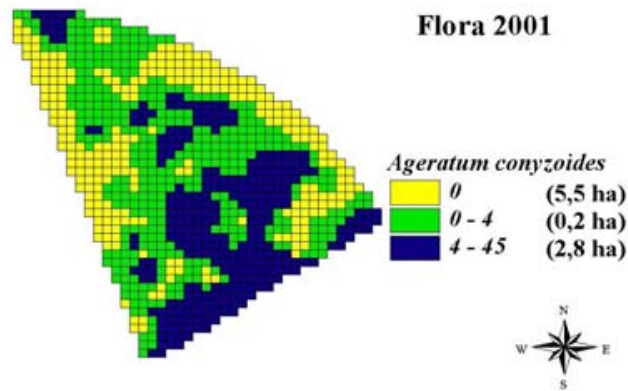

Figura 21 - Mapa interpolado por "krigagem" da flora emergente em abril de 2001 de Ageratum conyzoides representado em células de $10 \times 10$ m, dividido em três classes de infestações de plantas. $m^{-2}$. 


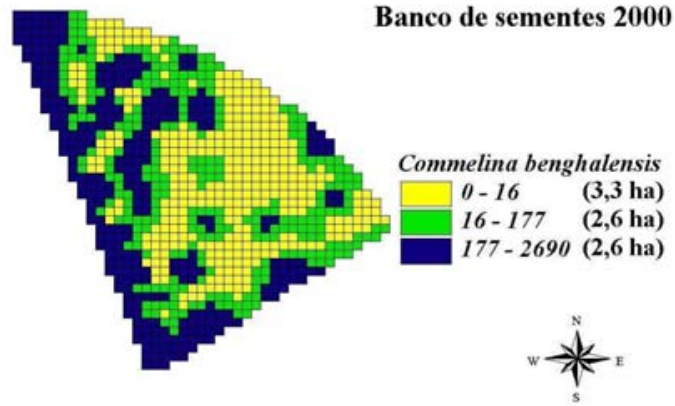

Figura 22 - Mapa interpolado por "krigagem" do banco de sementes coletado em junho de 2000 Commelina benghalensis representado em células de $10 \times 10 \mathrm{~m}$, dividido em três classes de infestações de sementes.m ${ }^{-2}$.

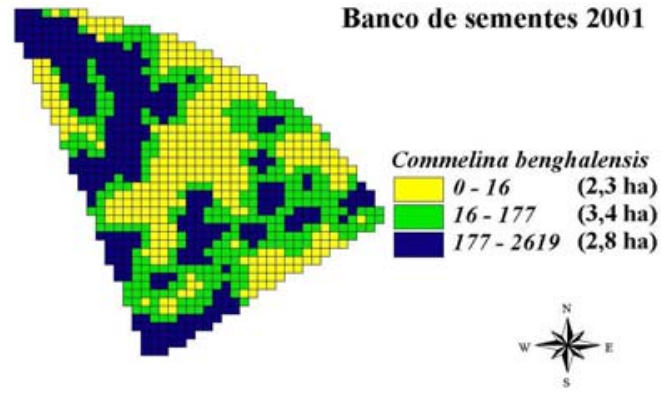

Figura 23 - Mapa interpolado por "krigagem" do banco de sementes coletado em janeiro de 2001 de Commelina benghalensis representado em células de $10 \times 10 \mathrm{~m}$, dividido em três classes de infestações de sementes. $\mathrm{m}^{-2}$.

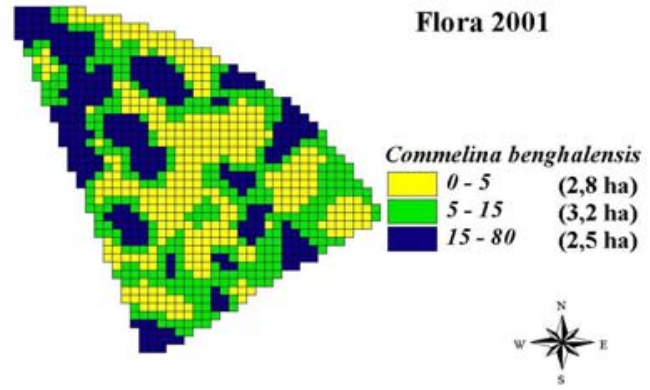

Figura 24 - Mapa interpolado por "krigagem" da flora emergente em abril de 2001 de Commelina benghalensis representado em células de $10 \times 10$ m, dividido em três classes de infestações de plantas. $\mathrm{m}^{-2}$. 


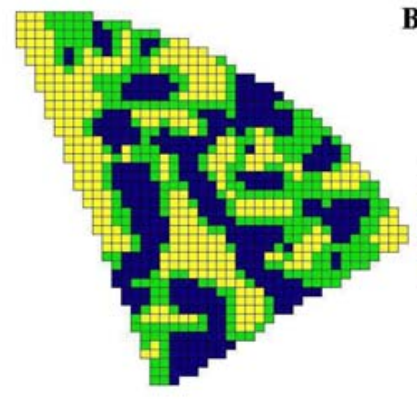

Banco de sementes 2000

Monocotiledôneas

0 - $600 \quad$ (2,8 ha)

1087 - 4261 ( 3,0 ha)

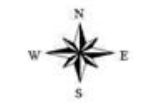

Figura 25 - Mapa interpolado por "krigagem" do banco de sementes coletado em junho de 2000 de plantas monocotiledôneas representado em células de 10 × 10 m, dividido em três classes de infestações de sementes. $\mathrm{m}^{-2}$.

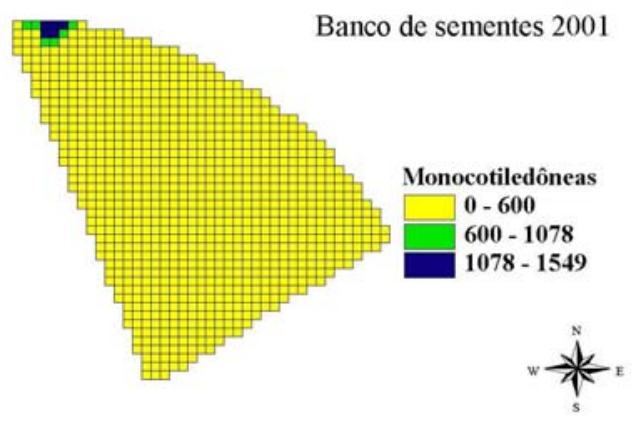

Figura 26 - Mapa interpolado por "krigagem" do banco de sementes coletado em janeiro de 2001 de plantas monocotiledôneas representado em células de $10 \times 10 \mathrm{~m}$, dividido em três classes de infestações de sementes.m ${ }^{-2}$

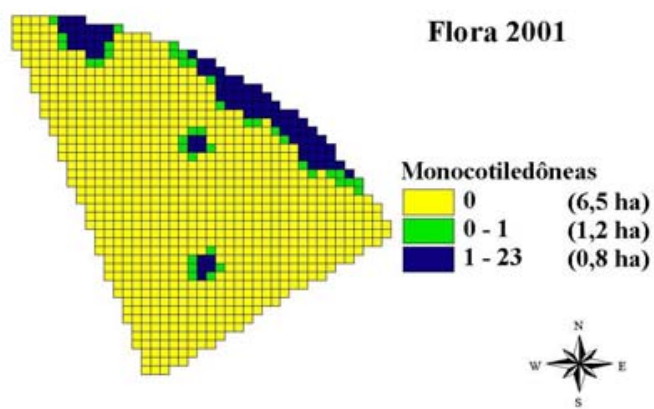

Figura 27 - Mapa interpolado por "krigagem" da flora emergente em abril de 2001 de plantas monocotiledôneas representado em células de $10 \times 10$ m, dividido em três classes de infestações de plantas. $\mathrm{m}^{-2}$. 


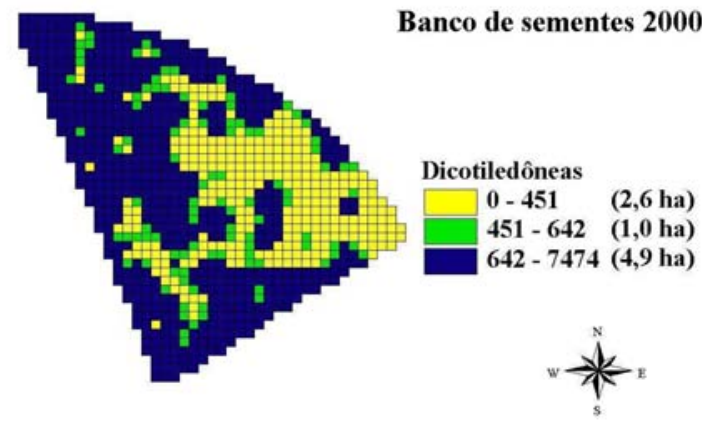

Figura 28 - Mapa interpolado por "krigagem" do banco de sementes coletado em junho de 2000 de plantas dicotiledôneas representado em células de 10 x 10 m, dividido em três classes de infestações de sementes. $\mathrm{m}^{-2}$.

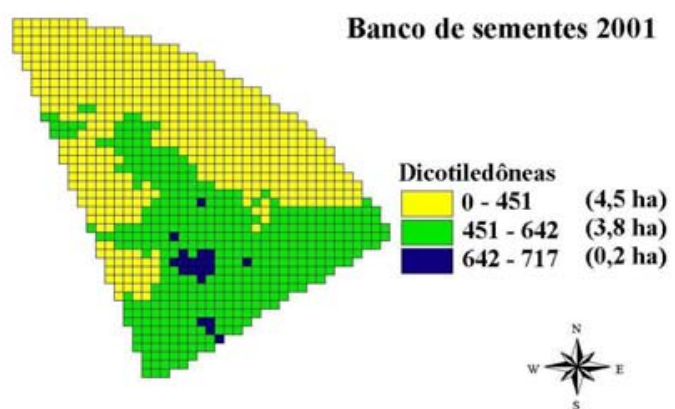

Figura 29 - Mapa interpolado por "krigagem" do banco de sementes coletado em janeiro de 2001 de plantas dicotiledôneas representado em células de $10 \times 10 \mathrm{~m}$, dividido em três classes de infestações de sementes. $\mathrm{m}^{-2}$.

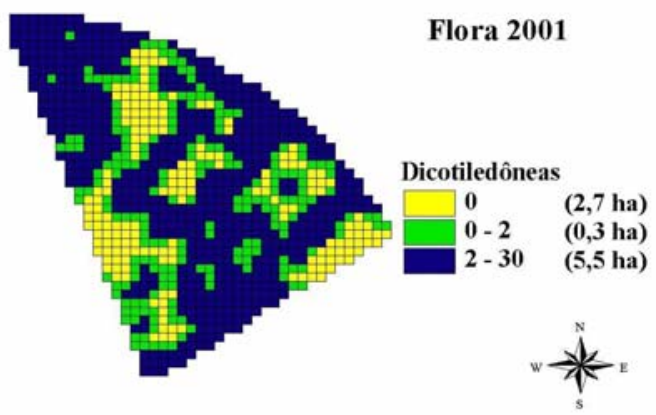

Figura 30 - Mapa interpolado por "krigagem" da flora emergente em abril de 2001 de plantas dicotiledôneas representado em células de 10 x 10 m, dividido em três classes de infestações de plantas. $m^{-2}$. 


\subsection{Conclusões}

A flora emergente das plantas daninhas Alternanthera tenella, Panicum maximum, Ageratum conyzoides e Commelina benghalensis apresentaram uma tendência de agregação em regiões na cultura da soja, tendo um alcance ou "range" variando de 7 a $15 \mathrm{~m}$ para a flora emergente e de 7 a $14 \mathrm{~m}$ para o banco de sementes. Portanto amostragens feitas para a flora emergente e o banco de sementes a distâncias maiores que $15 \mathrm{~m}$ para estas plantas não serão dependentes espacialmente uma das outras.

Dentre as plantas daninhas estudadas, Ageratum conyzoides e Commelina benghalensis, principalmente, apresentaram uma estabilidade temporal significativa nestes dois anos de estudo, principalmente quando se comparou a flora emergente com os bancos de sementes avaliados nos dois anos consecutivos pelo teste de "Spearman rank". Este fenômeno foi confirmado visualmente com a análise dos mapas de infestações gerados principalmente quando se compara a flora emergente com o banco de sementes coletado no mesmo ano.

A correlação entre bancos de sementes de dois anos consecutivos também foi significativa para estas duas plantas, demonstrando que existe um certo grau de estabilidade temporal do banco de sementes dentro da área agrícola estudada sob plantio direto. Este fenômeno possibilita o planejamento estratégico de se delinear áreas onde se prevê uma maior infestação das plantas daninhas. 


\section{MAPEAMENTO DA DISTRIBUIÇÃO ESPACIAL DA INFESTAÇÃO DO CAPIM COLONIÃO (Panicum maximum Jacq.) DURANTE A COLHEITA DA CULTURA DE MILHO.}

\section{Resumo}

Diversas metodologias de mapeamento de plantas daninhas estão sendo usadas para que a confecção de mapas de tratamento localizado de herbicidas seja possível utilizando equipamentos da agricultura de precisão. Estes mapas são responsáveis pelo comando de pulverizadores capazes de realizar a aplicação localizada de herbicidas, aproveitando o comportamento contagioso inerente da comunidade das plantas daninhas. Porém poucos experimentos relatam a eficiência de tais métodos. Este experimento tem o objetivo de aferir a metodologia de mapeamento do capim colonião (Panicum maximum Jacq.) durante a colheita de milho realizada com um equipamento sem correção diferencial ("Garmin 12") com a metodologia de amostragem em grade após a colheita utilizando um DGPS de mochila ("Omnistar"). O mapeamento consistiu de marcações feitas durante a colheita sendo aferida após a colheita por amostragens numa grade regular de $20 \times 20$ m. Foi observada uma subestimação de $6 \%$ da área infestada com uma infestação de mais de $80 \%$ de cobertura pelo método de mapeamento durante a colheita quando comparado com o caminhamento na grade regular após a colheita. Os dois métodos foram coincidentes em $45 \%$ da área marcada. Portanto, quando se adotou a grade de 20 x 20 m como referência da alta infestação do capim colonião o método de marcação na colheita obteve uma eficiência de $45 \%$. 


\section{MAPPING THE SPATIAL DISTRIBUTION OF Panicum maximum Jacq. DURING CORN (Zea mays L.) HARVESTING}

\section{Summary}

Many methods of weed infestation mapping have been tested for scouting weeds in the agricultural fields using precision farming tools regarding the clumping of the weed community. And then these maps are being used to create herbicide treatment maps becoming possible to spray herbicides only where they are needed. But, a few experiments have shown the method efficiency. This research had the aim to evaluate the method of mapping Panicum maximum Jacq during corn harvest from a combine harvester comparing to the maps created with the grid sampling method. The weed mapping from a combine harvester was done using a pocket GPS without differential correction (“Garmin 12”) and for grid sampling method a backpack DGPS (“Omnistar”) was used. It was observed that the harvest method recorded about $6 \%$ less than the grid sampling and about $45 \%$ of the weed recorded infestation was overlaid, showing that in this experiment mapping Panicum maximum from a combine harvester had about $45 \%$ of efficiency comparing with grid sampling method used.

\subsection{Introdução}

A infestação das plantas daninhas normalmente não ocorre de forma uniforme nas áreas de produção agrícolas, sendo possível o mapeamento de sua variabilidade espacial com a utilização de ferramentas da agricultura de precisão. Dessa forma são possíveis aplicações de herbicidas de forma mais racional quando comparada com pulverizações que se baseiam na média das infestações sem levar em consideração o grau de distribuição das plantas daninhas nas áreas.

Vários métodos de mapeamento das plantas daninhas foram testados até então em outros países, sendo os mais conhecidos os seguintes: (i) amostragens sistemáticas em grade: consiste na divisão da área em uma grade amostral, sendo amostrados as 
densidades das plantas daninhas para cada célula. Embora seja o mais estudado e preciso se utilizado em grades adequadas, sua aplicação restringe se a áreas pequenas e experimentais devido à dificuldade operacional (Lutman \& Perry, 1999), (ii) método de contorno das áreas de ocorrência: é feito contornando as "reboleiras" das diferentes plantas daninhas dentro da área agrícola gerando polígonos de infestações (Lass \& Callihan, 1993; Colliver et al., 1996), (iii) método linear: marcações de regiões de infestações durante o trafego de máquinas ou outro tipo de operação dentro a área agrícola (Rew et al, 1996 e Kvien et al, 1997) e (iv) sensoriamento remoto feito por avião, satélites e sensores acoplados aos pulverizadores, porém este método apresenta como problema as limitações de resolução dos equipamentos e custo (Lutman \& Perry, 1999). Todos os métodos estão sendo avaliados e ainda não existe um método de mapeamento definido para grandes extensões agrícolas (Christensen et al., 1999c).

Dentre as diversas metodologias testadas para a realização do mapeamento das plantas daninha. A metodologia de mapeamento durante a colheita da cultura é atualmente a mais utilizada em áreas agrícolas dos Estados Unidos da América do Norte pela sua facilidade metodológica de mapeamento, pois ela aproveita a operação de colheita para realização do mapeamento, sendo possível obter mapas pós-colheita que poderão servir de base para a próxima safra (Lutman \& Perry, 1999). Trabalhos de pesquisa com plantas daninhas anuais evidenciam que a disseminação de sementes e plantas pela colhedora é um dos principais fatores que influem na localização de futuras “reboleiras", que são matematicamente previsíveis (Colliver et al. 1996).

O mapeamento da infestação da flora daninha durante a colheita da cultura consiste na marcação georeferenciada das "reboleiras" das plantas daninhas na operação de colheita. Durante o caminhamento da colhedora equipada com DGPS, o operador faz marcações quando o mesmo entra em alguma "reboleira" de planta daninha, sabendo-se a largura da plataforma de colheita e a posição em que o operador começa a marcação e a posição onde termina a marcação é determinada a faixa onde foi considerada a presença de determinada planta daninha (Colliver et al., 1996).

O objetivo deste experimento foi realizar o mapeamento do capim colonião (Panicum maximum L.) durante a operação de colheita do milho e aferi-lo com o método 
de amostragens sistemáticas para a criação de mapas de prescrição de herbicidas de manejo.

\subsection{Material e Métodos}

A área experimental onde o experimento foi conduzido era de 8,5 ha e encontravase sob irrigação por aspersão tipo pivô central que irrigava uma área total de 70 ha, sendo adotado o sistema de plantio direto na cultura do milho desde 1998. Os tipos de solo predominantes foram: terra roxa estruturada e latossolo roxo eutrófico.

Foram realizados mapeamentos durante e após a colheita de milho 2000/2001, colhido na segunda quinzena de janeiro de 2001. O mapeamento após a colheita foi realizado no intuito de aferir o mapeamento feito durante a colheita do milho.

Na colheita foi utilizada uma colhedora “John Deere/9650”, equipada com DGPS, sendo o posicionamento da mesma utilizado para o georeferenciamento das marcações ou "flags" das reboleiras do capim colonião. O mapeamento durante a operação de colheita foi feito pelo operador seguindo a escala visual, sendo que o operador marcava as áreas com mais de $80 \%$ de cobertura do terreno com a planta daninha, segundo escala

proposta por Harvey \& Wagner (1992). As marcações eram iniciadas quando a plataforma de colheita atingia a "reboleira" (Figura 31) de alta infestação de capim colonião e terminava na saída da colhedora da "reboleira", obtendo-se diversas faixas de alta infestação da planta daninha mapeada. Simultaneamente, foram feitas marcações por outra pessoa previamente treinada na identificação e atribuição de notas de infestações segundo a escala adotada, utilizando um equipamento GPS portátil sem correção diferencial, no intuito de aferir o mapa de infestação gerado pelo operador. Foi considerada uma margem de segurança de posicionamento da infestação de 7,5 m lado a lado da colhedora com plataforma ajustada a $4,8 \mathrm{~m}$, totalizando $20 \mathrm{~m}$ de largura de faixa infestada. 


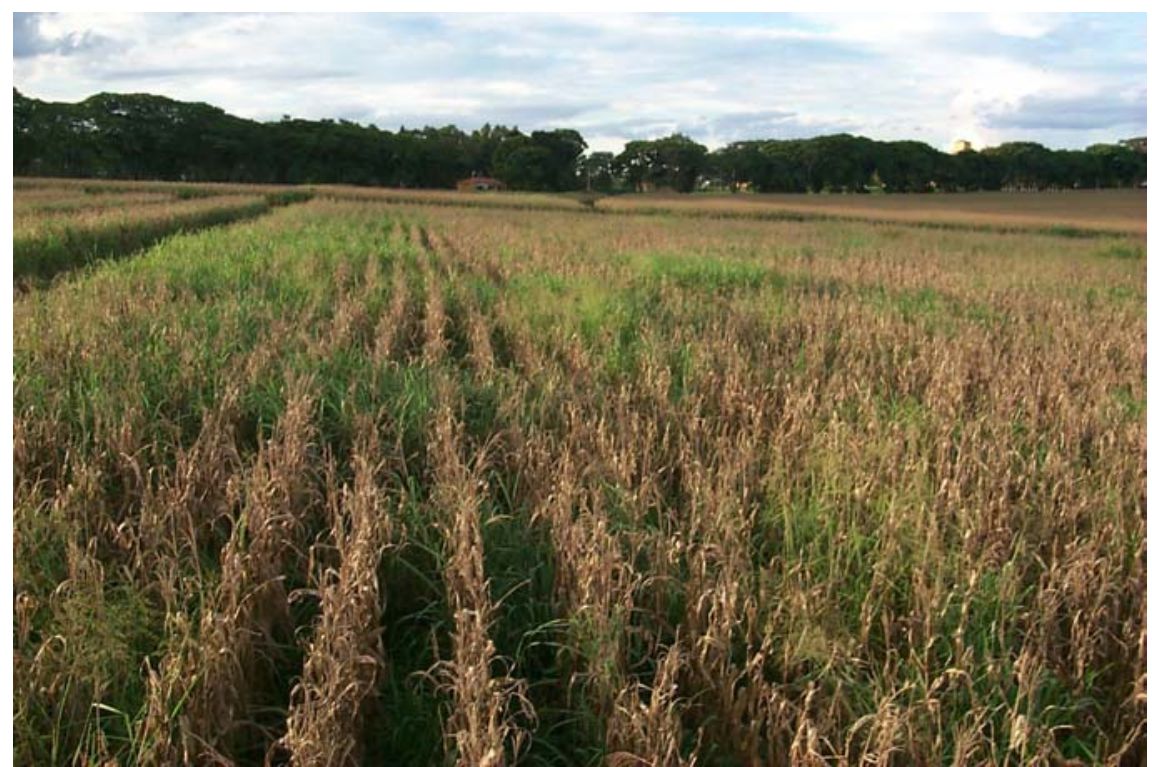

Figura 31 - Vista das reboleiras de alta infestação de capim colonião no momento da colheita

Os dados das marcações feitas pelo operador da colhedora foram separados dos demais dados originários do arquivo gerado pelo sistema, tais como, dados de umidade dos grãos, produtividade e tempo, sendo previamente organizados no programa "Excel" e em seguida, processados no software "SSToolbox/SST". Adotou-se um número arbitrário para os pontos onde foram marcadas as infestações altas de capim colonião, sendo transformados em vários pontos com um mesmo valor no intuito de se obter uma seqüência de pontos formando as faixas de infestações. Para a transformação dos pontos em faixas de $20 \mathrm{~m}$ foi considerado $5 \mathrm{~m}$ da plataforma e 7,5 $\mathrm{m}$ de faixa de segurança de cada lado da colhedora com o objetivo de facilitar a comparação com o método sistemático de amostragem em grade feito pelo caminhamento pós-colheita que utilizou uma grade de $20 \times 20 \mathrm{~m}$.

O mapeamento pelo método de amostragens sistemáticas após a colheita feito como aferição do método de mapeamento durante a colheita, consistiu de um caminhamento simulando o percurso da colhedora com um equipamento DGPS de mochila registrando os dados de infestações numa grade de 20 x $20 \mathrm{~m}$ feito imediatamente antes da pulverização do herbicida de manejo, ou seja, uma semana após 
a colheita. A distribuição foi georeferenciada por um receptor de GPS com correção diferencial via satélite acoplado a um computador portátil. Foram marcados somente os pontos georeferenciados com alta infestação do capim colonião, segundo a mesma escala visual de cobertura do terreno adotado pelo método da colhedora. $\mathrm{O}$ caminhamento foi realizado uma semana após a colheita do milho em janeiro de 2001, quando os danos causados ao capim colonião durante a operação de colheita já haviam sido recuperados.

\subsection{Resultados e Discussão}

Analisando os dados das marcações feitas durante a colheita pelo operador ficou constatada uma superestimação das áreas de alta infestação do capim colonião, pois eventualmente o operador da colhedora esquecia de desligar a marcação mesmo que a plataforma saia da "reboleira" e isto se devia à complexidade dos diversos equipamentos manuseados pelo operador ao mesmo tempo, deixando erros representando faixas contínuas de alta infestação de capim colonião. Portanto, as marcações feitas pelo operador foram desconsideradas no momento da avaliação do mapa feito durante a colheita, não podendo desta maneira fazer comparações das marcações feitas pelo equipamento sem diferencial com as marcações com correção diferencial feitas pelo operador. Porém, as marcações feitas pela pessoa que acompanhou o operador da colhedora com o equipamento sem diferencial foram suficientes para a geração do mapa de aplicação de herbicida de manejo.

A porcentagem de cobertura da área com alta infestação do capim colonião utilizando o equipamento portátil sem diferencial foi de $26 \%$ e o caminhamento após a colheita verificou $32 \%$ da área total. Ou seja, o mapeamento durante a colheita subestimou em 6\% a área com alta infestação (Tabela 10). 
Tabela 10. Área de infestação considerada alta ( $80 \%$ de cobertura) de capim colonião (Panicum maximum) e o tempo utilizado para levantamento da área após a colheita do milho.

\begin{tabular}{ccccc}
\hline Metodologia & $\begin{array}{c}\text { Área total } \\
(\text { ha })\end{array}$ & $\begin{array}{c}\text { Área - alta infestação } \\
(\text { ha })\end{array}$ & $\begin{array}{c}\text { Infestação } \\
(\%)\end{array}$ & $\begin{array}{c}\text { Tempo gasto } \\
\text { (horas) }\end{array}$ \\
\hline Grade $20 \times 20$ & 8,5 & 2,76 & 32 & 4 \\
Colheita & 8,5 & 2,24 & 26 & ND \\
\hline
\end{tabular}

Dos 56 pontos marcados na colheita 31 foram coincidentes com o total de 69 marcações feitas e consideradas de alta infestação do capim colonião pelo método de amostragens sistemáticas, resultando em $45 \%$ de áreas coincidentes entre os dois métodos. Como o levantamento por amostragens sistemáticas na grade de 20 x $20 \mathrm{~m}$, que foi adotada como referência, verifica-se que o método de mapeamento durante a colheita obteve $45 \%$ de eficiência.

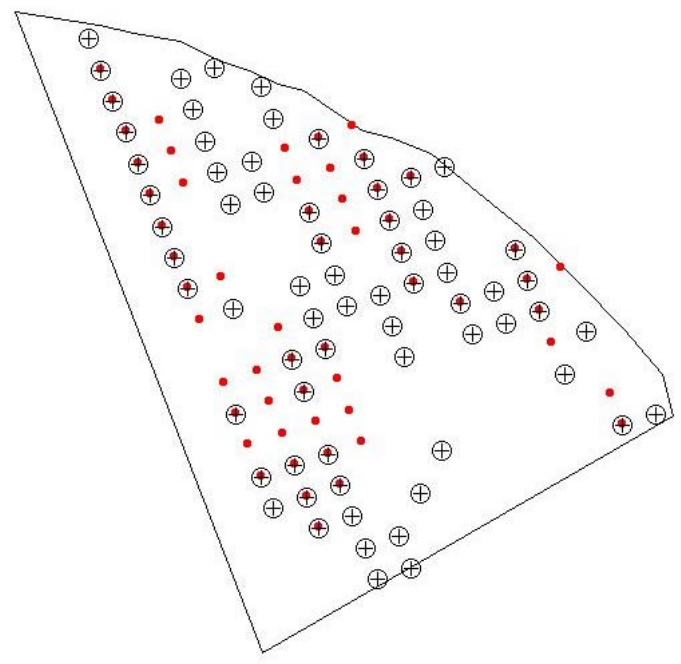

Amostragens sistemáticas para aferição $\oplus \quad$ Alta infestação Marcações durante a colheita

- Alta infestação $\square$ Área experimental

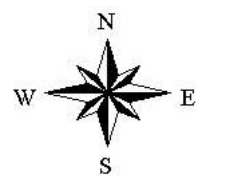

Figura 32 - Mapa das marcações de alta infestação de capim colonião feitas durante e após a colheita do milho 
Experimento semelhante foi realizado por Colliver et al (1996) mapeando a cobertura do terreno pela planta daninha Avena fatua em função da presença da mesma durante a colheita, fazendo comparações com o método de amostragens sistemáticas numa grade de $5 \times 10 \mathrm{~m}$ e com o método de contorno das áreas de ocorrência. Numa área foram determinadas infestações em $61 \%$ da área em marcações feitas durante a colheita e $42 \%$ pelo método de amostragens sistemáticas e $43 \%$ pelo método de contorno das "reboleiras" com uma correlação de 27\% dos três métodos. Em outra área obtiveram $90 \%$ de cobertura na colheita, $69 \%$ em amostragens sistemáticas e $67 \%$ pelo contorno, com uma área comum aos três métodos de $56 \%$.

$\mathrm{Na}$ área experimental onde foi conduzida a presente pesquisa foi feita uma tentativa de realização do mapeamento pelo contorno das áreas de ocorrência, porém como a área possuía infestação severa do capim colonião, não foi possível a distinção das "reboleiras". Da mesma forma Stafford et al. (1996) citaram como resultado deste tipo de mapeamento, que a dificuldade de se contornar uma "reboleira" depende do nível de infestação, do grau de contagiosidade e do tipo de planta estudada, além de ser muito difícil a distinção dos limites entre elas.

A amostragem sistemática na grade de $20 \times 20 \mathrm{~m}$ determinou 24 pontos adicionais de alta infestação não marcados durante a colheita, ou seja, aproximadamente um hectare a mais foi considerado com alta infestação durante o caminhamento e que não foram marcados durante a colheita. Da mesma forma foram marcados 23 pontos considerados de alta infestação durante a colheita que não foram considerados de alta infestação pelo método de amostragens. A amostragem sistemática da área experimental de 8,5 ha demorou cerca de 4 horas, visto que se buscava uma grande adequação à escala visual utilizada como referência. (Tabela 10).

A aplicação localizada de herbicida de manejo não foi realizada, porém algumas considerações importantes podem ser feitas baseadas no mapa de distribuição do capim colonião resultantes do mapeamento na colheita: (i) como somente $32 \%$ da área foi considerada com alta infestação, se fosse realizada uma pulverização herbicida na forma convencional em área total tomando por base as regiões de alta infestação, nos $68 \%$ restantes da área com infestações menores teria sido utilizada dosagem desnecessária de 
herbicida, por outro lado se o referencial fosse a área de menor infestação, os $32 \%$ de alta infestação poderiam não ser suficientemente controlados com o herbicida de manejo, (ii) o mapeamento segundo níveis de infestações pode ser adotado devido a sua praticidade e rapidez, (iii) economias consideráveis de herbicidas podem ser atingidas não somente pelo motivo de não utilização, mas também pela melhor alocação das doses dentro do sistema de produção agrícola (Lindquist et al., 1998; Medlin \& Shaw, 2000).

As principais dificuldades encontradas no mapeamento durante a colheita foram: (i) alta infestação da área experimental com o capim colonião impossibilitando o mapeamento por contorno das áreas de ocorrência, inviabilizando a avaliação e utilização do método (ii) subestimação da infestação das plantas daninhas devido à sobreposição pela cultura, (iii) relativo atraso na colheita possibilitando um reinfestação tardia do capim colonião na área.

\subsection{Conclusões}

A metodologia avaliada de mapeamento durante a operação de colheita não foi capaz de identificar alguns pontos de alta infestação detectados pela amostragem sistemática na grade de 20 x 20 m utilizada como aferição do método de marcações ("flags") durante a colheita. Portanto, foram subestimados alguns pontos considerados de alta infestação. O mapeamento durante a colheita obteve uma correlação de 45\% quando comparado ao padrão adotado para a aferição, que foi a amostragem sistemática em grade de $20 \times 20 \mathrm{~m}$.

Apesar dos problemas observados no mapeamento da infestação durante a colheita, esta metodologia tem grande potencial de uso na agricultura e pode servir de base na elaboração de mapas de aplicação localizada de herbicidas de manejo ou de previsão de futuras infestações de plantas daninhas. 


\section{APLICAÇÃO LOCALIZADA DE HERBICIDAS EM PÓS-EMERGÊNCIA NA CULTURA DE SOJA}

\section{Resumo}

Com o crescimento do interesse pela aplicação localizada de herbicidas, considerando a variabilidade espacial da comunidade das plantas daninhas, torna-se necessário o conhecimento da eficácia destas aplicações herbicidas comparada com a aplicações convencionais em área total. Um experimento foi desenvolvido com o objetivo de avaliar a eficácia de controle das plantas daninhas através da aplicação localizada de herbicidas em comparação com a aplicação em área total. Foram escolhidas quatro áreas de 0,5 há, sendo que em duas delas foi feito o mapeamento da densidade de infestação das plantas daninhas, antes e após a aplicação herbicida, utilizando o método de amostragens numa grade regular de $6 \times 6 \mathrm{~m}$ utilizando áreas amostrais de $0,25 \mathrm{~m}^{2}$, sendo duas áreas utilizadas para a pulverização convencional $\mathrm{e}$ duas áreas com mapeamento das plantas daninhas para a pulverização localizada. As avaliações das infestações das plantas daninhas foram feitas antes e após a aplicação localizada de herbicidas, nos mesmos locais nas duas avaliações. Aplicou-se duas dosagens da mistura formulada dos herbicidas fluazifop butyl $\left(125 \mathrm{~g} \cdot \mathrm{L}^{-1}\right)+$ fomesafen (250g.L $\mathrm{L}^{-1}$ ), sendo a dose de $1 \mathrm{~L} \cdot \mathrm{ha}^{-1}$ da mistura formulada para densidades de plantas daninhas abaixo de 50 plantas. $\mathrm{m}^{-2}$ e dose de 2 L.ha $^{-1}$ para densidades acima de 50 plantas. $\mathrm{m}^{-2}$. A comparação da aplicação convencional a 2 L.ha ${ }^{-1}$ com a aplicação localizada mostrou economias de herbicidas da ordem de $18 \%$ e $44 \%$ para as duas áreas estudadas respectivamente. Foi detectado $55 \%$ e $77 \%$ das áreas livres de infestação, sendo verificado nestas áreas densidades muito baixas. Portanto a aplicação localizada de herbicida realizada neste experimento mostrou que grandes economias de produtos são possíveis mantendo a eficácia de controle e conseqüentemente reduzindo o impacto ambiental da aplicação herbicida em área total. 


\section{SITE SPECIFIC WEED MANAGEMENT IN SOYBEAN SPRAYING POST EMERGENCE HERBICIDES}

\section{Summary}

Current interest in site-specific weed control regarding the weed spatial variability is increasing nowadays, when economical and environmental aspects are considered. But, a few studies of the efficacy of the chemical control have been conducted until now. Therefore, a field experiment was developed with the objective of evaluating the chemical control of weeds applying the site-specific weed control method compared to conventional broadcast application. Four fields of 0.5 ha were chosen and in two of them weeds were surveyed using the systematic grid sampling in a regular grid of $6 \times 6 \mathrm{~m}$ and counting weeds inside a $0.25 . \mathrm{m}^{2}$ quadrat. Two fields where weeds were mapped were used for site-specific application and two fields for conventional broadcast application. The quadrat counts was done before and after the chemical control in the same location near the stacks. It was used two label rates of the herbicide tank mixture of fluazifop butyl (125g.L $\left.\mathrm{L}^{-1}\right)$ plus fomesafen $\left(250 \mathrm{~g} . \mathrm{L}^{-1}\right)$, applying $1 \mathrm{~L} . \mathrm{ha}^{-1}$ of the herbicide mixture at

sites under 50 weed seedlings. $\mathrm{m}^{-2}$ and $2 \mathrm{~L} . \mathrm{ha}^{-1}$ of the same tank mixture at sites above 50 seedlings. $\mathrm{m}^{-2}$. Compared to broadcast application, site specific application saved $18 \%$ in one field and $44 \%$ in the other. Both of them had satisfactory chemical control with 55\% and $77 \%$ of the fields weed free, at very low densities. So, this research showed that high herbicides savings are possible, maintaining the efficacy of chemical control using the site-specific herbicide weed management, and consequently reducing the environmental impact of the broadcast application of herbicides.

\subsection{Introdução}

Dentro do contexto agrícola o controle das plantas daninhas através de herbicidas é um dos métodos mais utilizados e sua correta utilização quase sempre aumenta a produtividade das culturas pela minimização da interferência das plantas daninhas. 
Porém, a utilização incorreta de técnicas e equipamentos pode comprometer o controle eficaz e conseqüentemente pode diminuir a renda do agricultor, já que os herbicidas podem participar com até $30 \%$ do custo total de produção da soja (FNP Consultoria \& Comércio, 2000).

Com a utilização de técnicas da agricultura de precisão, que segundo Molin (1997) preconiza o tratamento e gerenciamento de sistemas de produção com a utilização de ferramentas como o GPS, softwares de SIG, sensores e máquinas avançadas com controle de aplicação a taxas variáveis, o controle das plantas daninhas passa por uma crescente evolução no que concerne a aplicação considerando a variabilidade espacial das plantas daninhas nas áreas agrícolas.

Experimentos já realizados (Green \&Vencill, 1997; Engqvist et al., 1997; Heisel et al., 1997) demonstraram que a aplicação localizada de herbicidas é mais econômica que a aplicação convencional de herbicidas em área total, a qual é baseada na infestação média de plantas daninhas na área agrícola. O comportamento contagioso das plantas daninhas é mais regra que exceção. Porém muitos destes trabalhos não relatam a eficiência de controle após a aplicação, restringindo-se a analisar a economia de herbicidas.

Para a adoção de técnicas de aplicação localizada de herbicidas é necessário o entendimento e a avaliação da eficácia de controle das plantas daninhas ao se utilizar a técnica. Poucos trabalhos foram feitos neste sentido no mundo, sendo relevante os trabalhos de Williams II et al. (1999ab).

Sendo assim, um experimento foi instalado com o objetivo de avaliar a eficácia do controle das plantas daninhas através da aplicação localizada de herbicidas considerando a variabilidade espacial das plantas daninhas no período crítico de competição com a soja.

\subsection{Material e Métodos}

A área experimental pertencente à Universidade de São Paulo está localizada em Pirassununga - SP, na Faculdade de Zootecnia e Engenharia de Alimentos (USP/FZEA), 
sendo cultivada com a utilização do sistema de plantio direto desde 1998. O experimento foi realizado sob um quadrante de 8,5 ha de uma área irrigada sob pivô central de 78 ha em solo classificado como latossolo roxo eutrófico e terra roxa estruturada eutrófica. A cultivar de soja utilizada foi a Conquista plantada na primeira quinzena de março de 2001 após a colheita do milho utilizando uma população de plantas de 300000 plantas.ha ${ }^{-1}$, com um espaçamento de $0,45 \mathrm{~m}$ entre fileiras. Foi utilizado o herbicida de manejo glyphosate para a dessecação pré-plantio.

Dentro da área agrícola foram escolhidas quatro sub áreas de aproximadamente 0,5 ha cada, agrupadas duas a duas foram alocadas aleatoriamente dentro da cultura da soja. Ficando duas áreas vizinhas, a área (Área A) para a aplicação localizada e ao lado outra área como testemunha (Área TA), onde foi feita a aplicação convencional uniforme. Da mesma forma foi alocada outras duas áreas (Área B e Área TB). A avaliação da densidade de infestação das plantas daninhas foi feita somente nas áreas onde foi feita a pulverização localizada de herbicida (Áreas A e B), sendo adotado a escala de eficácia e seletividade do controle proposta pela Sociedade Brasileira da Ciência das Plantas Daninhas (1995).

O mapeamento foi realizado quando a soja estava no estádio V4 - V5, segundo escala de Fehr \& Caviness (1977), quando as plantas daninhas estavam na fase inicial de desenvolvimento. Para o georeferenciamento as duas subáreas foram estaqueadas numa grade de 6 × $6 \mathrm{~m}$. O processamento dos dados e a geração dos mapas de distribuição das plantas daninhas foram feitos no software "SSToolbox / SST". As plantas daninhas foram mapeadas pela metodologia de amostragens sistemáticas, que consistiu no caminhamento em uma grade de 6 x $6 \mathrm{~m}$ estaqueada anteriormente à avaliação.

As avaliações da densidade de plântulas ("seedlings") foram feitas posicionandose o quadrado amostral de $0,25 \mathrm{~m}^{2}$ duas vezes ao lado da estaca, uma na fileira da cultura e outra entre as fileiras. A amostra foi composta da média destas duas sub amostras, sendo, portanto, 143 pontos de amostragens para cada área (A e B), totalizando 286 amostras.

A contagem para aferição da eficácia de controle das plantas daninhas foi feita 14 dias após a aplicação do herbicida pós-emergente e consistiu da contagem de plântulas 
remanescentes na mesma posição da avaliação antes da aplicação herbicida. A eficácia de controle foi baseada na densidade das plantas daninhas sobreviventes ao controle químico.

\subsubsection{Pulverização localizada pós-emergente.}

Os mapas de aplicações localizadas foram baseados na densidade média de infestação das 15 espécies de plantas daninhas avaliadas dentro de cada sub área de 36 $\mathrm{m}^{2}$ (grade de $6 \times 6 \mathrm{~m}$ ), sendo que as mais abundantes foram as plantas daninhas: Commelina benghalensis L., Alternanthera tenella Colla, Leonotis nepetifolia L., Richardia brasiliensis Gomes, Ageratum conyzoides L., Panicum maximum Jacq. e Chamaesyce hirta L. (Figura 33). As demais foram: Phyllanthus corcovadensis Roxb, Digitaria sanguinalis L., Amaranthus viridis L., Ipomoea grandifolia Dammer, Solanum americanum Mill, Emilia sonchifolia L., Conyza bonariensis L. e Sida rhombifolia L.

\section{Área A $\square$ Área B}

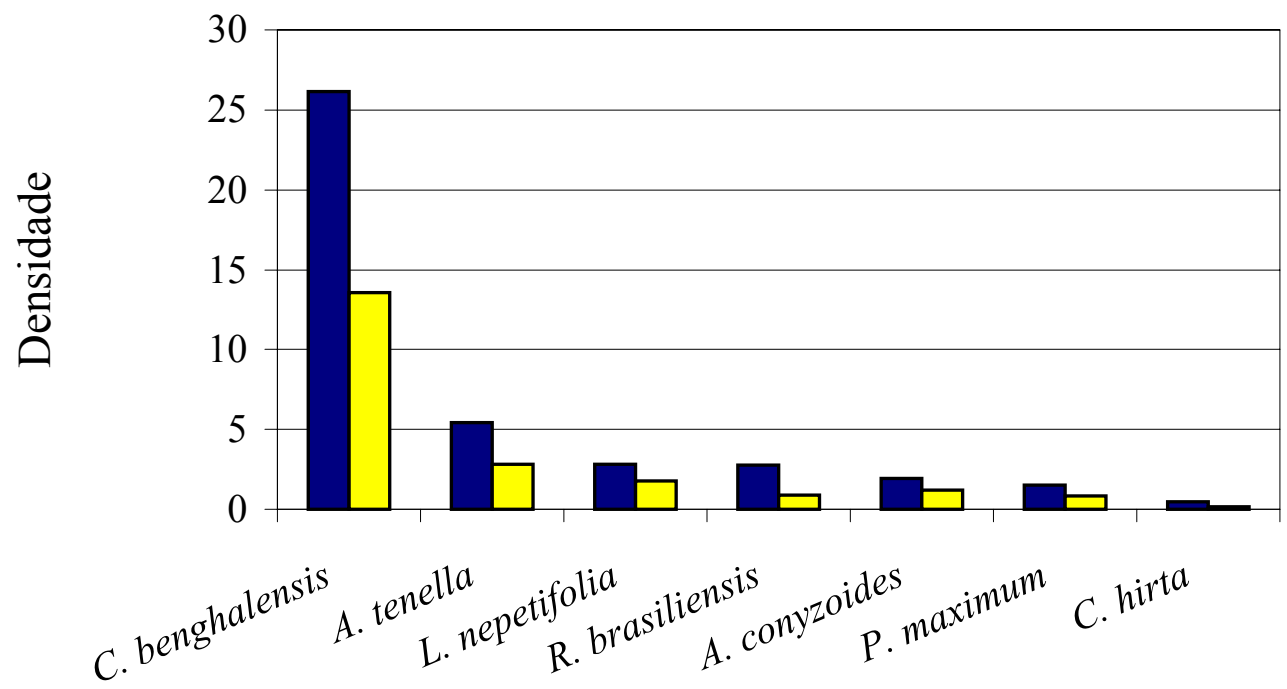

Figura 33 - Densidade média de plantas daninhas por espécie (plantas.m² ${ }^{-2}$. 
A aplicação localizada dos herbicidas foi iniciada às 14 horas, com vento cuja velocidade estava entre 3 a $6 \mathrm{~km} \cdot \mathrm{h}^{-1}$ considerada por Matthews (1992) como "brisa leve", umidade relativa do ar de $80 \%$, temperatura a $25^{\circ} \mathrm{C}$ e terminou às 17 horas. $\mathrm{A}$ pulverização foi feita com consumo de calda de 200 L.ha $^{-1}$, utilizando bicos tipo leque. $\mathrm{O}$ georeferenciamento da pulverização foi feito pelo estaqueamento da área. $\mathrm{O}$ pulverizador utilizado foi um equipamento costal pressurizado com $\mathrm{CO}_{2}$ com uma barra de 2 metros de extensão, dotada de 4 bicos, espaçados de 0,5 m entre si.

Na pulverização localizada, baseada no mapa gerado pelo mapeamento das plantas daninhas, foram utilizadas duas doses de herbicida, as escolhas das doses foram baseadas nas doses mínimas e máximas recomendadas comercialmente da mistura formulada de fluazifop butyl (125 g.L $\left.\mathrm{L}^{-1}\right)$ e fomesafen (125 g.L $\left.\mathrm{L}^{-1}\right)$. Ou seja, com a menor densidade de infestação de plantas daninhas foi utilizada a dose mínima (Dose 1) e maior densidade dose máxima (Dose 2). A relação das doses com os índices de infestação pode ser vista na Tabela 11 .

Tabela 11. Doses dos herbicidas utilizados na aplicação localizada.

\footnotetext{
Dose da mistura formulada dos herbicidas (L.ha $\left.{ }^{-1}\right)^{*} \quad$ Infestação (plantas.m ${ }^{-2}$ )

1 (125g.ha ${ }^{-1}$ de fomesafen $+62,5 \mathrm{~g} \cdot \mathrm{ha}^{-1}$ de fluazifop butyl) $0-50$

$2\left(250 \mathrm{~g} \cdot \mathrm{ha}^{-1}\right.$ de fomesafen $+125 \mathrm{~g} \cdot \mathrm{ha}^{-1}$ de fluazifop butyl $) \quad 50-190$

* O produto formulado utilizado continha 125 g. $\mathrm{L}^{-1}$ de fluazifop butyl +250 g. $\mathrm{L}^{-1} \mathrm{de}$ fomesafen.

\subsubsection{Pulverização convencional.}

A aplicação herbicida convencional consistiu de uma dose única distribuída uniformemente na área e foi baseada no nível médio de infestação das plantas daninhas presentes, determinando-se uma dosagem média em área total da mesma mistura herbicida usada na aplicação localizada pós-emergente.
} 
As duas áreas onde a aplicação foi convencional, testemunhas A e B (TA e TB), também de $0,5 \mathrm{ha}^{-1}$ cada, foram alocadas ao lado de sua respectiva área onde foi realizada a aplicação localizada (Áreas A e B). A amostragem da infestação nestas áreas foi feita pela amostragem no mesmo quadrado de $0,25 \mathrm{~m}^{-2}$, porém em cada área foram feitas 10 subamostras aleatórias na área compondo uma amostra para cada área.

\subsection{Resultados e Discussão}

Todas as plantas daninhas encontradas nas amostragens são consideradas susceptíveis à mistura formulada de fluazifop butyl + fomesafen (Rodrigues \& Almeida, 1998). As duas doses aplicadas são recomendadas pelo fabricante dos herbicidas utilizados (Lorenzi, 2000).

$\mathrm{Na}$ aplicação convencional com dose uniforme em área total nas duas áreas vizinhas às áreas onde foram feitas as aplicações localizadas, foi encontrada uma infestação média de 70 plantas. $\mathrm{m}^{-2}$ para a área TA e 53 plantas.m ${ }^{-2}$ para a área TB. Através do levantamento foi decidida a aplicação da dose de $125 \mathrm{~g} \cdot \mathrm{ha}^{-1}$ do herbicida fluazifop butyl $+250 \mathrm{~g} \cdot \mathrm{ha}^{-1}$ de fomesafen $\left(2 \mathrm{~L} \cdot \mathrm{ha}^{-1}\right.$ da mistura formulada $)$ em área total.

Nas áreas onde foram feitas as aplicações localizadas de herbicida, foi obtida para a área A uma proporção de $62,2 \%$ de células $(6 \times 6 \mathrm{~m})$ com uma densidade entre 0 a 50 plantas.m $\mathrm{m}^{-2}$, onde foi utilizada a dose de $1,0 \mathrm{~L} . h a^{-1}$ da mistura e $37,8 \%$ com 50 a 189 plantas.m $\mathrm{m}^{-2}$ onde foi utilizada a dose igual à aplicação convencional de 2,0 L.ha ${ }^{-1}$ da mistura herbicida formulada (Figura $34-1$ ). 
1)

Flora emergente - Área A - Antes da aplicação do herbicida

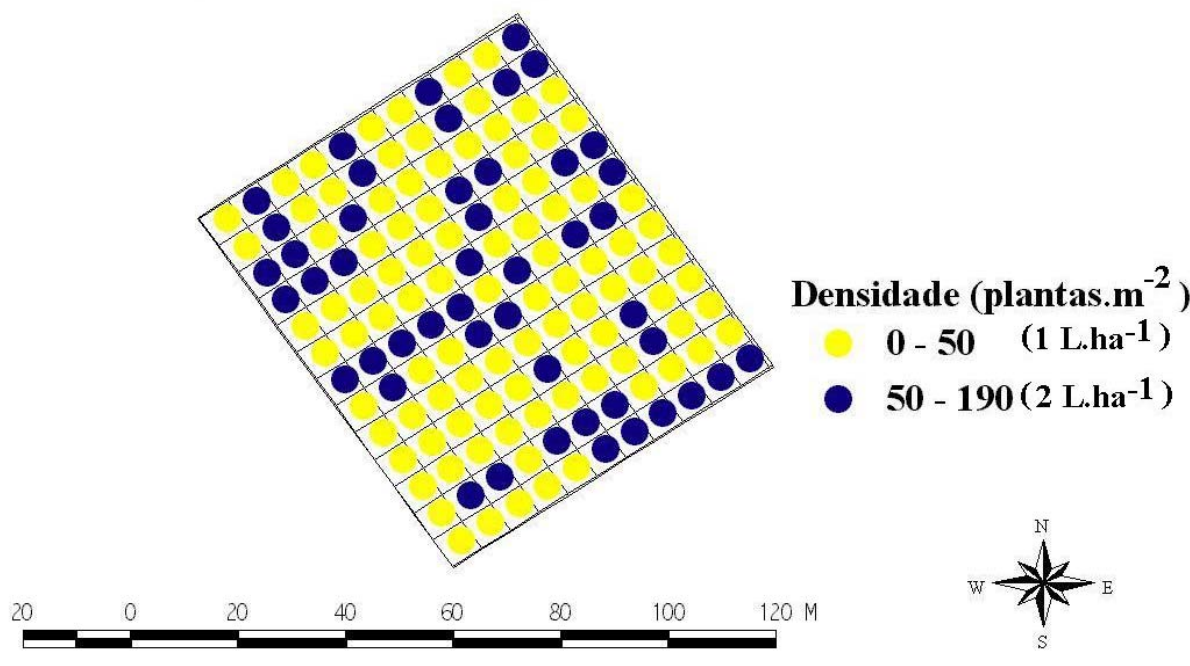

2)

Flora emergente - Área A - Após a aplicação do herbicida

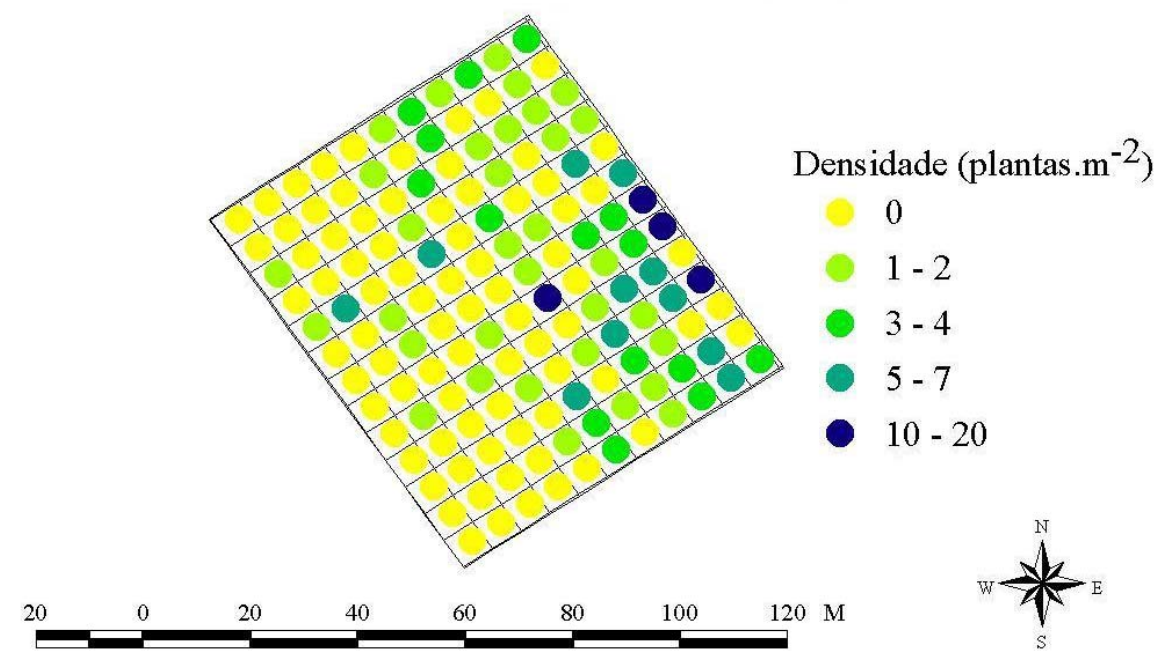

Figura 34 - Mapas de densidade da flora emergente das plantas daninhas na área $\mathrm{A}$ antes (1) e após (2) a aplicação localizada de herbicida. 
Comparando a aplicação localizada com uma aplicação em área total na dose de 2L.ha ${ }^{-1}$ foi obtida uma economia de $18 \%$ da mistura herbicida pós-emergente utilizada (Tabela 12). Trabalhos feitos anteriormente já relataram economias variando de 19 a 89\% (Nordmeyer et al. 1997; Heisel et al., 1997; Christensen et al. 1999a).

Tabela 12. Total de produto herbicida aplicado na área experimental A utilizando aplicação localizada e convencional de herbicidas.

\begin{tabular}{ccccc}
\hline Área A & $\begin{array}{c}\text { Área } \\
(\%)\end{array}$ & Dose & $\begin{array}{c}\text { Quantidade de herbicida aplicado } \\
(\mathrm{L})\end{array}$ & Total \\
\hline Aplicação localizada & 37,8 & 1 & 0,19 & \\
& 62,2 & 2 & 0,64 & 0,83 \\
& & & 1,02 & 1,02 \\
\hline
\end{tabular}

Analisando a eficácia de controle percebeu-se que houve um controle químico satisfatório para a área A com $56 \%$ da área com controle de $100 \%$. Sendo as demais áreas divididas em diferentes proporções de infestação da área dependendo da densidade (Tabela 13).

Tabela 13. Proporção de infestação da área A dependendo da densidade de plantas.

\begin{tabular}{cc}
\hline $\left.\begin{array}{c}\text { Classes de densidade } \\
(\text { Plantas.m }\end{array}\right)$ & $\begin{array}{c}\text { Proporção da área total } \\
(\%)\end{array}$ \\
\hline 0 & 56 \\
$1-2$ & 23 \\
$3-4$ & 11 \\
$5-7$ & 8 \\
$10-20$ & 2 \\
\hline
\end{tabular}


$\mathrm{Na}$ área $\mathrm{B}$ foi constatado que $88,1 \%$ da área estava com uma densidade de plantas variando de 0 a 50 plantas. $\mathrm{m}^{-2}$ e $11,9 \%$ variando de 50 a 171 plantas.m ${ }^{-2}$ (Figura 35). Nesta área foi economizado $44 \%$ de produto com a realização da aplicação localizada em relação à aplicação de 2 L.ha $^{-1}$ da mistura em aplicação convencional em área total (Tabela 14 e 15), demonstrando que a técnica tem muito a contribuir com a melhoria da eficiência dos métodos de controle das plantas daninhas possibilitando uma melhor aplicação de produtos herbicidas no alvo.

Tabela 14. Total de produto herbicida aplicado na área experimental B utilizando aplicação localizada e convencional de herbicidas.

\begin{tabular}{ccccc}
\hline Área B & $\begin{array}{c}\text { Área } \\
(\%)\end{array}$ & Dose & $\begin{array}{c}\text { Quantidade de herbicida aplicado } \\
(\mathrm{L})\end{array}$ & Total \\
\hline Aplicação localizada & 88,1 & 1 & 0,45 & \\
& 11,9 & 2 & 0,12 & 0,57 \\
Aplicação convencional & 100 & 2 & 1,02 & 1,02 \\
\hline
\end{tabular}

Pode se perceber que tanto na área $\mathrm{A}$ quanto na $\mathrm{B}$ a maioria das células com densidade de plantas daninhas remanescentes não coincidiram espacialmente com as células que apresentaram uma densidade maior que 50 plantas. $\mathrm{m}^{-2}$, mostrando que a pulverização herbicida foi adequada, pois inúmeras células com densidades altas de plantas daninhas antes da aplicação tiveram sua densidade reduzida a zero. Portanto as plantas não controladas podem ter tido outro fator de interferência, já que as condições climáticas durante a aplicação e de equipamentos utilizados para pulverização foram ideais. 
1)

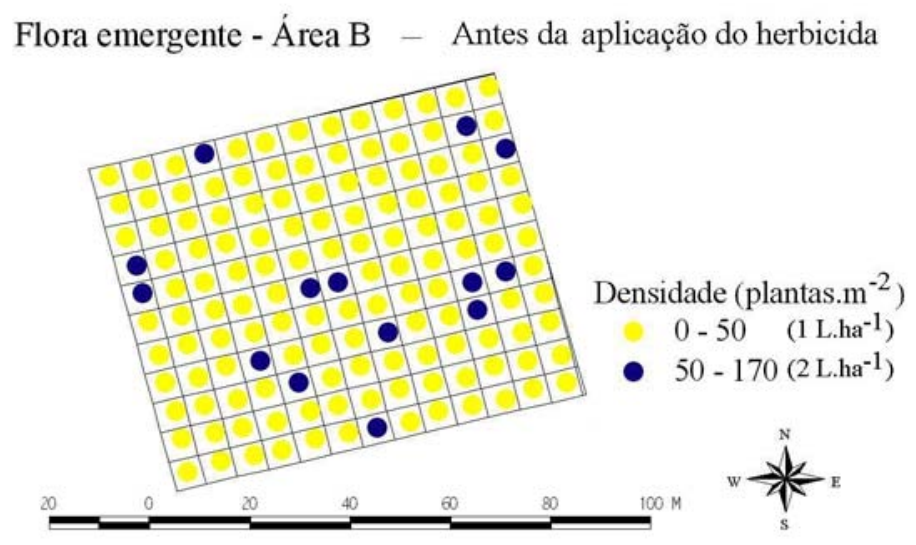

2)

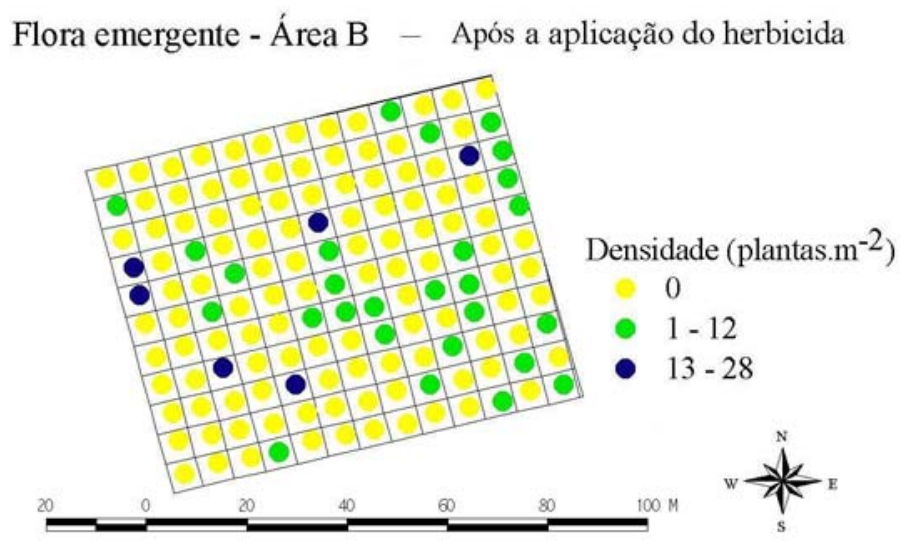

Figura 35 - Mapas de densidade da flora emergente das plantas daninhas na área B antes (1) e após (2) a aplicação localizada pós-emergente.

Tabela 15. Proporção de infestação da área B dependendo da densidade de plantas.

\begin{tabular}{|c|c|}
\hline $\begin{array}{c}\text { Classes de densidade } \\
\left.\text { (Plantas. } \mathrm{m}^{-2}\right)\end{array}$ & $\begin{array}{c}\text { Proporção da área total } \\
\qquad(\%)\end{array}$ \\
\hline 0 & 77 \\
\hline $1-6$ & 19 \\
\hline $7-14$ & 4 \\
\hline
\end{tabular}


$\mathrm{Na}$ avaliação de eficácia e seletividade para todas as áreas em estudo, segundo escala da Sociedade Brasileira da Ciência das Plantas Daninhas - SBCPD (1995), o controle foi considerado eficaz, sendo as notas atribuídas visualizadas na Tabela 16. As densidades médias após aplicação herbicidas nas áreas de aplicação convencional (TA e TB) foram baixas, com uma densidade média de 0,02 plantas.m $^{-2}$ para TA e de 0,11 plantas. $\mathrm{m}^{-2}$ para TB.

Tabela 16. Avaliação da eficácia e seletividade herbicida do experimento.

\begin{tabular}{ll}
\hline \multicolumn{1}{c}{ Áreas pulverizadas } & Notas (SBCPD, 1995) \\
\hline Área A - Aplicação localizada & $\mathrm{Aa}$ \\
Área TA - Aplicação convencional & $\mathrm{Ba}$ \\
Área B - Aplicação localizada & $\mathrm{Aa}$ \\
Área TB - Aplicação convencional & $\mathrm{Aa}$ \\
\hline
\end{tabular}

Neste experimento a aplicação localizada de herbicidas teve um potencial muito grande de economia de produto herbicida nas duas áreas estudadas, variando de $18 \%$ na área $\mathrm{A}$ e $44 \%$ na área B. A eficácia de controle foi considerada boa, pois a população foi reduzida drasticamente com o controle químico utilizado, mesmo em altas infestações como na área experimental A. Portanto a adoção de técnicas que otimizem a aplicação herbicida, aumentando sua eficácia são necessárias em sistemas de produção agrícolas já que equipamentos modernos estão disponíveis e métodos de mapeamento sendo testados, promovendo, conseqüentemente, uma redução de custos e menor poluição ambiental.

\subsection{Conclusões}

A eficácia de controle das plantas daninhas através da aplicação localizada de herbicidas pós-emergentes baseada na variabilidade espacial da comunidade de plantas 
daninhas foi semelhante à aplicação convencional em área total. A aplicação localizada de herbicidas resultou em economias da ordem de 18 e 44\% quando comparada com aplicação convencional em área total baseada na infestação média.

A conclusão principal desta pesquisa foi de que a aplicação localizada de herbicidas tem um grande potencial de redução da utilização de herbicidas onde estes não são necessários, conseqüentemente diminuindo os danos ambientais e aumentando a economicidade da aplicação de herbicidas na agricultura. 


\section{APLICAÇÃO LOCALIZADA DE HERBICIDAS EM PRÉ-EMERGÊNCIA BASEADA EM MAPAS DE BANCO DE SEMENTES}

\section{Resumo}

O objetivo deste trabalho foi de avaliar a eficiência e economicidade da aplicação localizada de herbicida pré-emergente baseada em mapas de tratamentos confeccionados a partir do mapeamento da distribuição espacial do banco de sementes. Para o mapeamento do banco de sementes o solo foi coletado após a colheita do milho e antes do plantio da cultura da soja em março de 2000. Esta área vinha sendo cultivada sob o sistema de plantio direto desde 1998 com a cultura de milho. A coleta do solo foi georeferenciada por um DGPS utilizando uma grade amostral de 20 x 20 m, onde foram coletadas 94 amostras de solo na profundidade de $0-5 \mathrm{~cm}$. A determinação da densidade de sementes das plantas alvo do herbicida aplicado foi obtida pelo método da emergência de plântulas em casa de vegetação. As densidades de sementes do banco de sementes georeferenciadas foram interpoladas utilizando o inverso da distância ao quadrado, servindo de base para a confecção dos mapas de aplicação. A aplicação localizada do herbicida foi realizada na cultura de soja plantada em março de 2001. Foi obtida uma economia de $22 \%$ do produto comercial comparado com a pulverização convencional, sendo a eficiência de controle considerada para as plantas alvos maior que 95\%. Portanto, é perfeitamente possível a aplicação localizada de herbicidas préemergentes baseado no banco de sementes das plantas daninhas com a utilização de ferramentas da agricultura de precisão. Do ponto de vista econômico e ambiental este tipo de racionalização torna-se cada vez mais necessária. 


\section{PATCH WEED CONTROL WITH PREPLANT HERBICIDES BASED ON WEED SEED BANK MAPS}

\section{Summary}

The objective of this research was to evaluate the efficacy and the potential of saving pre herbicides in a crop field, based on a treatment map constructed according to the weed seed bank spatial variability. Soil sampling for the weed seed bank mapping was done after corn harvest and before soybean planting in no till systems. The navigation was geo referenced by a DGPS system within a 20 by $20 \mathrm{~m}$ grid, where it was collected 94 soil cores at 0-5 cm depth. Seed bank density determination was done by seedling counting method in greenhouse conditions. The data was interpolated using the inverse distance to the second power. The weed seed banks were the base for confection of the pre emergence herbicide treatment map, which was.sprayed in march 2001. It was observed $22 \%$ of preplant herbicide saving compared to the broadcast application, and the pre emergence herbicide efficacy was considered excellent for the target weeds ( $>95 \%$ control). It was concluded that it is possible to apply pre emergence herbicide only where just where it is needed, based on weed seed bank. This application can be done by patch weed control technology, using precision farming tools. For both economic and environmental purposes this king of saving will be more and more important in the near future.

\subsection{Introdução}

A necessidade de racionalizar o uso de insumos agrícolas é um desafio constante na agricultura atual. Dentre estes estão os defensivos agrícolas, que cada vez mais se tornam um problema não só econômico como ambiental. Segundo o Sindicato nacional da indústria de produtos para a defesa agrícola (2001) os herbicidas representam $48 \%$ do 
volume total econômico de defensivos comercializados de janeiro à dezembro de 2000, totalizando um montante de US\$ 1,11 bilhões.

Dentro deste cenário a utilização e desenvolvimento de novas tecnologias, como a agricultura de precisão, se tornam necessários. O Conselho Nacional de Pesquisa dos Estados Unidos definiu a agricultura de precisão como um manejo estratégico que usa a tecnologia da informação para reunir dados de múltiplas fontes levando a melhor tomada de decisão dentro do sistema de produção agrícola (National Research Council, 1997).

Os agricultores conhecem a variabilidade espacial dos atributos que determinam as doses dentro de suas áreas, porém recomendam todos os insumos baseados na média do talhão. Mas atualmente com a utilização de técnicas da agricultura de precisão já é possível mapear vários atributos, tais como: tipos de solo, química do solo, produtividade, compactação e infestação das plantas daninhas, e em seguida realizar algum tipo de aplicação ou tratamento localizado (Molin, 1997).

O mapeamento das plantas daninhas merece especial atenção, pois economias de 30 a $72 \%$ de herbicidas em áreas agrícolas já foram obtidas na Europa em lavouras de soja (Christensen et al., 1999c). Como em áreas agrícolas os herbicidas podem contribuir em até $25 \%$ do custo total de produção na cultura da soja em plantio direto, $9 \%$ no milho e 6\% no algodão (FNP Consultoria \& Comércio, 2000), esta preocupação em racionalizar o uso de herbicidas é muito relevante. O presente ensaio avalia a potencialidade de economia de herbicida, baseada em mapas de tratamentos, confeccionados a partir de mapeamentos do banco de sementes das plantas daninhas, gerados por ferramentas usadas rotineiramente na agricultura de precisão.

\subsection{Material e Métodos}

A área do ensaio está localizada no campus da Faculdade de Zootecnia e Engenharia de Alimentos da Universidade de São Paulo e faz parte da área destinada à produção de grãos. Vinha sendo cultivada em plantio direto desde 1998 em um pivô central de 78 ha. 
Após a colheita do milho em maio de 2000, amostragem de solo foi feita dentro de uma grade regular de $20 \times 20 \mathrm{~m}$ com um trado de $7,5 \mathrm{~cm}$ de diâmetro a $5 \mathrm{~cm}$ de profundidade. Todos os pontos foram georeferenciados com um GPS com correção diferencial via satélite. No total foram coletadas 94 amostras de solo em uma área experimental de 3,76 ha.

A determinação do banco de sementes foi feita pela emergência das sementes não dormentes viáveis em casa de vegetação descrita e utilizada por diversos autores (Wilson et al., 1985, Ball \& Miller, 1989; Forcella, 1992; Cardina et al, 1996). Para isto as amostras foram transferidas para vasos individuais e submetidas a um ambiente controlado, onde foi possível fornecer todas condições para que se pudesse obter o máximo de emergência de plântulas. Estas foram contadas e arrancadas do vaso durante um período de 90 dias (Agosto a Novembro de 2000), não foram contadas as sementes que não emergiram durante o período nas amostras. Pela densidade de plântulas emergidas durante todo o período foi calculada a densidade de sementes.ha ${ }^{-1}$.

Baseado nos mapas gerados da densidade de sementes das plantas daninhas foi confeccionado em um software de sistema de informação geográfica, denominado SSToolbox/SST um mapa de tratamento herbicida específico para aplicação préemergente, na cultura da soja plantada em março de 2001, levando em consideração somente as plantas daninhas alvo do herbicida. Os dados foram interpolados pelo método do inverso da distância ao quadrado e foram criadas zonas de segurança ("buffers”) de 2 m para os polígonos gerados. Baseado no mapa de aplicação optou-se pela aplicação de duas doses diferentes do produto.

O herbicida utilizado foi trifluralin $\left(450\right.$ g. $\left.\mathrm{L}^{-1}\right)$ formulado especificamente para aplicação pré-emergente em áreas de plantio direto. A aplicação localizada foi feita com pulverizador convencional com barra de aplicação de $12 \mathrm{~m}$, utilizando 24 bicos tipo leque, calda de 300L.ha-1 com uma dose de 2,5 L.ha' ${ }^{-1}$ do produto comercial.

Primeiramente foi feita uma aplicação convencional (uniforme) em toda área experimental, logo em seguida foi feito um repasse utilizando a mesma dose abrindo e fechando a calda herbicida apenas nos locais do mapa de aplicação com alta densidade de sementes das plantas daninhas. Sendo que no final existiam duas situações: (i) Zonas 
de alta densidade de sementes com uma aplicação herbicida de 5 L.ha $^{-1}$ do produto comercial em áreas com densidade acima de 1700 sementes.m $^{-2}$ e (ii) Zonas com uma densidade de sementes abaixo de 1700 sementes.m ${ }^{-2}$ com uma aplicação de 2,5 L.ha ${ }^{-1}$ do produto comercial.

O mapa de tratamento baseou-se em plantas daninhas susceptíveis ao herbicida utilizado. No experimento os mapas que determinaram a aplicação herbicida foram os mapas de densidade de infestação de capim colonião (Panicum maximum Jacq.), capim colchão (Digitaria sanguinalis L.), apaga-fogo (Alternanthera tenella Colla.) e caruru de mancha (Amaranthus viridis L.).

Foram feitas duas avaliações também na mesma grade de 20 x 20 m no intuito de se comparar a eficiência de aplicação da área convencional com a área onde foi feita a aplicação localizada. As avaliações foram feitas 7 dias após aplicação, com a soja no estádio fenológico V3 e outra no V5 aos 14 dias (Fehr \& Caviness, 1977).

\subsection{Resultados e Discussão}

Foi observada uma distribuição não uniforme, ou seja, contagiosa do banco de sementes, sendo possível a aplicação localizada de herbicidas. A área foi dividida em duas zonas de densidades de sementes.m ${ }^{-2}$. Uma zona acima de 1700 sementes.m $^{-2}$, que representaram 55\% da área experimental e zonas abaixo de 1700 sementes.m ${ }^{-2}$, os $45 \%$ restantes (Figura 36 e 37).

Durante a aplicação localizada, devido às condições operacionais, foram utilizados 9,8 L de produto comercial, ou seja, doses de 2,6 L.ha ${ }^{-1}$ nas áreas de menor densidade e 4,9 L.ha ${ }^{-1}$ nas zonas de maiores densidades do produto comercial. Ao todo foram gastos 3,9 L.ha ${ }^{-1}$ na área experimental ao invés de se utilizar $5 \mathrm{~L} \mathrm{ha}^{-1}$ como foi aplicado na área testemunha ao lado com aplicação convencional uniforme. Portanto, obteve-se uma economia de $22 \%$ em produto herbicida aplicado, semelhante a Nordmeyer et.al, (1997). 


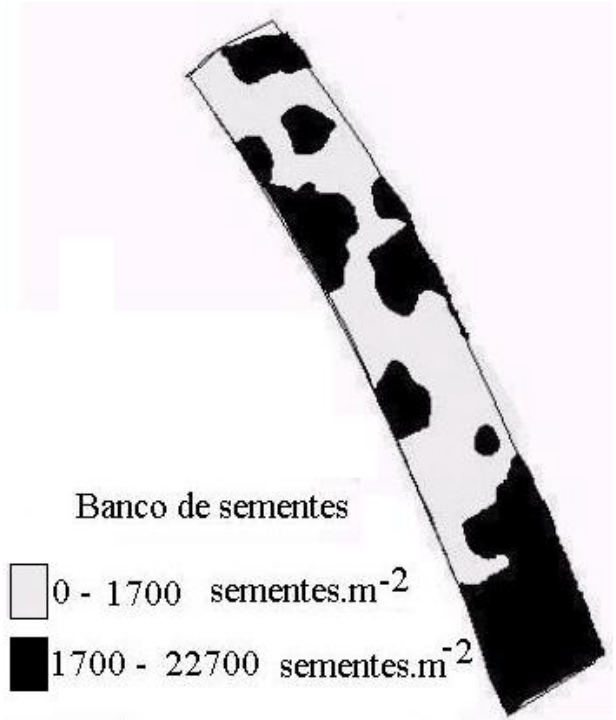

Figura 36 - Mapa do banco de semente

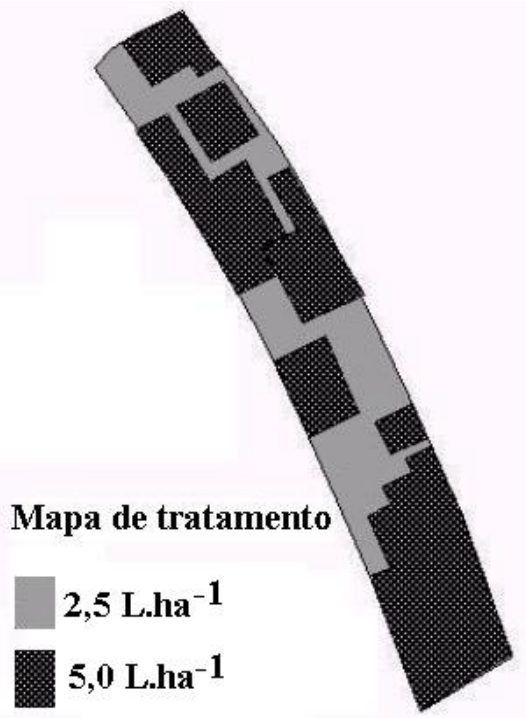

Figura 37 - Mapa de tratamento herbicida.

Quanto à eficiência obteve-se mais de $95 \%$ de controle, sendo até irrelevante a confecção do mapa de plantas emergidas após aplicação, pois foram contadas somente 30 plantas alvo em 94 amostras aos 14 dias ou no estádio fenológico V5 da soja em toda área de 3,76 hectares. Analisando a eficácia e seletividade segundo escala da Sociedade Brasileira da Ciência das Plantas Daninhas (1995) tanto a área aplicada quanto a testemunha ao lado obtiveram o conceito Aa.

O mapa de aplicação confeccionado apresentou alguns problemas operacionais durante a aplicação, tais como, a sobreposição de faixas de aplicação decorrente de falhas na confecção do mapa de tratamento. Estas falhas foram devido ao dimensionamento somente em relação à largura total da barra sem considerar o ajuste às linhas de plantio, pois não era esperada a emergência da cultura no dia da aplicação já que o produto deve ser aplicado em pré-emergência.

Equipamentos e máquinas já estão disponíveis pelas indústrias, sendo essenciais para aplicações localizadas a utilização destes recursos que com certeza diminuiriam os erros operacionais ocorridos neste experimento.

A metodologia usada foi eficiente para a experimentação, porém, em áreas comerciais devem ser utilizados outros equipamentos. A metodologia de determinação do banco de sementes utilizada foi apropriada na ocasião, porém mais estudos básicos 
devem ser feitos para entender melhor os fatores que podem influenciar esta quantificação do banco de sementes e sua emergência em áreas agrícolas, tais como: dormência, emergência e sobrevivência de sementes, da mesma forma que ressaltou Cardina et al. (1996). Além de custos de levantamento e determinação do banco de sementes como ressalta Wiles \& Schweizer (1999).

\subsection{Conclusões}

É possível realizar aplicações localizadas de herbicidas pré-emergentes considerando a variabilidade espacial do banco de sementes de plantas daninhas com a utilização de equipamentos de agricultura de precisão, conseguindo consideráveis economias de herbicidas, e com isso diminuir o impacto ambiental. Porém, mais estudos devem ser feitos para melhor embasamento da aplicação localizada de herbicidas principalmente em relação à: (i) métodos de mapeamento, (ii) tamanho ideal de grade para levantamento, (iii) determinação do banco de sementes, (iv) estabilidade temporal deste banco de sementes na área agrícola e (v) modelagem de infestações futuras. 


\section{CONCLUSÕES GERAIS}

É possível através do mapeamento da variabilidade espacial da flora emergente das plantas daninhas fazer um manejo localizado das plantas daninhas em pósemergência de forma mais racional; sendo a aplicação localizada de herbicidas pósemergentes uma técnica com potencial de controle das plantas daninhas com eficácia semelhante à aplicação em área total.

O mapeamento da variabilidade espacial do banco de sementes pode servir de base para previsões futuras de infestações da flora emergente, pois existiu correlação positiva entre o banco de sementes e a flora emergente, demonstrando que existe um certo grau de estabilidade temporal do banco de sementes dentro da área agrícola. Este fenômeno possibilita o planejamento estratégico de se delinear áreas onde se prevê uma maior infestação das plantas daninhas ao longo do tempo.

O mapeamento da distribuição espacial do banco de sementes pode ser utilizado para a confecção de mapas de aplicação herbicida pré-emergente. Porém novas ferramentas e metodologias mais práticas devem ser desenvolvidas para tornar a determinação do banco de sementes precisa e possível de utilização em larga escala.

O mapeamento das plantas daninhas durante a operação de colheita apresentou algumas imprecisões quando comparado ao mapeamento em grade; porém, tem grande potencial de uso na agricultura de forma extensiva, devido à facilidade de execução, desde que novas pesquisas sejam desenvolvidas para facilitar a operacionalização desta metodologia.

Foi observada uma grande dificuldade de realização prática de alguns métodos de mapeamento, sendo necessário o aprimoramento destas técnicas para que sua completa viabilização seja possível. 
Portanto, antes da completa adoção desta técnica, mais estudos científicos básicos devem ser realizados, principalmente em relação à dinâmica de populações das plantas daninhas e suas correlações com outras variáveis (fertilidade, umidade, produtividade, etc.) considerando o comportamento espacial e temporal. 


\section{REFERÊNCIAS BIBLIOGRÁFICAS}

ANTUNIASSI, U.R. Agricultura de precisão: aplicação localizada de herbicidas. In: CONGRESSO BRASILEIRO DA CIÊNCIA DAS PLANTAS DANINHAS 22. , Foz do Iguaçu, 2000. Anais. Londrina: SBCPD, 2000. p.25-43.

ANTUNIASSI, U.R.; GADANHA JUNIOR, C.D. Aplicação localizada de produtos fitossanitários. In: BORÉM, A.; GIÚDICE, M.P.; QUEIRÓZ, D.M.; MANTOVANI, E.C.; FERREIRA, L.R.; VALLE, F.X.R.; GOMIDE, R.L. (Ed.) Agricultura de precisão. Viçosa: Giúdice \& Borén, 2000. p.181-202.

BALL, D.A. Weed seedbank response to tillage, herbicides, and crop rotation sequence. Weed Science, v.40, p.654-659, 1992.

BALL, D.A.; MILLER S.D. A comparison of techniques for estimation of arable soil seed banks and their relationship with weed flora. Weed Research., v.29, p.365-373, 1989.

BARBERI, P.; COZZANI, A.; MACCHIA, M.; BONARI, E. Size and composition of the weed seed bank under different management systems for continuous maize cropping. Weed Research, v.38, p.319-334, 1998.

BARBOUR, L.G.; BURK; J.H.; PITTS, W.D. Terrestrial plant ecology. Menlo Park: The Benjamim/Cummings Pub., 1987. 634p.

BENOIT, B.L. ; KENKEL, N.C.; CAVERS, P.B. Factors influencing the precision of soil seed bank estimates. Canadian Journal of Botany, v.67, p.2833-2840, 1989.

CARDINA, J.; JOHNSON, G.A.; SPARROW, D.H. The nature and consequence of weed spatial distribution. Weed Science, v.45, n.3, p.364-373, 1997.

CARDINA, J.; SPARROW, D.H. A comparison of methods to predict weed seedling populations from the soil seed bank. Weed Science, v. 44, p.46-51, 1996. 
CARDINA, J.; SPARROW, D.H; Mc COY, E.L. Analysis of spatial distribution of Common Lambsquarters (Chenopodium album) in no-till soybean (Glycine max). Weed Science, v.43, p.258-268, 1995.

CARDINA, J.; SPARROW, D.H; Mc COY, E.L. Spatial relationships between seed bank and seedling populations of common lambsquarter (Chenopodium album) and annual grasses. Weed Science, v.44, p.298-308, 1996.

CARMONA, R. Problemática e manejo de banco de sementes de invasoras em solos agrícolas. Planta Daninha, v. 10, n. 1/2, p. 5-16, 1992.

CHRISTENSEN, S.; HEISEL, T.; BENLLOCH, J.V. Patch spraying and rational weed mapping in cereals. In: THE INTERNATIONAL CONFERENCE ON PRECISION AGRICUlturE, 4., Minneapolis, 1999. Proceedings. Wisconsin: ASA, CSSA, SSSA, 1999a. p.773-785.

CHRISTENSEN, S.; HEISEL, T.; PAICE, M. Simulation of long term Alopecurus myosuroides population using three patch spraying strategies. In: THE EUROPEAN CONFERENCE ON PRECISION AGRICULTURE, 2., Odense, 1999. Shefield: Shefield Academic, 1999b. p.977-987.

CHRISTENSEN,S.; WALTER,A.M.; HEISEL,T. The patch treatment of weeds in cereals. In: THE 1999 BRIGHTON CONFERENCE - WEEDS, Brighton, 1999a. Proceedings. Brighton: BCPC, 1999c. p.591-600.

CHRISTOFFOLETI, P.J.; CAETANO, R.S.X. Soil seed banks. Scientia Agricola, v.55, n.esp, p. 74-78, 1998.

CLAY, S.; JOHNSON, G. Scouting for weeds. http://www.ppi-far.org/ssmg (06 set. 2001).

COLLIVER, C.T.; MAXWELL, B.D.; TYLER, D.A.; ROBERTS, D.W.; LONG, D.S. Georeferencing wild oat infestations in small grains: Accuracy and efficiency of three weed survey techniques. In: INTERNATIONAL CONFERENCE ON PRECISION AGRICUlturE, 3., Minneapolis, 1996. Proceedings. Wisconsin: ASA, CSS, SSSA, 1996. p.453-463. 
CRESSIE, N. Statistics for spatial data. New York: John Wiley, 1991, 900p.

DANA, P.H. Global positioning system overview.

http://www.colorado.edu/geography/gcraft/notes/gps/gps f.html (05 out. 2001).

DESSAINT, F.; CHADOEUF, R.; BARRALIS, G. Spatial pattern analysis of weed seeds in the cultivated soil seed bank. Journal of Applied Ecology, v. 28, p. 721$730,1991$.

DIELEMAN, J.A.; MORTENSEN, D.A. Characterizing the spatial pattern of Abutilon theophrasti seedling patches. Weed Research, v.39, p.455-467, 1999.

EBERLEIN, C.V.; KING, B.A.; GUTTIERI, M.J. Weed management with site-specific herbigation. ln: INTERNATIONAL CONFERENCE ON PRECISION AGRICUlTURE, 4., Minneapolis, 1999. Proceedings. Wisconsin: ASA, CSSA, SSSA, 1999. p. 869-876.

ENGQVIST, A.; BENGTSSON, P.; ENFALT, P. A model for site-specific broadleaved weed control based on weed plant variables. In: THE EUROPEAN CONFERENCE ON PRECISION AGRICULTURE, 1., Warwick, 1997. Proceedings. Oxford: BIOS Scientific, 1997. p. 869-878.

ESPEBY, L. Germination of weed seeds and competition in stands of weeds and barley influences of mineral nutrients. Crop Production Science, v. 6, p. 1-172, 1989.

FEHR, W.R.; CAVINESS, C.E. Stages of soybean development. Ames: Yowa State University, Cooperative Extension Service, 1977. 11p. (Special Report, 80).

FEYARTS, F.; POLLET, P.; VAN GOOL, L.; WAMBACQ, P. Sensor for weed detection based on spectral measurements. ln: THE INTERNATIONAL CONFERENCE ON PRECISION AGRICULTURE, 4., Minneapolis, 1999. Proceedings. Wisconsin: ASA, CSSA, SSSA, 1999. p.1537-1548.

FNP CONSULTORIA \& COMÉRCIO. AGRIANUAL 2000: anuário da agricultura brasileira. São Paulo: FNP, 2000. 546p. 
FORCELLA, F. Prediction of weed seed densities from buried seed reserves. Weed Research, v.32, p. 29-39, 1992.

GEHARDS, R.; SOKEFELD, M.; TIMMERMANN, C. Results of a four-year study on site-specific herbicide application. In: THE EUROPEAN CONFERENCE OF PRECISION AGRICULTURE, 2., Odense, 1999. Shefield: Shefield Academic Press, 1999. p.689-697.

GERHARDS, R.; WYSE-PESTER, D.Y.; MORTENSEN, D.A. Spatial Stability of weed patches in agricultural fields, In: THE INTERNATIONAL CONFERENCE ON PRECISION AGRICULTURE, 3., Minneapolis, 1999. Proceedings. Wisconsin: ASA, CSSA, SSSA, 1996. p.495-504.

GREEN, H.M.; VENCILL, W.K. Precision management of spatially variable weeds. In: THE EUROPEAN CONFERENCE ON PRECISION AGRICULTURE, 1., Warwick, 1997. Proceedings. Oxford: BIOS Scientific, 1997. p. 983-989.

GROSS, K.L.; RENNER, K.A. A new method for estimating seed numbers in the soil. Weed Science, v.37, p. 836-839, 1989.

HANKS, J.E. Smart sprayer selects weeds for elimination. Agricultural Research, v.44, n.4, p.15, 1996.

HARVEY R G; WAGNER C R. A simple technique for predicting future weed problems. Nutrient and Pest Management Program. Madison: University of Wisconsin, 1992. 3p. (Cooperative Extension Division).

HEISEL, T.; ANDREASEN, C.; ERSBOLL, A.K. Annual weed distributions can be mapped with krigging. Weed Research, v.36, p.325-337, 1996a.

HEISEL, T.; CRISTENSEN, S.; WALTER, A. M. Weed managing model for patch spraying in cereal. $\mathrm{ln}$ : INTERNATIONAL CONFERENCE ON PRECISION AGRICUlTURE, 3., Minneapolis, 1996. Proceedings. Wisconsin: ASA, CSSA, SSSA, 1996b. p.999-1007. 
HEISEL, T.; CHRISTENSEN, S.; WALTER, A.M. Whole field experiments with sitespecific weed management. In: THE EUROPEAN CONFERENCE ON PRECISION AGRICULTURE, 1., Warwick, 1997. Proceedings. Oxford: BIOS Scientific, 1997. p.759-768.

ISAAKS, E.H.; SRIVASTAVA, R.M. An introduction to applied geostatistics. New York: Oxford University Press, 1989. 561p.

JOHNSON, G.A.; MORTENSEN, D.A.; GOTWAY, C.A. Spatial and temporal analysis of weed seedling populations using geostatistics. Weed Science, v.44, p.704-710, 1996.

JOURNEL, A.G. Fundamentals of geostatistics in five lessons. Washington: American Geophysical Union, 1989. 40p.

KROPFF, M.J.; BASTIAANS, L.; COUSENS, R.D. Approaches used in the prediction of weed population's dynamics. In: THE 1999 BRIGHTON CONFERENCE WEEDS, Brighton, 1999a. Proceedings. Brington: BCPC, 1999. p.399-408.

KVIEN, C.K.; BOYDELL, C.D.; POCKNEE,S. Precision management of spatially variable weeds. In: THE EUROPEAN CONFERENCE ON PRECISION AGRICULTURE, 1., Warwick, 1997. Proceedings. Oxford: BIOS Scientific, 1997. p. 983-989.

LASS, L. W.; CALLIHAN, R.H. GPS and GIS for weed surveys and management. Weed Technology, v.7, n.1, p.249 -254, 1993.

LIBARDI, P.L.; PREVEDELlO,C.L.; PAULETTO, E.A.; MORAES, S.O. Variabilidade especial da umidade, textura e densidade de partículas ao longo de uma transeção. Revista Brasileira de Ciência do Solo, v.10, n.2, p.85-90, 1986.

LINDQUIST, J.L.; DIELEMAN, J.A.; MORTENSEN, D.A.; JOHNSON, G.A.; WYSEPESTER, D.Y. Economic importance of managing spatially heterogeneous weed populations. Weed Technology, v.12, n.1, p.7-13, 1998. 
LORENZI, H. Manual de identificação e de controle de plantas daninhas. 5.ed. Nova Odessa: Instituto Plantarum, 2000. 81p.

LUTMAN, P.J.W.; PERRY,N.H. Methods of weed patch detection in cereal crops. In: THE 1999 BRIGHTON CONFERENCE - WEEDS, Brighton, 1999a. Proceedings. Brington: BCPC, 1999. p.627-634.

MANTOVANI, E.C. Agricultura de precisão e sua organização no Brasil. In: BORÉM, A.; GIÚDICE, M.P.; QUEIRÓZ, D.M.; MANTOVANI, E.C.; FERREIRA, L.R.; VALLE, F.X.R.; GOMIDE, R.L. Agricultura de precisão. Viçosa: Giúdice \& Borén, 2000. p.77-92.

MAROIS, J.J. Modeling in precision agriculture. In: BORÉM, A.; GIÚDICE, M.P.; QUEIRÓZ, D.M.; MANTOVANI, E.C.; FERREIRA, L.R.; VALLE, F.X.R.; GOMIDE, R.L. Agricultura de precisão. Viçosa: Giúdice \& Borén, 2000. p.285298.

MARTINS, C. C.; SILVA, W. R. Estudos de bancos de sementes do solo. Informativo ABRATES, v.4, n 1, p.49-56, 1994.

MATTHEWS, G.A. Pesticide application methods.. New York: Longman Scientific Technical, 1992. 405p.

MEDLIN, C.R.; SHAW, D.R. Economic comparison of broadcast and site specific applications in nontransgenic and glyphosate-tolerant Glycine max. Weed Science, v. 48, p. 653-661, 2000.

MOLIN, J.P. Agricultura de precisão. Parte I: O que é o estado da arte em sensoriamento. Engenharia Agrícola., v.17, n.2, p. 109-121, 1997.

MOLIN, J.P. Utilização de GPS em Agricultura de precisão. Engenharia Agrícola, v.17, n.3, p. 121-132, 1998.

MOLIN, J.P. Agricultura de precisão: fundamentos e estado atual da arte. In: CÂMARA, G.M. Soja: Tecnologia da Produção II. Piracicaba: ESALQ, Departamento de Produção Vegetal, 2000. p.423-437. 
NATIONAL OCEANIC AND ATMOSPHERIC ADMINISTRATION. Removal of GPS selective availability (S/A) http://www.ngs.noaa.gov/FGCS/info/sans_SA/ (5 out. 2001).

NATIONAL RESEARCH COUNCIL Precision Agriculture in the $21^{\text {st }}$ century: geospatial and information technologies in crop management. Washington: National Academic Press, 1997. 149p.

NORDMEYER, H.; HAUSTLER, A.; NIEMANN, P. Patchy weed control as an approach in precision farming. In: THE EUROPEAN CONFERENCE ON PRECISION AGRICULTURE, 1., Warwick, 1997. Proceedings. Oxford: BIOS Scientific, 1997. p.307-315

PAICE, M.E.R.; DAY, W.; REW, L.J.; HOWARD, A. A stochastic simulation model for evaluating the concept of patch spraying. Weed Research, v.38, n.5, p.373-388, 1998.

POLLET, P.; FEYARTS, F.; WAMBACQ, P.; VAN GOOL, L.; Weed detection based on structural information using a imaging spectrograph. $\ln$ : THE INTERNATIONAL CONFERENCE ON PRECISION AGRICULTURE, 4., Minneapolis, 1999. Proceedings. Wisconsin: ASA, CSSA, SSSA, 1999. p.15791590.

REW, L.J.; CUSSANS, J.W.; MUGGLESTONE, M.A.; MILLER, P.C.H. A technique for mapping the spatial distribution of Elymus repens with estimates of the potential reduction in herbicides usage from patch spraying. Weed Research, v.36, p.283292, 1996.

RIBEIRO JUNIOR, P.J. Métodos geoestatísticos no estudo da variabilidade especial de parâmetros do solo. Piracicaba, 1995. 99p. (Mestrado) - Escola Superior de Agricultura “Luiz de Queiroz"/Universidade de São Paulo.

RODRIGUES, B.N.; ALMEIDA, F.S. Guia de herbicidas. Londrina: Rodrigues \& Almeida, 1998. 648p. 
SHEARER, S.A.; JONES, P.T. Selective application of post emergence herbicides using photoeletrics. Transactions of the ASAE, v.34, n.4, p.1661-1666, 1991.

SINDICATO NACIONAL DA INDÚSTRIA DE PRODUTOS PARA A DEFESA AGRÍCOLA. Vendas mensais de defensivos agrícolas - dezembro/2000. http://www.sindag.com.br/html/estat_dezembro.html (28 maio 2001).

SOCIEDADE BRASILEIRA DA CIÊNCIA DAS PLANTAS DANINHAS. Procedimentos para a instalação, avaliação e análise de experimentos com herbicidas. Londrina, 1995. 42p.

STAFFORD, J.V.; MILLER, P.C.H. Spatially variable treatment of weed patches. In: INTERNATIONAL CONFERENCE ON PRECISION AGRICULTURE, 3., Minneapolis, 1996. Proceedings. Wisconsin: ASA, CSSA, SSSA, 1996. p.465474.

STAFFORD, J.V.; LeBARS, J.M.; AMBLER, B. A hand held data logger with integral GPS for producing weed maps by field walking. Computers and Electronics in Agriculture, v. 14, n.2/3, p.235-247, 1996.

STEEL, R.G.D.; TORRIE, J.H. Principles and procedures of statistics: A biometrical approach. New York: Mc Graw-Hill, 1980. 633p.

TIAN, L.; REID, J.F.; HUMMEL, J.W. Development of a precision sprayer for sitespecific management. Transactions of the ASAE, v. 42, n.4, p. 893-900, 1999.

TRANGMAR, B.B.; YOST, R.S.; UEHARA, G. Application of geostatistics to spatial studies of soil properties. Advances in Agronomy, v.38, p.45-94, 1985.

VIEIRA, S.R. Geoestatística aplicada à agricultura de precisão. In: BORÉM, A.; GIÚDICE, M.P.; QUEIRÓZ, D.M.; MANTOVANI, E.C.; FERREIRA, L.R.; VALLE, F.X.R.; GOMIDE, R.L. Agricultura de precisão. Viçosa: Giúdice \& Borén, 2000. p.93-108. 
VIEIRA, S.R.; NIELSEN, D.R.; BIGGAR, J.W. Spatial variability of field measured infiltration rate. Soil Science Society American Journal, v.45, p. 1040-1048, 1981.

VIEIRA, S.R.; HATFIELD, J.L.; NIELSEN, D.R.; BIGGAR, J.W. Geostatistical theory and application to variability of some agronomical properties. Hilgardia, v.51, n.3, p.1-85, 1983.

VOLL, E. Agricultura de precisão: Manejo de plantas daninhas. In: BORÉM, A.; GIÚDICE, M.P.; QUEIRÓZ, D.M.; MANTOVANI, E.C.; FERREIRA, L.R.; VALLE, F.X.R.; GOMIDE, R.L. Agricultura de precisão. Viçosa: Giúdice \& Borén, 2000. p.203-235.

VOLL, E.; KARAN, D.; GAZZIEIRO, D.L.P. Dinâmica de populações de trapoeraba (Commelina benghalensis L.) sobre manejo de solos e de herbicidas. Pesquisa Agropecuária Brasileira, v.32, n.6, p.571-578, 1997a.

VOLL, E.; KARAN, D.; GAZZIEIRO, D.L.P. Dinâmica de populações de capim colchão (Digitaria horizontalis Wild.) sobre manejo de solos e de herbicidas. Pesquisa Agropecuária Brasileira, v.32, n.4, p.373-378, 1997 b.

WILES, L.J.; SCHWEIZER, E.E. Mapping weed populations: The cost of counting and identifying seedlings and seeds. In: Madison, 1999. INTERNATIONAL CONFERENCE ON PRECISION AGRICULTURE, 4., Minneapolis, 1999. Proceedings. Wisconsin: ASA, CSSA, SSSA, 1999. p.499-509.

WILLIAMS II, M.M.; GEHARDS, R.; REICHART, S.; MORTENSEN, D.A. Spatiotemporal outcomes of site-specific weed management in maize. In: THE EUROPEAN CONFERENCE OF PRECISION AGRICULTURE, 2., Odense, 1999. Shefield: Shefield Academic Press, 1999a. p.897-906. 
WILLIAMS II, M.M.; GEHARDS, R.; REICHART, S.; MORTENSEN, D.A.; MARTIN, A.R. Weed seedling population responses to a method of site-specific weed management In: INTERNATIONAL CONFERENCE ON PRECISION AGRICULTURE, 4., Minneapolis, 1999. Proceedings. Wisconsin: ASA, CSSA, SSSA, 1999b. p.123-133.

WILSON, R.G.; KERR, E.D.; NELSON, L.A. Potential for using weed seed content in the soil to predict future weed problems. Weed Science, v.33, p. 171-175, 1985.

YENISH, J.P.; DOLL, J.D.; BUHLER, D.D. Effects of tillage on vertical distribution and viability of weed seed in soil. Weed Science, v.40, p.429-433, 1992.

ZANIN, G.; BERTI, A.; RIELLO, L. Incorporation of weed spatial variability into the weed control decision-making process. Weed Research, v.38, n.2, p.107-118, 1998. 